\title{
Long-Term Surveillance Plan FOR THE BODO CANYON DISPOSAL Site, Durango, Colorado
}

\section{November 1995}

\section{DISCLAIMER}

This report was prepared as an account of work sponsored by an agency of the United States Government. Neither the United States Government nor any agency thereof, nor any of their employees, makes any warranty, express or implied, or assumes any legal liability or responsibility for the accuracy, completeness, or usefulness of any information, apparatus, product, or process disclosed, or represents that its use would not infringe privately owned rights. Reference herein to any specific commercial product, process, or service by trade name, trademark, manufacturer, or otherwise does not necessarily constitute or imply its endorsement, recommendation, or favoring by the United States Government or any agency thereof. The views and opinions of authors expressed herein do not necessarily state or reflect those of the United States Government or any agency thereof.

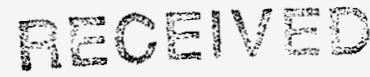

DEC 121995

OSTI 
This report has been reproduced from the best available copy. Available in paper copy and microfiche.

Number of pages in this report: 156

DOE and DOE contractors can obtain copies of this report from:

Office of Scientific and Technical Information

P. O. Box 62

Oak Ridge, TN 37831

(615) 576-8401

This report is publicly available from:

National Technical Informaion Service

Department of Commerce

5285 Port Royal Road

Springfield, VA 22161

(703) $487-4650$ 


\section{DISCLAMMER}

Portions of this document may be illegible in electronic image products. Images are produced from the best available original document. 


\section{LONG-TERM SURVEILLANCE PLAN}

FOR THE BODO CANYON DISPOSAL SITE

DURANGO, COLORADO

November 1995

Prepared for

U.S. Department of Energy

Environmental Restoration Division

UMTRA Project Team

Albuquerque, New Mexico

Prepared by

Jacobs Engineering Group Inc.

Albuquerque, New Mexico 
Section

Page

1.0 INTRODUCTION ........................................................................... $1-1$

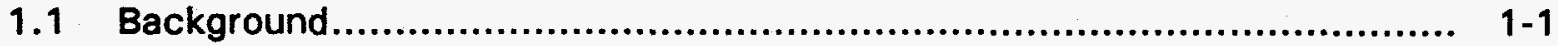

1.2 Licensing process .................................................................. 1-1

1.3 Long-term surveillance plan ................................................... $1-2$

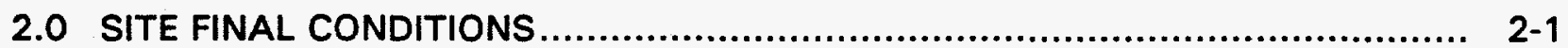

2.1 Processing and disposal site history............................................ $2-1$

2.2 Description and location of the disposal site area .............................. $2-1$

2.3 Disposal site access................................................................. $2-4$

2.4 Disposal cell design ............................................................. $2-4$

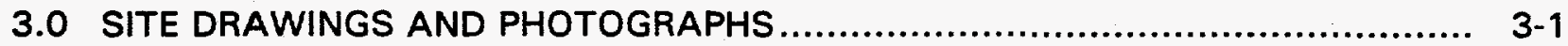

3.1 Disposal site map ..............................................................

3.2 Disposal site as-built drawings ............................................... 3-1

3.3 Site baseline photographs..................................................... $3-2$

3.4 Site aerial photographs........................................................ $3-4$

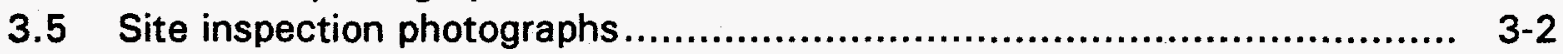

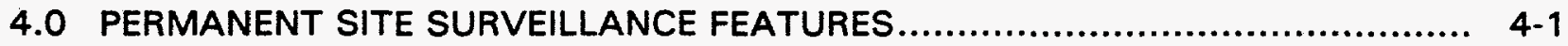

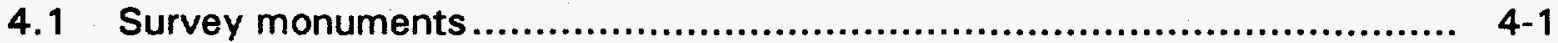

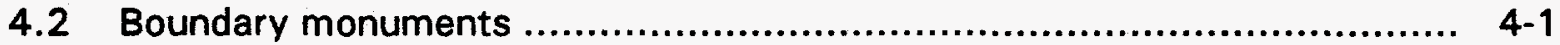

4.3 Site markers .................................................................... 4-1

4.4 Entrance and perimeter signs ................................................... 4-1

4.5 Settlement plates .................................................................. 4-10

4.6 Additional site-surveillance features .......................................... 4-10

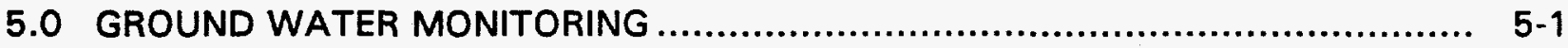

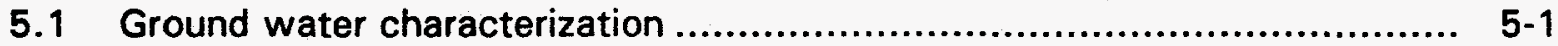

5.1 .1 Hydrostratigraphy ...................................................... $5-1$

5.1 .2 Monitor well network.................................................... 5-7

5.1 .3 Background ground water quality ................................... $5-7$

5.1.4 Hazardous constituents ................................................. 5-9

5.1.5 Concentration limits for hazardous constituents ....................... 5-14

5.2 Ground water protection monitoring plan...................................... 5-14

5.2.1 Direct ground water monitoring network .............................. 5-16

5.2 .2 Sampling frequency ..................................................... 5-16

5.2.3 Screening monitoring and exceedance validation.........................5-16

5.2.4 Evaluative monitoring ................................................... 5-18

5.2 .5 Indirect monitoring.......................................................... 5-18

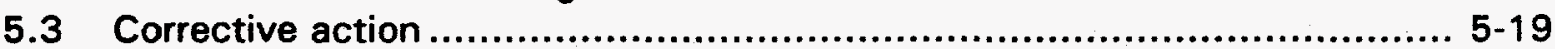

5.4 Data validation and quality assurance ......................................... 5-19

5.5 Reporting ................................................................... 5-19 


\section{TABLE OF CONTENTS (Continued)}

Section

Page

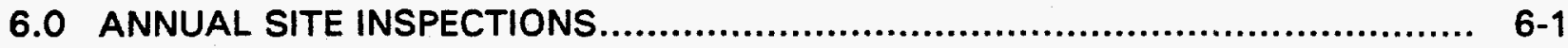

6.1 Inspection frequency............................................................ $6-1$

6.2 Inspection team ................................................................. $6-1$

6.3 Preparation for inspection ...................................................... $6-2$

6.4 Site inspection and inspection checklist ....................................... $6-2$

6.4 .1 Off-site areas .............................................................. $6-3$

6.4 .2 On-site areas.............................................................. $6-3$

6.5 Modifying processes ............................................................. $6-4$

6.6 Vegetation........................................................................ $6-4$

6.6.1 Planned vegetation ...................................................... 6-4

6.6 .2 Volunteer plant growth.................................................... $6-5$

6.7 Site inspection map .......................................................... $6-5$

6.8 Reporting requirements ....................................................... 6

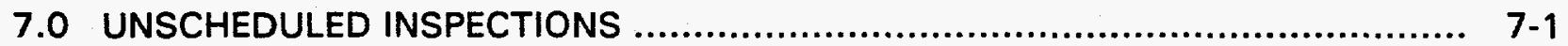

7.1 Follow-up inspections....................................................... $7-1$

7.2 Contingency inspections.....................................................

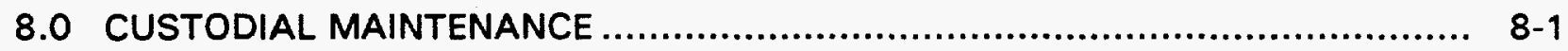

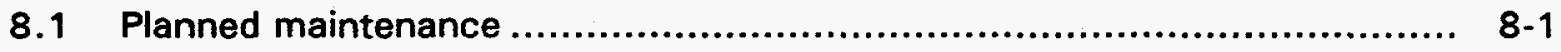

8.2 Unscheduled maintenance or repair ......................................... $8-1$

8.3 Certification and reporting requirements ................................... 8 -2

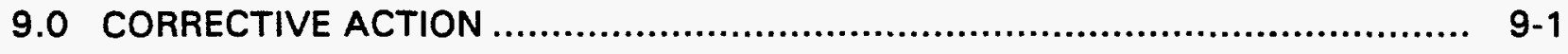

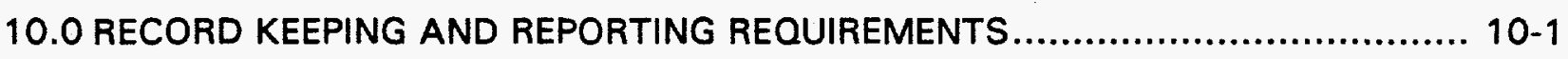

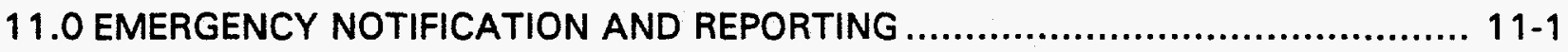

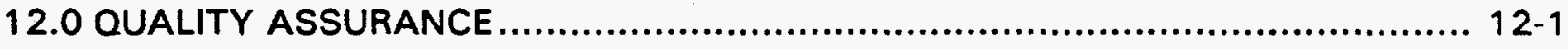

13.0 PERSONNEL HEALTH AND SAFETY ............................................... 13-1

13.1 Emergency medical and law enforcement................................... 13-1

13.2 Reportable incidents ........................................................ 13-2

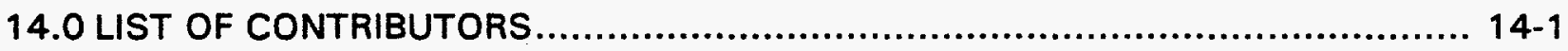

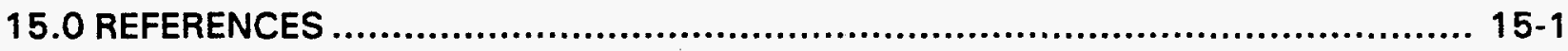


TABLE OF CONTENTS (Concluded)

ATTACHMENT 1 NRC CONCURRENCE AND LICENSING DOCUMENTATION

ATTACHMENT 2 SITE OWNERSHIP/CUSTODY DOCUMENTATION

ATTACHMENT 3 BODO CANYON TOE DRAIN CLOSURE AND HOLDING POND DECOMMISSIONING PLAN

ATTACHMENT 4 BODO CANYON TOE DRAIN POND DISCHARGE PERMIT MANAGEMENT PLAN

ATTACHMENT 5 SITE INSPECTION PHOTO LOG

ATTACHMENT 6 INITIAL SITE INSPECTION CHECKLIST

ATTACHMENT 7 AGENCY NOTIFICATION AGREEMENTS 


\section{LIST OF FIGURES}

Figure

Page

2.1 Location of Bodo Canyon disposal site, La Plata County, Colorado. 2-2

2.2 Bodo Canyon, Colorado, disposal site area map $2-3$

2.3 Plan view of Bodo Canyon, Colorado, disposal cell 2-6

2.4 As-built cross section of cover system, Bodo Canyon, Colorado, disposal cell

2.5 Topslope cover system, Bodo Canyon, Colorado, disposal site

4.1 UMTRA Project survey monument, Bodo Canyon, Colorado, disposal site

4.2 UMTRA Project boundary monument, Bodo Canyon, Colorado, disposal site.

4.3 UMTRA Project entrance site marker (SMK-1), Bodo Canyon, Colorado, disposal site.

4.4 UMTRA Project site marker at crest of disposal cell, Bodo Canyon, Colorado, disposal site

4.5 UMTRA Project site marker incised message, Bodo Canyon, Colorado, disposal site.

4.6 UMTRA Project entrance sign and message, Bodo Canyon, Colorado, disposal site.

4.7 UMTRA Project perimeter sign and message, Bodo Canyon, Colorado, disposal site

4.8 UMTRA Project settlement plate, Bodo Canyon, Colorado, disposal site

5.1 Location of monitor wells and topographic map, Bodo Canyon, Colorado, disposal site.

5.2 Schematic cross section A-A', Bodo Canyon, Colorado, disposal site ............... 5-4

5.3 Schematic cross section B-B', Bodo Canyon, Colorado, disposal site................ 5-5

9.1 Key elements in the corrective action process .................................. $9-2$

\section{LIST OF PLATES}

1 Bodo Canyon disposal site map, Durango, Colorado 


\section{LIST OF TABLES}

Table

Page

2.1 Bodo Canyon, Colorado, disposal site access key holders

3.1 Aerial photography specifications for the Bodo Canyon, Colorado, disposal site.

4.1 Locations of monuments and markers, Bodo Canyon, Colorado, disposal site.

5.1 Monitor wells at the Bodo Canyon, Colorado, disposal site.

5.2 Summary of water quality data for tailings solutions, background ground water, and toe drain effluent, Bodo Canyon, Colorado, disposal site

5.3 Proposed concentration limits for hazardous constituents in tailings solutions, Bodo Canyon, Colorado, disposal site.

5.4 Parameters to be measured during screening monitoring at the Bodo Canyon, Colorado, disposal site 


\section{LIST OF ACRONYMS}

Acronum

BMT

CDOW

CDPHE

DOE

DQO

EPA

ES\&H

GJPO

LTSP

$M C L$

MSL

NRC

NWS

PMP

POC

QA

QC

RAC

RAP

RRM

SM

SMK

SOP

SOW

TAC

UMTRA

UMTRCA

UPDCC

USGS

VCA

\section{Definition}

boundary monument

Colorado Division of Wildlife

Colorado Department of Public Health and Environment

U.S. Department of Energy

data quality objective

U.S. Environmental Protection Agency

environment, safety and health

Grand Junction Projects Office

long-term surveillance plan

maximum concentration limit

mean sea level

U.S. Nuclear Regulatory Commission

National Weather Service

probable maximum precipitation

point of compliance

quality assurance

quality control

remedial action contractor

remedial action plan

residual radioactive material

survey monument

site marker

standard operating procedure

statement of work

Technical Assistance Contractor

Uranium Mill Tailings Remedial Action

Uranium Mill Tailings Radiation Control Act

UMTRA Project Document Control Center

U.S. Geological Survey

Vanadium Corporation of America 


\subsection{INTRODUCTION}

This long-term surveillance plan (LTSP) for the Uranium Mill Tailings Remedial Action (UMTRA) Project Bodo Canyon disposal site at Durango, Colorado, describes the surveillance activities for the disposal site. The U.S. Department of Energy (DOE) will carry out these activities to ensure that the disposal cell continues to function as designed. This LTSP was prepared as a requirement for DOE acceptance under the U.S. Nuclear Regulatory Commission (NRC) general license for custody and long-term care of residual radioactive materials (RRM) from processing uranium ore. This LTSP documents that the land and interests are owned by the United States and details how long-term care of the disposal site will be carried out. It is based on the DOE's Guidance for Implementing the UMTRA Project Long-term Surveillance Program (DOE, 1992a).

\section{$1.1 \quad$ BACKGROUND}

Title 1 of the Uranium Mill Tailings Radiation Control Act (UMTRCA) of 1978 (42 USC $\$ 7901$ et seq.) authorized the DOE to perform remedial action at 24 inactive uranium processing sites to reduce potential adverse health effects to the public from unstabilized RRM in and around the uranium mill tailings. The Durango, Colorado, uranium processing site in La Plata County, Colorado, was one of these 24 sites. The DOE, NRC, and the state of Colorado entered into a cooperative agreement under the UMTRCA, establishing the terms and conditions of the remedial action (DOE Cooperative Agreement No. DE-FCO481AL16257, 19 October 1981) (DOE, 1981). Concurrence from the NRC on the remedial action plan was received 4 November 1994 (Attachment 1).

\subsection{LICENSING PROCESS}

The NRC has developed regulations in 10 CFR $\$ 40.27$ for issuing a general license for the long-term care of UMTRA Project (Title 1) disposal sites, including the Bodo Canyon disposal site. The license is available only to the DOE (or any successor federal agency designated by the President of the United States) and has no termination date. The purpose of this general license is to ensure that the UMTRA Project disposal sites will be cared for in a manner that protects the public health and safety and the environment after the NRC and DOE concur that the remedial action is complete (i.e., acceptance of the Bodo Canyon Completion Report and Certification Summary) at that site and formally accepts the site-specific LTSP that meets the requirements of 10 CFR $\$ 40.27$. The Bodo Canyon Completion Report documents the disposal site as-built conditions. The DOE prepares a Certification Summary certifying satisfaction of approved RAP provisions and compliance with EPA standards.

When the general license becomes effective after approval of the LTSP, responsibility for the long-term surveillance program will be transferred to the DOE Grand Junction Projects Office (GJPO), Grand Junction, Colorado. The programmatic transfer will occur within 30 days of NRC notification that the 
license is in effect. The DOE remains the responsible federal agency unless a successor agency is designated by the President of the United States.

\section{Acquisition}

The land on which the disposal site is located was acquired by the Colorado Department of Public Health and Environment (CDPHE). The site consists of two parcels, Tracts 101 and 102. The parcels were deeded to CDPHE on 4 August 1987, and 6 November 1992, respectively. On 20 October 1993, the state of Colorado forwarded draft deeds and supporting documentation for the transfer of the site to the federal government, pursuant to 42 USC $\$ 7914$ (f). The U.S. Army Corps of Engineers, Omaha Office, must provide real estate support services to the DOE and is responsible for effecting the title transfer.

For additional information, see Attachment 2, which provides the legal description for the disposal site, Tracts 101 and 102.

\subsection{LONG-TERM SURVEILLANCE PLAN}

This document describes the long-term surveillance activities that will be conducted at the Bodo Canyon disposal site to ensure that it continues to perform as designed. This plan is based on the DOE's Guidance for Implementing the UMTRA Project Long-term Surveillance Program (DOE, 1992a).

This LTSP meets the requirements of 10 CFR $\S 40.27$ by addressing the following:

- Site description and ownership.

- Description of final site conditions.

- Site inspection procedures and personnel.

- Custodial maintenance and corrective action programs.

- Record keeping and reporting.

- Quality assurance (OA).

- Emergency response. 


\subsection{SITE FINAL CONDITIONS}

\subsection{PROCESSING AND DISPOSAL SITE HISTORY}

The Durango uranium processing mill was located southwest of the Durango town limits, on the west bank of the Animas River (Figure 2.1), located near the south end of a mill/tailings site operated from 1880 to 1930 . In 1942, U.S. Vanadium Corporation leased the property and constructed a uranium processing mill on the site. This mill operated until 1946, when the mill was shut down. In 1949, Vanadium Corporation of America (VCA) leased and subsequently purchased the processing site. The VCA operated the mill and sold uranium to the U.S. Atomic Energy Commission until March 1963, when the mill shut down permanently. Ranchers Exploration and Development Corporation purchased the mill in 1977. Hecla Mining Company acquired Ranchers Exploration and Development Corporation in July 1984. The Durango mill produced an estimated 1.2 million cubic yards $\left(\mathrm{yd}^{3}\right)\left(92,000\right.$ million cubic meters $\left.\left[\mathrm{m}^{3}\right]\right)$ of tailings. Other surface contamination included vicinity property material, contaminated earth, mill debris, slag, and windblown material. In March 1987. the DOE initiated remedial action to relocate the approximately $2.5{\text { million } \mathrm{yd}^{3}}^{3}$ $\left(1,900,000 \mathrm{~m}^{3}\right)$ of tailings piles and contaminated soils from the processing site to the Bodo Canyon disposal site. Relocation was completed in the fall of 1990 .

Prior to receiving tailings and contaminated soils from the processing site, the Bodo Canyon disposal site was used as pastureland and was managed by the U.S. Department of the Interior, Bureau of Land Management. No mining. milling, or other industrial activities occurred in the valley before the disposal cell was established.

\subsection{DESCRIPTION AND LOCATION OF THE DISPOSAL SITE AREA}

The disposal site comprises approximately 120.6 acres (ac) (48.8 hectares [ha]) in La Plata County, Colorado, approximately 3.5 road miles (mi) (5.6 kilometers [km]) southwest of Durango, Colorado (Figure 2.1), in the eastern half of Section 36, Township 35 North, Range 10 West, and the western half of Section 31, Township $341 / 2$ North, Range 9 West, New Mexico Principal Meridian (Figure 2.2) (DOE, 1993b).

The disposal site is in the upper west end of Bodo Canyon, an ephemeral drainage basin of about 4.5 square miles $\left(\mathrm{mi}^{2}\right)$ (11.6 square kilometers $\left[\mathrm{km}^{2}\right]$ ) bordered by Smelter Mountain on the north, Carbon Mountain on the south, and the Animas River on the east (Figure 2.2).

The disposal site lies at an elevation of approximately 7100 feet $(\mathrm{ft})(2200$ meters [m] ) above mean sea level (MSL). Area elevations range from $7725 \mathrm{ft}$ $(2355 \mathrm{~m}$ ) at the top of Smelter Mountain (approximately $0.85 \mathrm{mi}[1.4 \mathrm{~km}]$ from the site) to about $6600 \mathrm{ft}(2000 \mathrm{~m})$ at the mouth of Bodo Canyon. The Cliff House Sandstone of the Mesaverde Group (Cretaceous) underlies the site; 


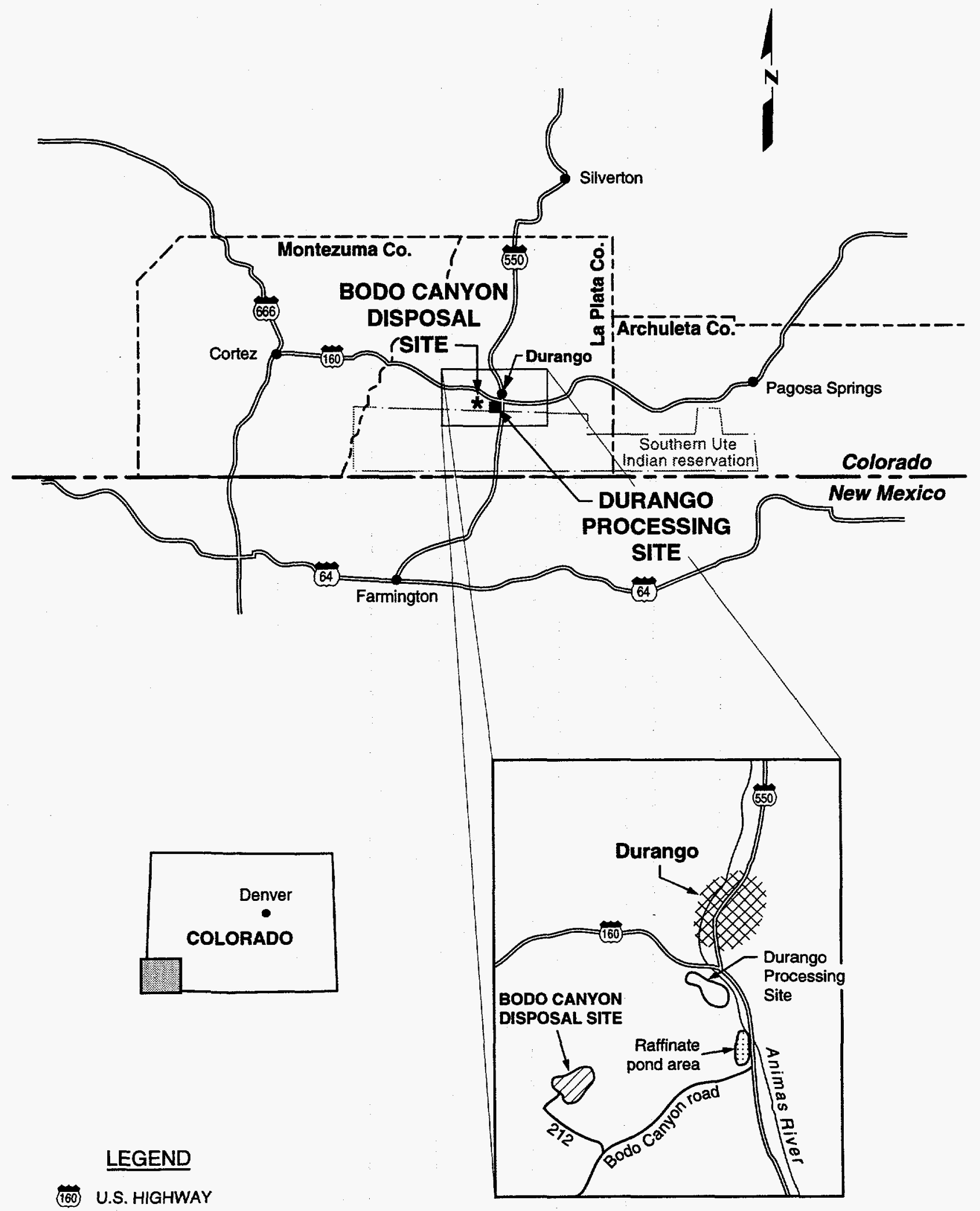

NOT TO SCALE

FIGURE 2.1

LOCATION OF BODO CANYON DISPOSAL SITE

LA PLATA COUNTY, COLORADO 


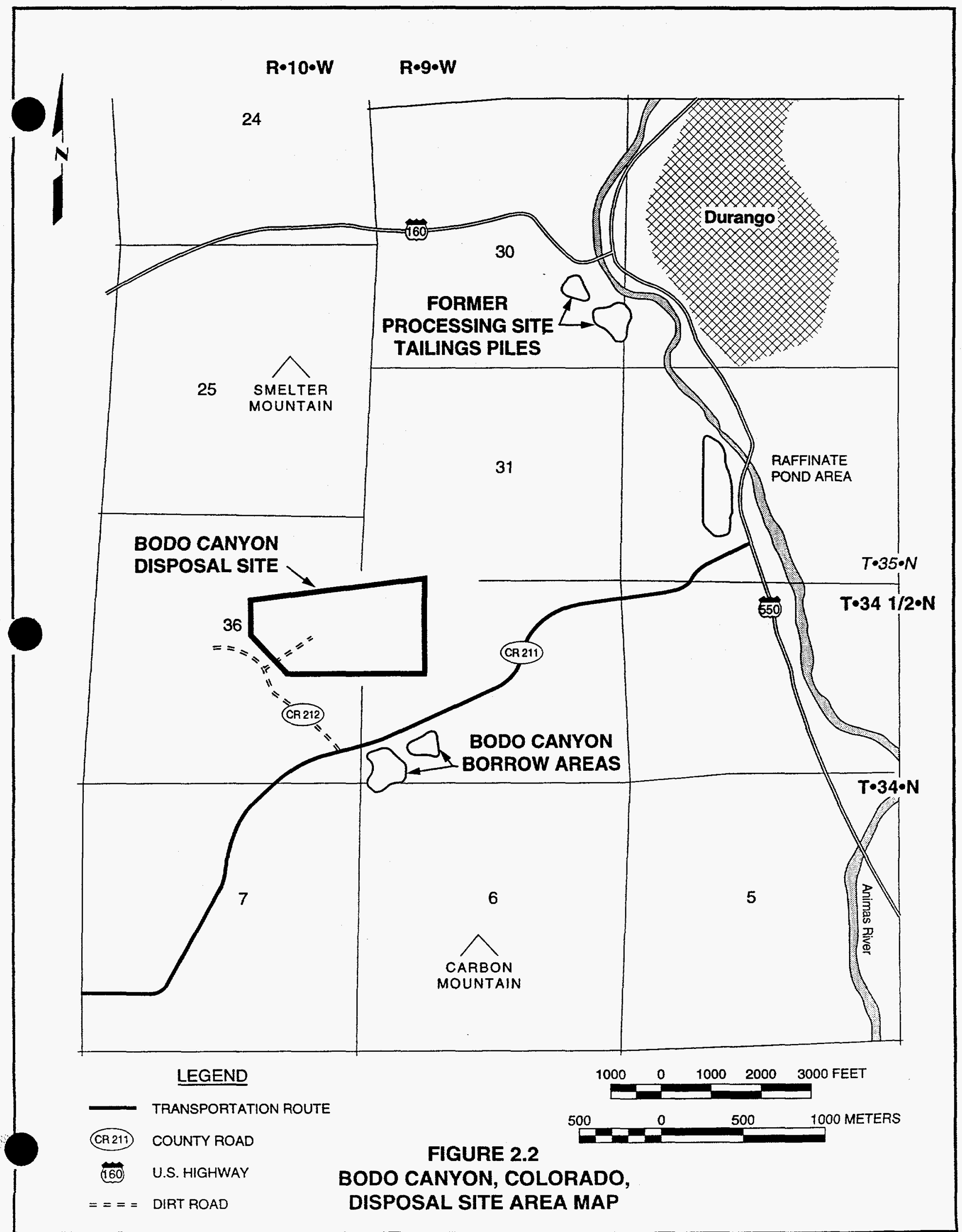


sandstone units are exposed in the hillside at the east end of the site. The site is near the north edge of the San Juan Basin. Rock formations in the area dip south toward the center of the basin. Grasses and sagebrush vegetate the bottomlands of Bodo Canyon (DOE, 1993b).

Figure 2.2 is a map of the Durango, Colorado, area. The disposal site can be located using the following directions:

1. Where U.S. Highway 160 joins U.S. Highway 550 (US-550/160) just west of downtown Durango, proceed south on US-550/160.

2. Drive south on US-550/160, turn west (right) on County Road 211 (CR 211); CR 211 becomes a dirt road.

3. Remain on CR 211, heading southwest.

4. A substation is on the right side of the road. Remain on CR 211.

5. Turn northwest (right) onto CR 212. Proceed northwest.

6. Turn north (right) onto the entrance road.

7. The site entrance gate is at the southwest corner of the site.

\subsection{DISPOSAL SITE ACCESS}

The supervisory general engineer at the GJPO holds keys to the lock on the disposal site security gate. The other key holders are the DOE Contractor representatives as assigned by DOE and CDPHE (Table 2.1).

\subsection{DISPOSAL CELL DESIGN}

The disposal cell is constructed partially below existing grade. It covers approximately 60 ac ( $24 \mathrm{ha}$ ), with maximum areal dimensions of $2400 \times$ $1300 \mathrm{ft}(730 \times 400 \mathrm{~m})$. Figure 2.3 is a plan view of the disposal cell.

The radon barrier thickness was determined to be conservative, based upon radiological characterization of the contaminated materials obtained prior to and during construction. The radon emanation rate from the completed disposal cell meets the EPA standard of 20 picocuries per square meter per second. The tailings were encapsulated with a compacted 2-ft $(0.6-\mathrm{m})$-thick radon barrier layer of uncontaminated silty clay and clay materials. On the sideslope, the upper 18 inches (46 centimeters $[\mathrm{cm}]$ ) of the radon barrier were amended with 7 percent bentonite to maintain a consistent radon barrier thickness on the top and sides of the cell. Additionally, the radon barrier on the topslope was constructed with a bentonite geomembrane (bentonite sandwiched between two geotextiles) on the surface to restrict infiltration into the barrier. The radon 
Table 2.1 Bodo Canyon, Colorado, disposal site access key holders

\begin{tabular}{|c|c|c|}
\hline Title and current contract & Telephone & Address \\
\hline GJPO supervisory general engineer & $(970)$ 248-6006 & $\begin{array}{l}\text { Grand Junction Projects Office } \\
2597 \text { B 3/4 Road } \\
\text { Grand Junction, Colorado } 81503\end{array}$ \\
\hline $\begin{array}{l}\text { Technical Assistance Contractor } \\
\text { UMTRA Project Manager } \\
\text { (as of date of publication) }\end{array}$ & $(505) 888-1300$ & $\begin{array}{l}\text { Jacobs Engineering Group Inc. } \\
2155 \text { Louisiana NE } \\
\text { Suite } 10,000 \\
\text { Albuquerque, New Mexico } 87110\end{array}$ \\
\hline $\begin{array}{l}\text { Colorado Department of Public Health } \\
\text { and Environment }\end{array}$ & $(970) 248-7165$ & $\begin{array}{l}\text { Colorado Department of Public } \\
\text { Health and Environment } \\
22256 \text { th Street } \\
\text { Room } 232 \\
\text { Grand Junction, CO } 81501\end{array}$ \\
\hline
\end{tabular}

barrier is further protected by a 6 -inch (150-millimeter [mm]) sand filter/drainage layer on the sideslopes and top.

The topslope was completed with a $1.5-\mathrm{ft}(0.5-\mathrm{m})$ biointrusion layer, a $2.5-\mathrm{ft}$ $(0.8-\mathrm{m})$ frost-protection layer, and a $6-$ inch $(150-\mathrm{mm})$ rock/soil matrix. The matrix has a 1.5 to 2.0 percent grade away from a drainage divide at the center of the cell. In addition to the rock/soil layer, the cell topslope is covered with native grasses. The cover system for the embankment topslope is illustrated in Figures 2.4 and 2.5 .

The sideslope was completed with a 6 -inch $(150-\mathrm{mm})$ bedding layer, a $1.5-\mathrm{ft}$ $(0.5-\mathrm{m})$ frost-protection layer, another 6 -inch $(150-\mathrm{mm})$ bedding layer, and a $1.0-\mathrm{ft}(0.3-\mathrm{m})$ riprap layer. The riprap is keyed along the cell perimeter to prevent headcutting erosion at the cell boundary.

The drainage features of the embankment and general site grading ensure long-term embankment stability as required in 40 CFR \$192.02(b). Runoff from the embankment flows to the apron and then to the adjacent natural ground on the northern slope of the cell. All other sideslopes of the cell drain to perimeter catchment ditches that channel the concentrated flows to outfall structures. Ditch No. 1 carries flow from the eastern slope and drains to an outfall structure at the arroyo north of the cell. Ditch No. 2 carries flows from the southern face of the cell and drains to an outfall structure at the escarpment to the east. Ditch No. 3 captures a smaller drainage from the northwestern and western slopes of the cell and a small upland drainage area. It also divides the drainage to the north and southwest. The ditches have sufficient depth and rock protection to carry runoff from the probable maximum precipitation (PMP) event. Significant precipitation events can create velocities capable of moving sediment buildup in the ditches. Flows in the major arroyos north and south of the cell, produced from a PMP event occurring in the upland drainage area, will not impact the toe of the disposal cell. 


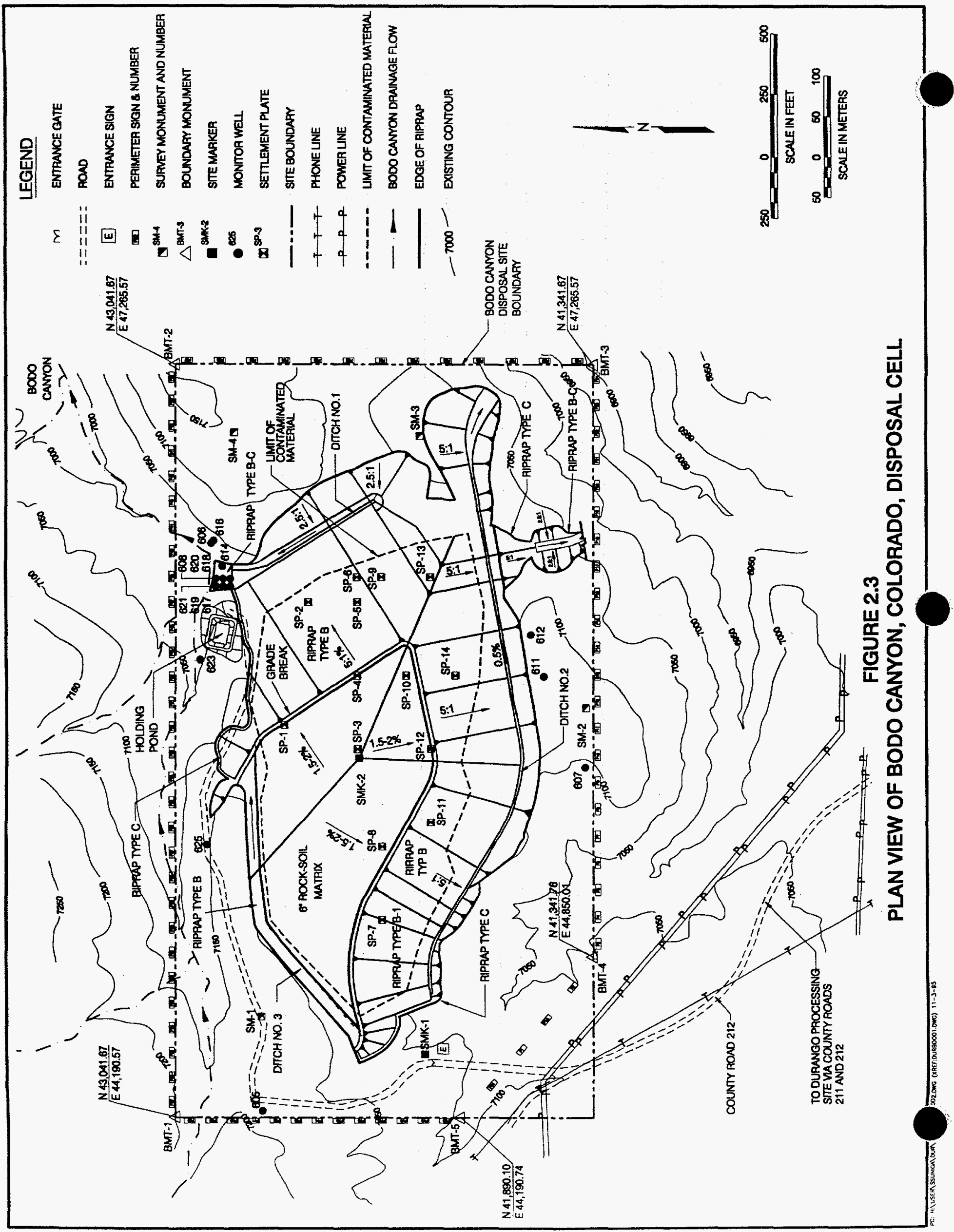



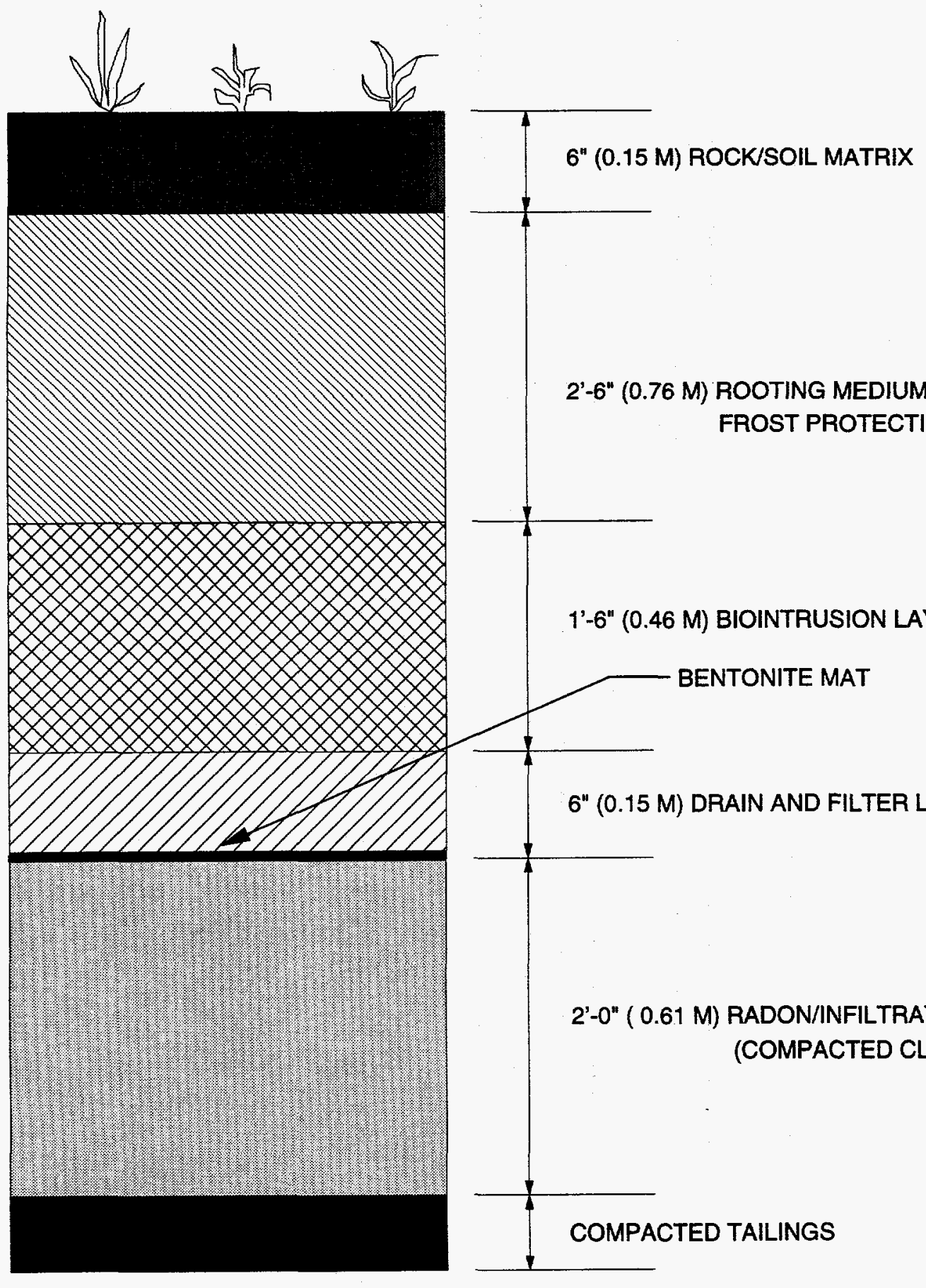

2'-6" (0.76 M) ROOTING MEDIUM/ FROST PROTECTION

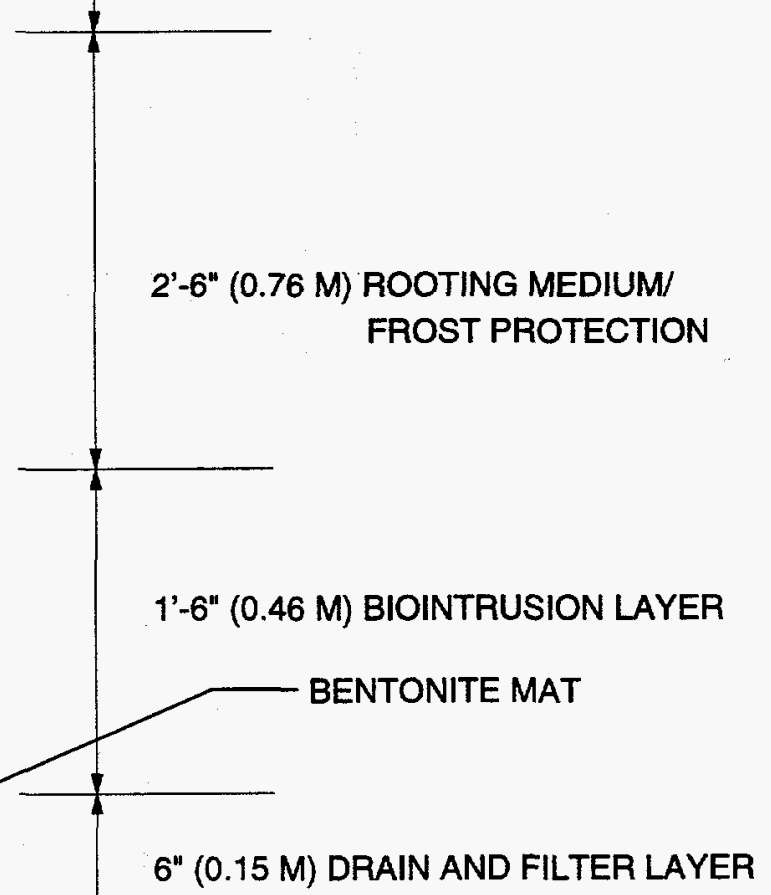

NOT TO SCALE

FIGURE 2.5

TOPSLOPE COVER SYSTEM BODO CANYON, COLORADO, DISPOSAL SITE 
The following major design features will mitigate potential ground water contamination at the disposal site:

- A low-permeability liner on the sides and below the contaminated tailings (Figure 2.4).

- A compacted radon/infiltration clay barrier above the tailings material (Figure 2.5).

- A high-conductivity sand drain/filter layer placed on the top of the radon barrier (Figure 2.5).

The low-permeability liner placed underneath the tailings material is composed of natural, recompacted, silty clay and clay soils. These soils have high neutralization, adsorption, and ion exchange potential and thus provide a high attenuating capacity to restrict downward contaminant migration through the barrier.

During disposal cell construction, a seepage required the construction of a toe drain and holding pond that will be in service for a relatively short period of time. The seepage water collected in the pond is treated periodically and discharged in accordance with the CDPHE discharge permit. Attachment 3 describes the seepage that developed and the criteria and plan for final closure and decommissioning of the toe drain and holding pond. Because the toe drain and pond are temporary, no long-term surveillance of these features is described in Attachment 3 of this document. However, in accordance with the CDPHE permit, the toe drain and pond are inspected monthly. Attachment 4 contains a copy of the Bodo Canyon Toe Drain Pond Discharge Permit Management Plan. 
-

○

- 


\subsection{SITE DRAWNGS AND PHOTOGRAPHS}

At the completion of remedial action, disposal site as-built conditions were documented with as-built drawings and photographs (MK-F, 1991). This information illustrates baseline conditions for comparison to future disposal site conditions.

A disposal site topographic map was prepared and will become part of the Durango permanent site file. The site inspection map will be updated, as necessary, after each site inspection. The disposal site maps and all drawings and photographs will be archived by the UMTRA Project Document Control Center (UPDCC). The topographic map, disposal site map drawings, and photographs may be further modified by the GJPO, as necessary, and the GJPO will be responsible for maintaining and archiving maps, drawings, and photographs after the Durango permanent site file is transferred to the GJPO.

\subsection{DISPOSAL SITE MAP}

The Bodo Canyon disposal site map (Plate 1) identifies the following site features:

- Disposal site plus an area of 0 to $650 \mathrm{ft}(0$ to $200 \mathrm{~m})$ around the site boundary.

- Topographic features.

- Permanent site surveillance features.

- Entrance road and gate/barricade.

- Drainage gully and drainage channels.

- Disposal site boundary.

- Disposal cell.

- Ground water monitoring wells.

Updates to the map will include the year of revision and the revision number.

The Bodo Canyon disposal site map will serve as the base map for site inspections (Section 6.4). A new, separate inspection map will be prepared after each inspection. Each site inspection map will indicate the year and type of inspection.

The Bodo Canyon disposal site base map and site inspection maps will become part of the Durango permanent site file.

\subsection{DISPOSAL SITE AS-BUILT DRAWINGS}

A set of as-built drawings provided by Morrison-Knudsen Ferguson (MK-F) illustrates the final disposal cell construction and final disposal site conditions. These drawings were used to prepare the disposal site map. They may be used to document changes in physical site conditions or the disposal cell over time and to develop corrective action plans, if required. At licensing, the DOE will 
transfer one original set of as-built drawings to the GJPO. These drawings will be filed and maintained in the Durango permanent site file at the GJPO.

\subsection{SITE BASELINE PHOTOGRAPHS}

A photographic record of the final site conditions at the Bodo Canyon disposal site will be included and maintained in the Durango permanent site file. This record consists of a series of aerial and ground photographs that provide a baseline visual record of final site construction and final site conditions to complement the as-built drawings. The post-construction photographs provide an orientation tool for site inspections and a baseline record of surveillance features.

\subsection{SITE AERIAL PHOTOGRAPHS}

Aerial photographs for the disposal site were taken throughout remedial action activities from 1987 to 1989 and in 1990 and 1991 after surface remedial action was complete. These photographs provide a record of site conditions, enabling inspectors to monitor changes in site conditions (e.g., erosion patterns, vegetation changes, and land use) over time. The photographs are a useful orientation tool for disposal site inspections. The need for new aerial photographs will be evaluated at 5-year intervals, beginning the year the site license becomes effective. Table 3.1 summarizes the specifications for aerial photographs at the Bodo Canyon disposal site. More detailed guidance is provided in Attachment 3 of the Guidance for Implementing the UMTRA Project Long-Term Surveillance Program (DOE, 1992a).

\subsection{SITE INSPECTION PHOTOGRAPHS}

Photographs will be taken during site inspections to document conditions at the disposal cell and the disposal site; they will be maintained in the Durango permanent site file. These photographs will provide a continuous record to monitor changing conditions over time and to compare with baseline photographs.

Each photograph will be recorded individually on a site inspection photo log (Attachment 5). An appropriate description of the feature photographed, including the azimuth (if necessary), will be entered into the log. Copies of disposal site inspection photographs and the photo log will be included in annual site inspection reports.

When possible, each photograph will include a reference point such as a survey monument or boundary monument, site marker, or monitor well. For large-scale features such as drainage ditches or disposal cell slopes, a north arrow and scale will be included on the developed photographs for reference.

For specific areas in which a photograph is used to monitor change over time, the distance from the feature and the azimuth will be recorded, and all 
Table 3.1 Aerial photography specifications for the Bodo Canyon, Colorado, disposal site

Area to be photographed

Products to be delivered

Flight date

\section{Camera}

Film

Filter

Flight line coverage

Ground control
Final disposal site plus a minimum of $0.25 \mathrm{mi}(0.4 \mathrm{~km})$ beyond site boundaries unless site conditions require otherwise.

One set of vertical color, infrared stereo contact prints, 9 -in $(230-\mathrm{mm})$, scale 1 inch $=200 \mathrm{ft}(1 \mathrm{~mm}=2.4 \mathrm{~m})$ (representation fraction 1:2400); double weight, glossy, not trimmed.

One index map, scale 1 inch $=200 \mathrm{ft}(1 \mathrm{~mm}=2.4 \mathrm{~m})$; flight lines and frame numbers will be provided.

One set of 2 each of low- and high-oblique photographs (and negatives) in natural color, 8- $x$ 10-inch (200- x 250-mm); or 9- x 9-inch (230- x 230-mm) contact prints.

To be determined upon the acceptance of this LTSP.

Precision, 9- $x$ 9-inch (230- x 230-mm) format for vertical photos. A $35-\mathrm{mm}$ (single lens reflex) or larger format camera for oblique photos is acceptable.

Eastman-Kodak Aerochrome Infrared 2443, or its equivalent, for vertical photos.

Eastman-Kodak Ektacolor, or its equivalent, for oblique photos.

Wratten No. 12 or 15 for infrared photos. Skylight filter for color photos.

60 percent end overlap; 30 percent average side overlap.

Control stations will be second order, Class 1, for horizontal control and third order for vertical control (standard U.S. Geological Survey map accuracy specifications). 
subsequent photographs should be taken from the same orientation to provide an accurate picture of changing conditions. The magnetic declination of the compass should be corrected for true north. This information will also be provided on the site inspection checklist and photo log.

Features to be photographed

The following disposal site features should be documented with photographs during every scheduled inspection at the Bodo Canyon disposal site:

- Permanent site surveillance features (Plate 1).

- Entrance road and gate/barricade.

- Drainage gully and drainage channels.

- Disposal cell.

- Ground water monitor wells.

- Holding pond.

- Erosion protection material (riprap).

- Vegetation.

- New or potential problem areas. 


\subsection{PERMANENT SITE SURVEILLANCE FEATURES}

Survey monuments (SM), boundary monuments (BMT), site markers (SMK), and entrance and perimeter signs are the permanent surveillance features at the disposal site. Four survey monument coordinate locations are listed in Table 4.1. Five boundary monuments define the corners of the unfenced perimeter of the disposal site. Eighty-two warning signs are placed around the perimeter of the disposal site.

The construction and emplacement of the site surveillance features, described below, meet the specifications delineated in the DOE's Guidance for Implementing the UMTRA Project Long-Term Surveillance Program (DOE, 1992a).

\subsection{SURVEY MONUMENTS}

SM-1 is in the northwest quadrant of the site, SM-2 is south of the disposal cell, and SM-3 and SM-4 are to the east (Plate 1). The monuments, Bernsten RT-1 metal markers, were set into the top of a truncated cone of reinforced concrete set in concrete. The design of the survey monuments is shown in Figure 4.1.

\subsection{BOUNDARY MONUMENTS}

Five Bernsten Federal aluminum survey monuments, Model A-1, were used for the site boundary monuments (BMT-1, BMT-2, BMT-3, BMT-4, and BMT-5). BMT-1, BMT-2, and BMT-3 mark the site's northwest, northeast, and southeast corners (Plate 1). BMT-4 is at the west end of the south boundary, and BMT-5 is at the south end of the west boundary (MK-F, 1991). The design of the boundary monument is shown in Figure 4.2.

\subsection{SITE MARKERS}

Two unpolished granite site markers (SMK-1 and SMK-2) are within the restricted site boundary. SMK-1 is just inside the entrance gate. SMK-2 is on top of the disposal cell revegetated area. Site markers were constructed with the dimensions shown in Figures 4.3 and 4.4. The markers identify the disposal site, the general location of the disposal cell, the date of closure ( 3 August 1990), the dry tonnage of RRM $(3,460,000$ dry tons [3,140,000 tonnes]), and the curies of radioactivity (1400 curies, radium-226) (Figure 4.5).

\subsection{ENTRANCE AND PERIMETER SIGNS}

The site entrance sign is at the entrance gate (Figure 4.6). In addition to the entrance sign, 82 perimeter signs are located at the site (Figure 4.7). These signs display the international symbol indicating the presence of radioactive materials. They also state that the disposal site is U.S. Government property and forbid trespassing. The entrance sign has the same information as the perimeter signs, plus the name of the site and the name and telephone number 
Table 4.1 Locations of monuments and markers, Bodo Canyon, Colorado, disposal site

\begin{tabular}{|c|c|c|c|}
\hline Symbol & $\begin{array}{l}\text { Elevation } \\
12 / 06 / 93 \\
\end{array}$ & $\begin{array}{l}\text { Elevation } \\
10 / 20 / 93 \\
\end{array}$ & Coordinates" \\
\hline \multicolumn{4}{|c|}{ Settlement plates } \\
\hline S-1 & 7146.83 & 7146.72 & N 42600.4/E 45799.5 \\
\hline S-2 & 7072.57 & 7072.48 & N 42500.0/E 46300.0 \\
\hline S-3 & 7151.79 & 7151.58 & N 42299.5/E 45700.1 \\
\hline$S-4$ & 7144.58 & 7144.40 & N 42299.7/E 46000.2 \\
\hline S-5 & 7093.95 & 7093.90 & N 42299.8/E 46300.1 \\
\hline S-6 & 7076.93 & 7076.88 & N 42300.8/E 46400.2 \\
\hline S-7 & 7122.30 & 7122.18 & N 42200.4/E 45000.4 \\
\hline S-8 & 7147.30 & 7147.13 & N 42199.6/E 45299.7 \\
\hline S-9 & 7087.71 & 7087.66 & N 42200.6/E 46400.1 \\
\hline S-10 & 7146.98 & 7146.84 & N 42100.2/E 46000.1 \\
\hline$S-11$ & 7125.55 & 7125.46 & N 42000.5/E 45400.0 \\
\hline S-12 & 7144.15 & 7144.02 & N 41999.6/E 45700.2 \\
\hline S-13 & 7111.41 & 7111.29 & N 41964.2/E 46334.6 \\
\hline S-14 & 7112.53 & 7112.43 & N $41899.8 / E 46000.3$ \\
\hline \multicolumn{4}{|c|}{ Survey monuments } \\
\hline SM-1 & 7178.35 & & N 42692.34/E 44591.44 \\
\hline SM-2 & 7124.95 & & N 41370.10/E 45872.37 \\
\hline SM-3 & 7125.85 & & N 42035.81/E 46964.05 \\
\hline$S M-4$ & 7145.62 & & N 42804.37/E 46991.91 \\
\hline \multicolumn{4}{|c|}{ Boundary monuments } \\
\hline BMT-1 & & & N 43041.67/E 44,190.57 \\
\hline BMT-2 & & & N 43041.67/E 47,265.57 \\
\hline BMT-3 & & & N 41341.67/E 47,265.57 \\
\hline BMT-4 & & & N 41341.76/E 44,850.01 \\
\hline BMT-5 & & & N $41890.10 / E$ 44,190.74 \\
\hline
\end{tabular}

"Based on project survey control points established by the Bureau of Land Management. 


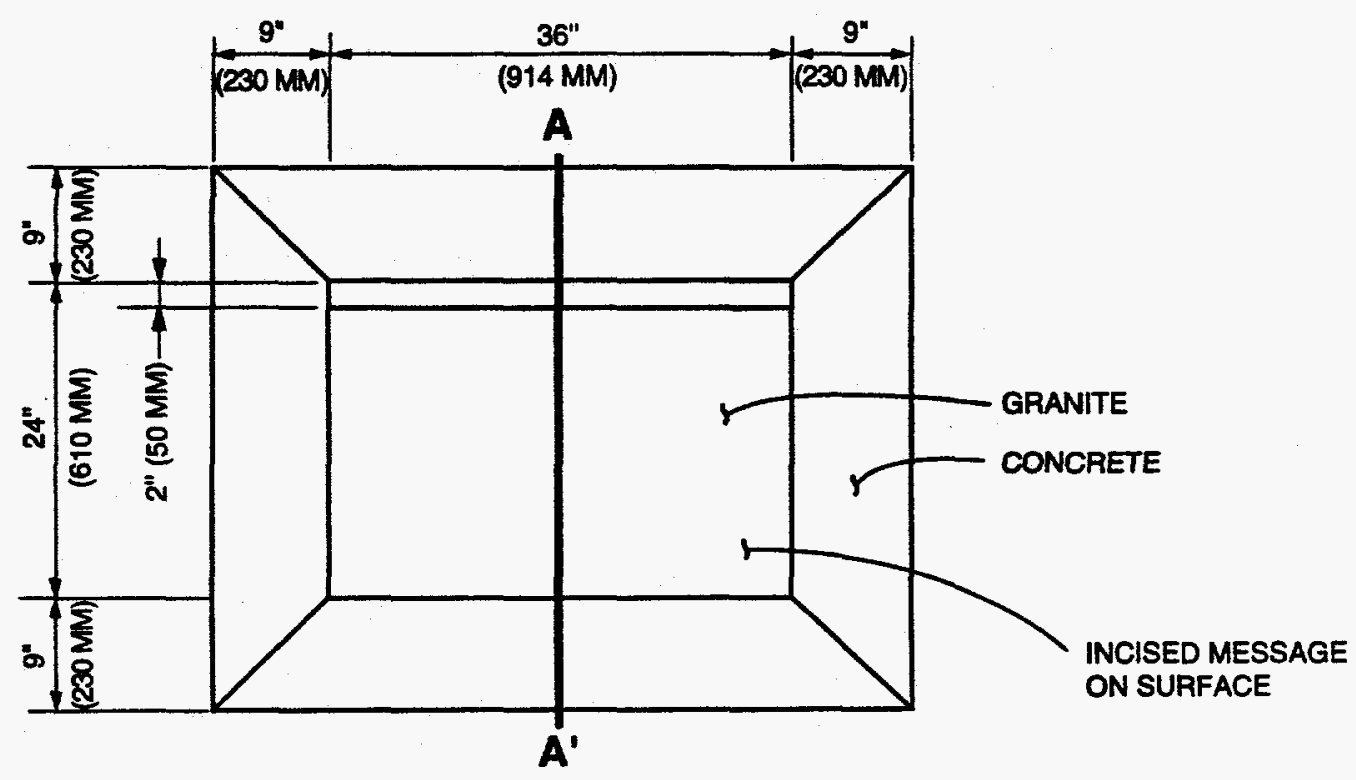

PLAN VIEW

SCHEMATIC - NOT SHOWN TO SCALE

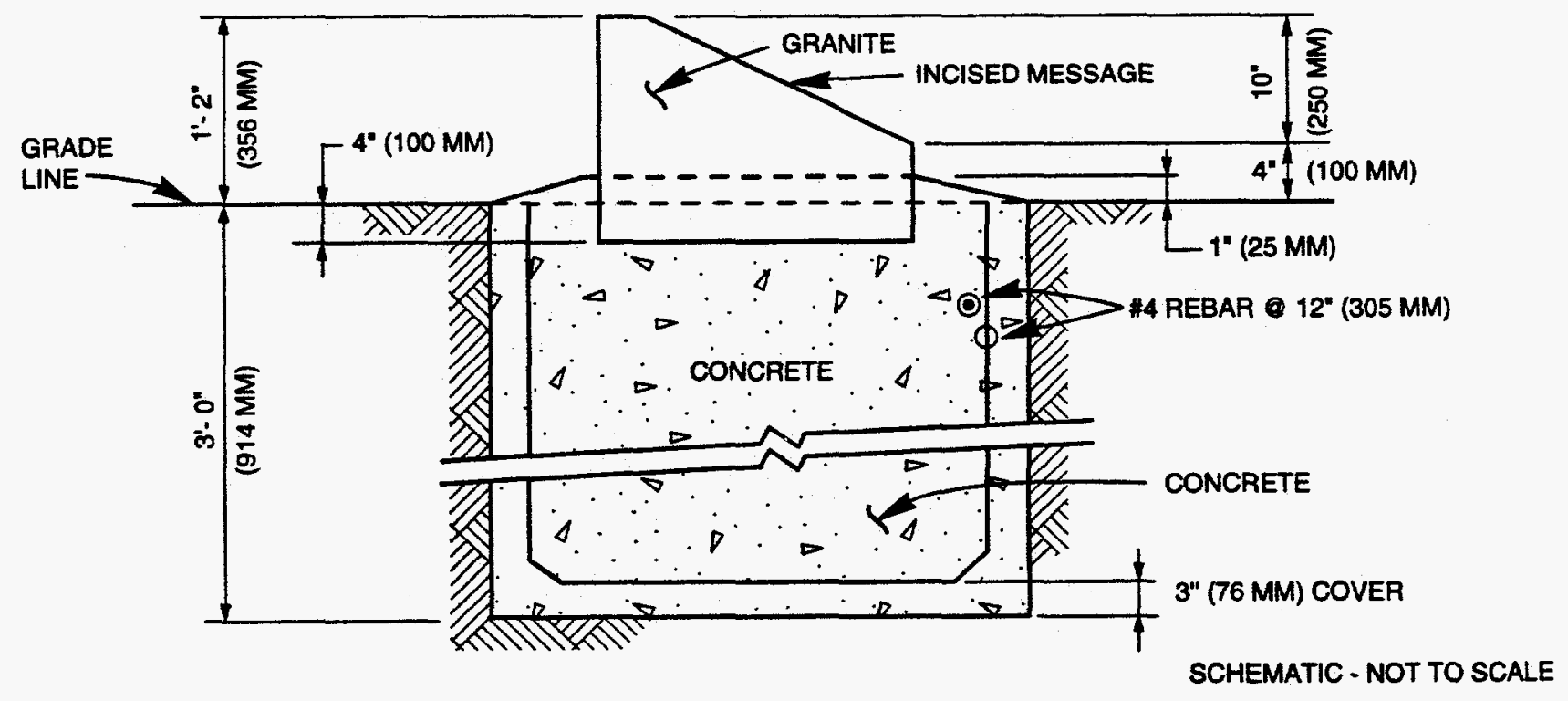

SECTION A - $A^{\prime}$

MODIFIED FROM MK-F, 1991

FIGURE 4.3

UMTRA PROJECT ENTRANCE SITE MARKER (SMK-1) BODO CANYON, COLORADO, DISPOSAL SITE 


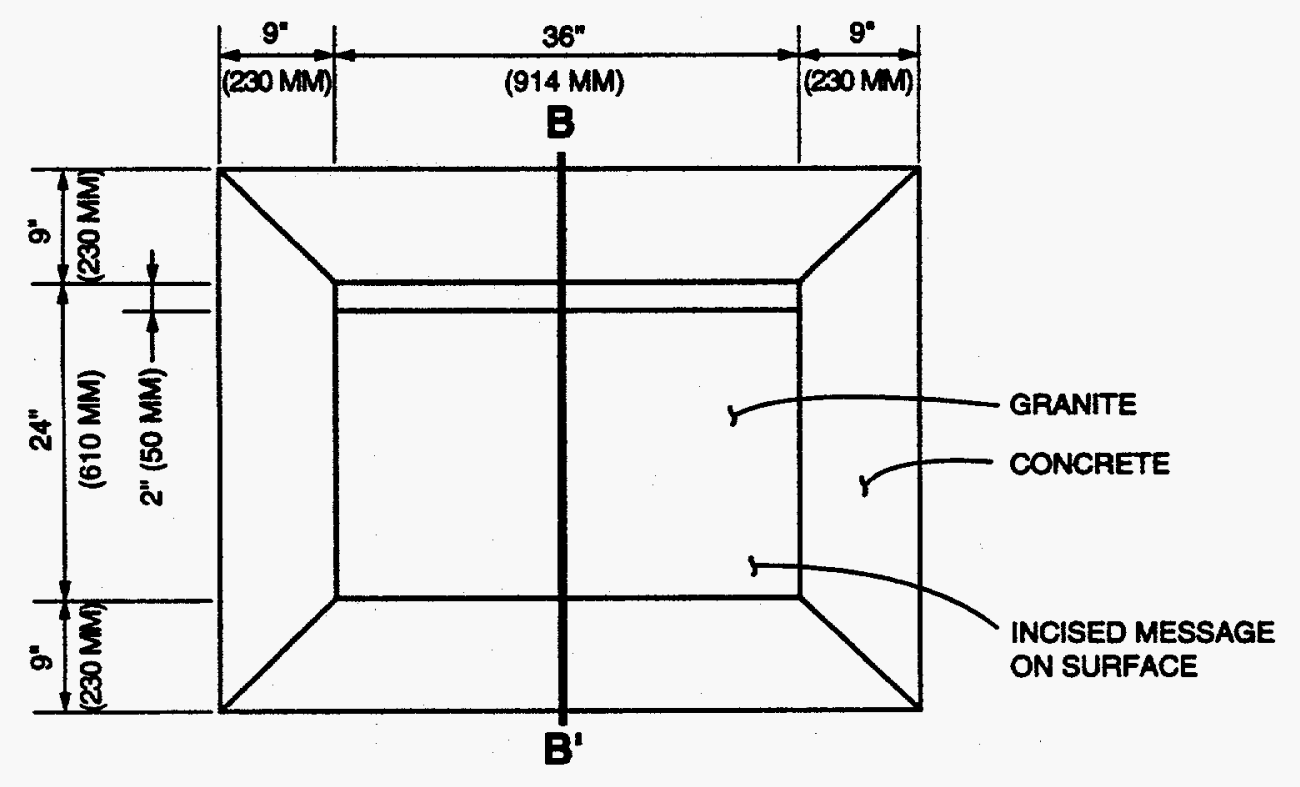

PLAN VIEW

SCHEMATIC - NOT SHOWN TO SCALE

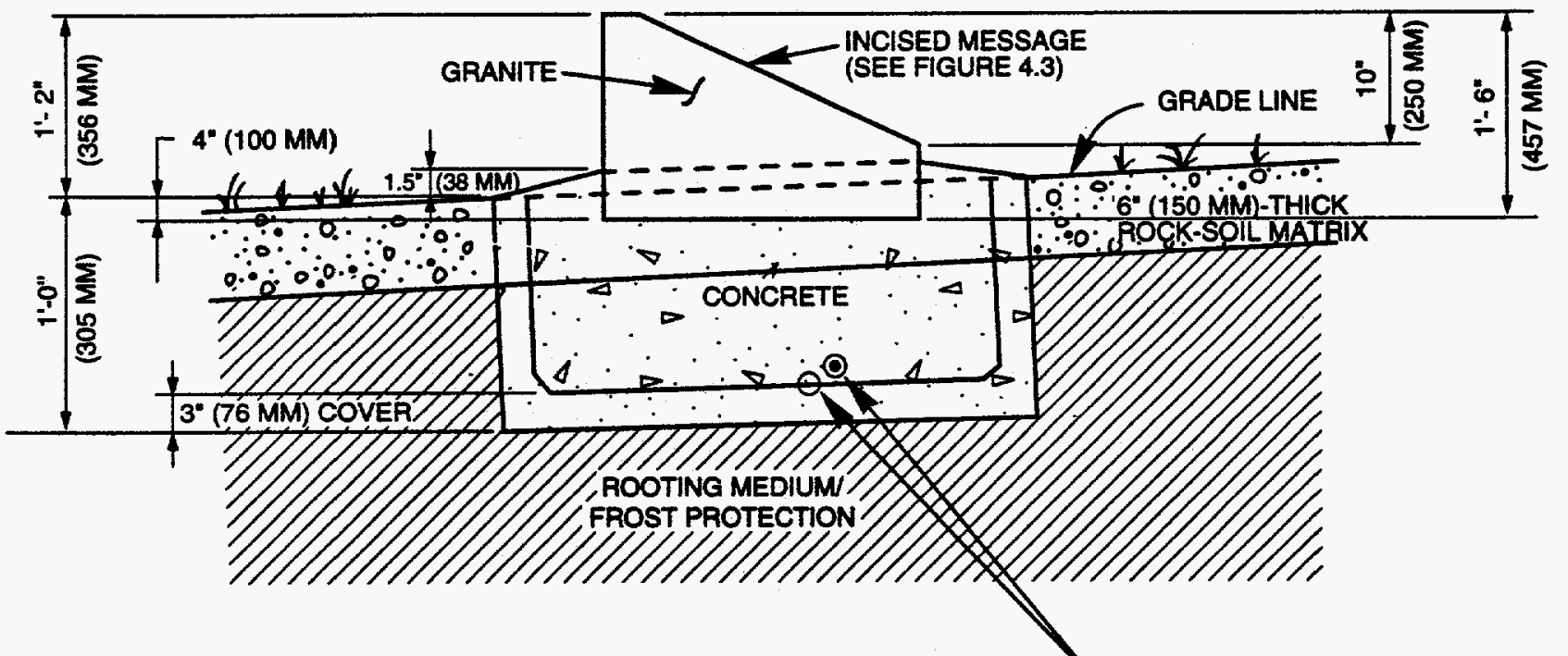

"4 REBAR — 12" (305 MM) EACH WAY

SCHEMATIC - NOT TO SCALE

SECTION B - B'

FIGURE 4.4

UMTRA PROJECT SITE MARKER AT CREST OF DISPOSAL CELL BODO CANYON, COLORADO, DISPOSAL SITE

MODIFIED FROM MK-F, 1991 


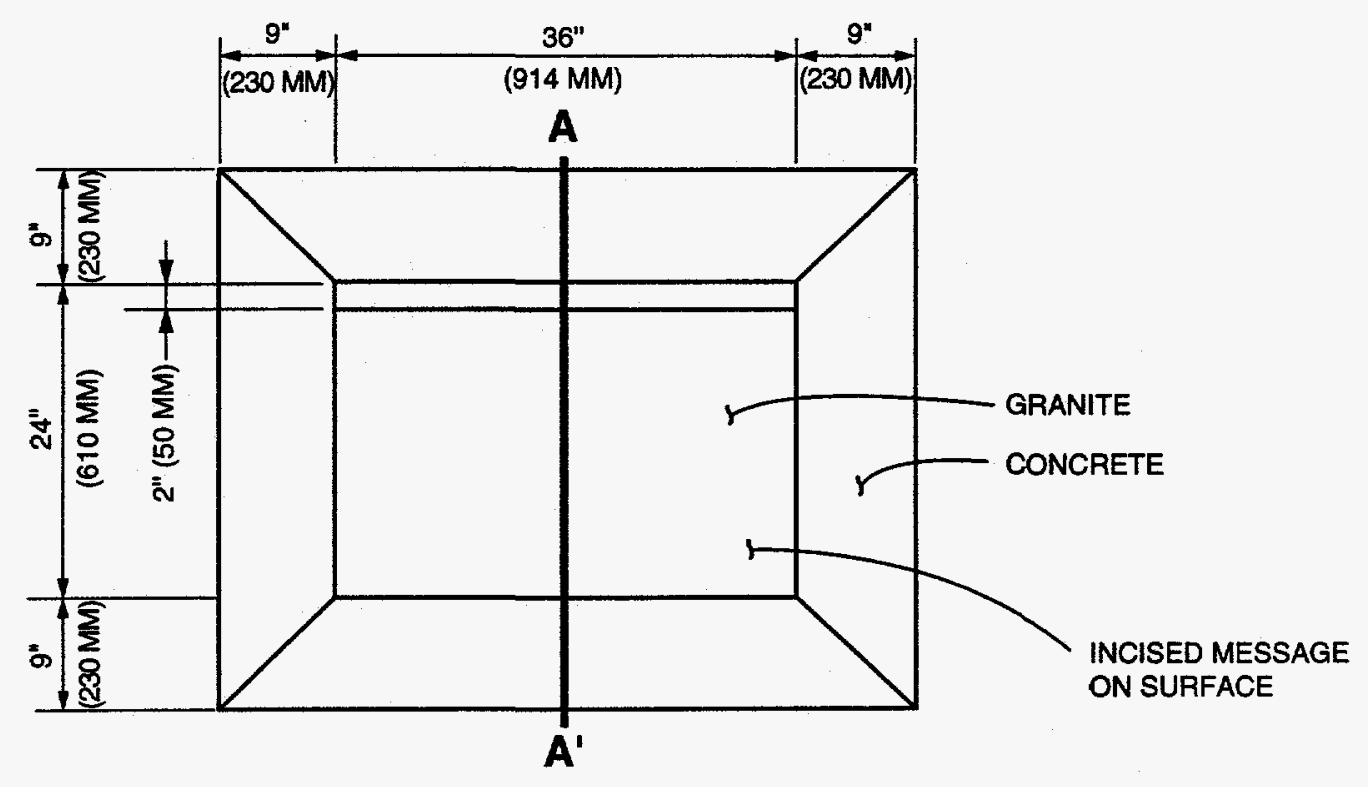

PLAN VIEW

SCHEMATIC - NOT SHOWN TO SCALE

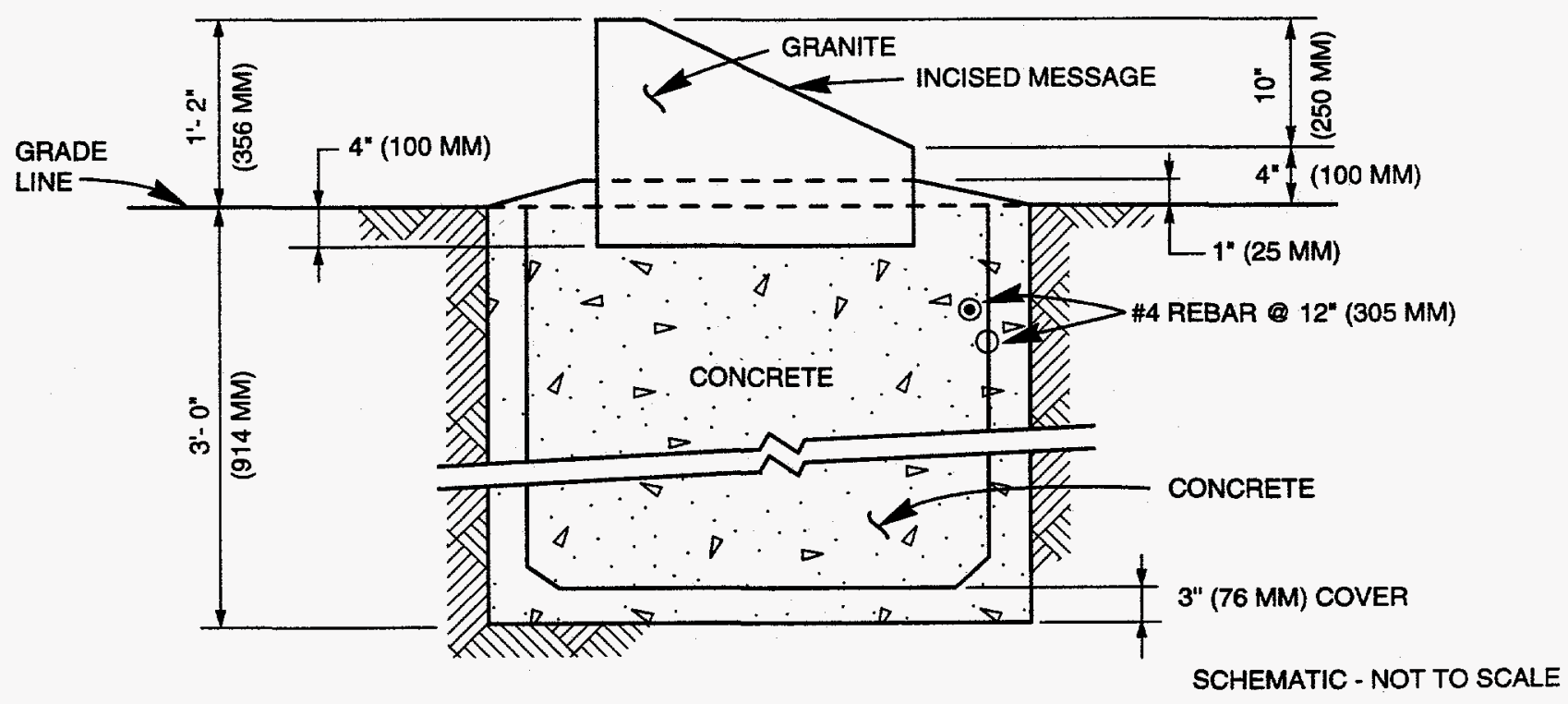

SECTION A - $A^{\prime}$

MODIFIED FROM MK-F, $1987 \mathrm{~b}$

FIGURE 4.3

UMTRA PROJECT ENTRANCE SITE MARKER (SMK-1) BODO CANYON, COLORADO, DISPOSAL SITE 


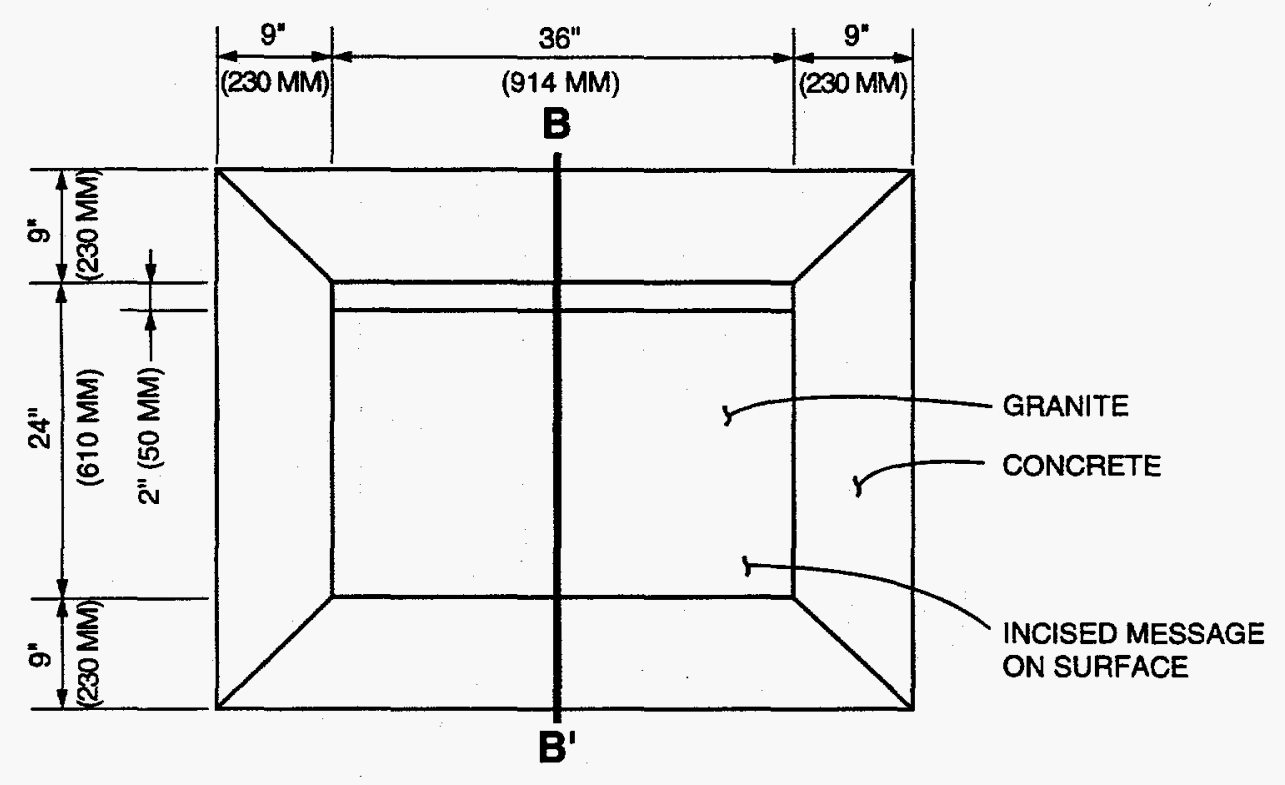

PLAN VIEW

SCHEMATIC - NOT SHOWN TO SCALE

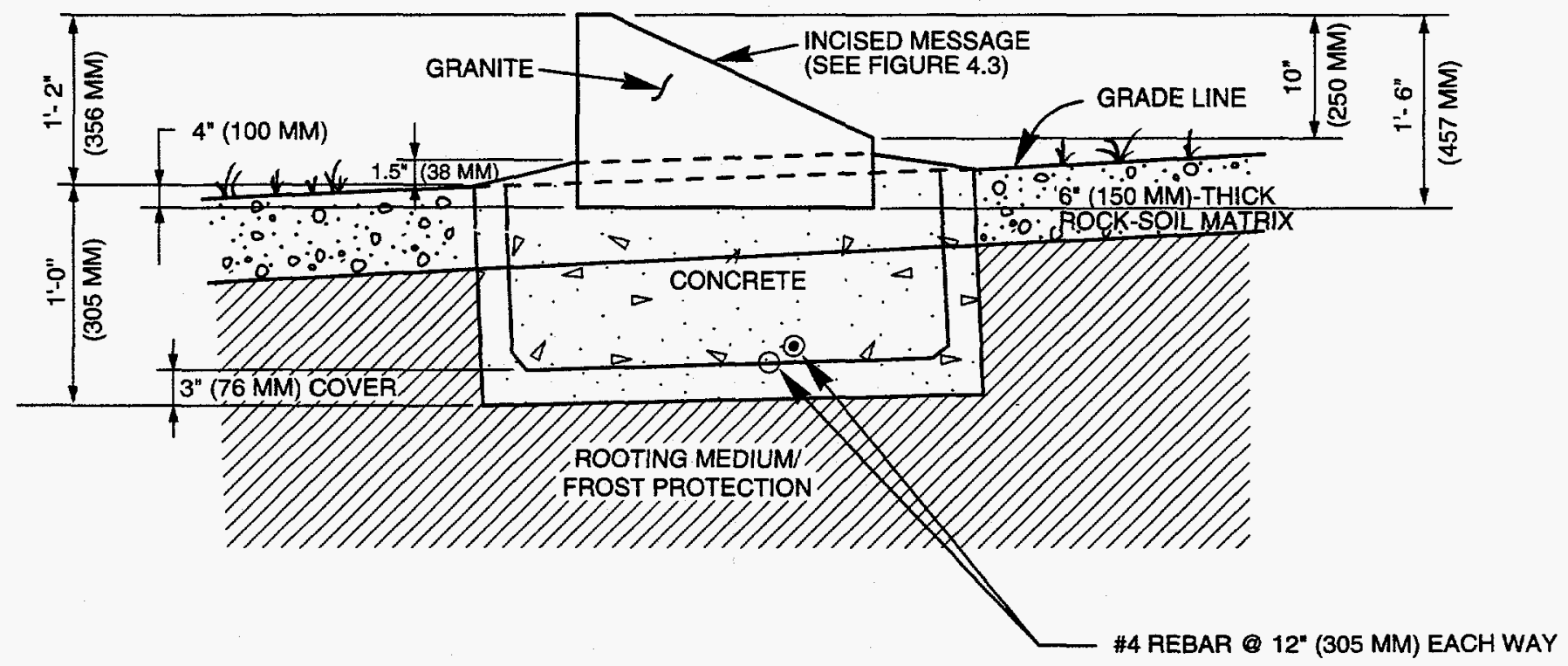

SCHEMATIC - NOT TO SCALE

SECTION B - B

FIGURE 4.4

UMTRA PROJECT SITE MARKER AT CREST OF DISPOSAL CELL BODO CANYON, COLORADO, DISPOSAL SITE 


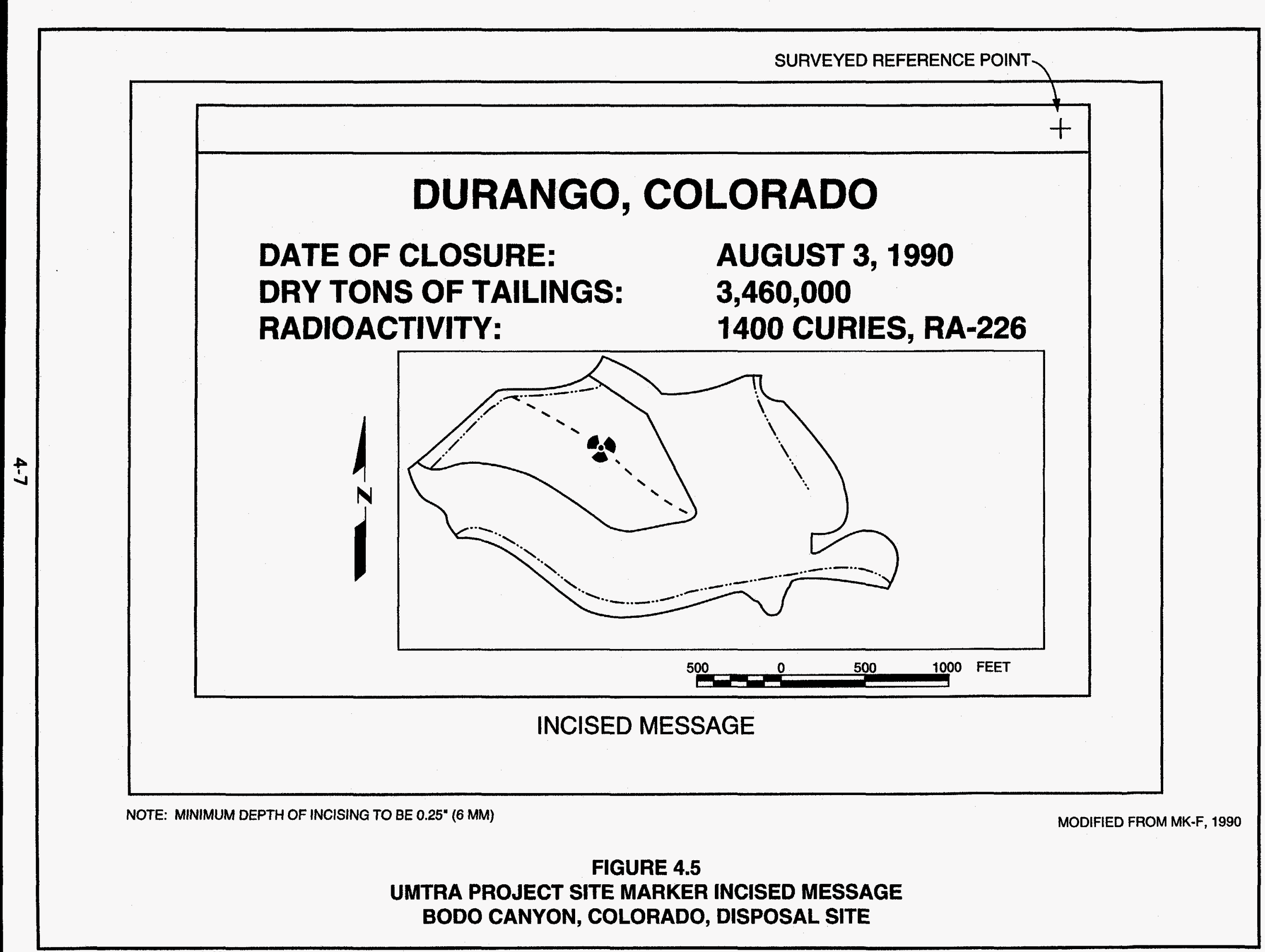




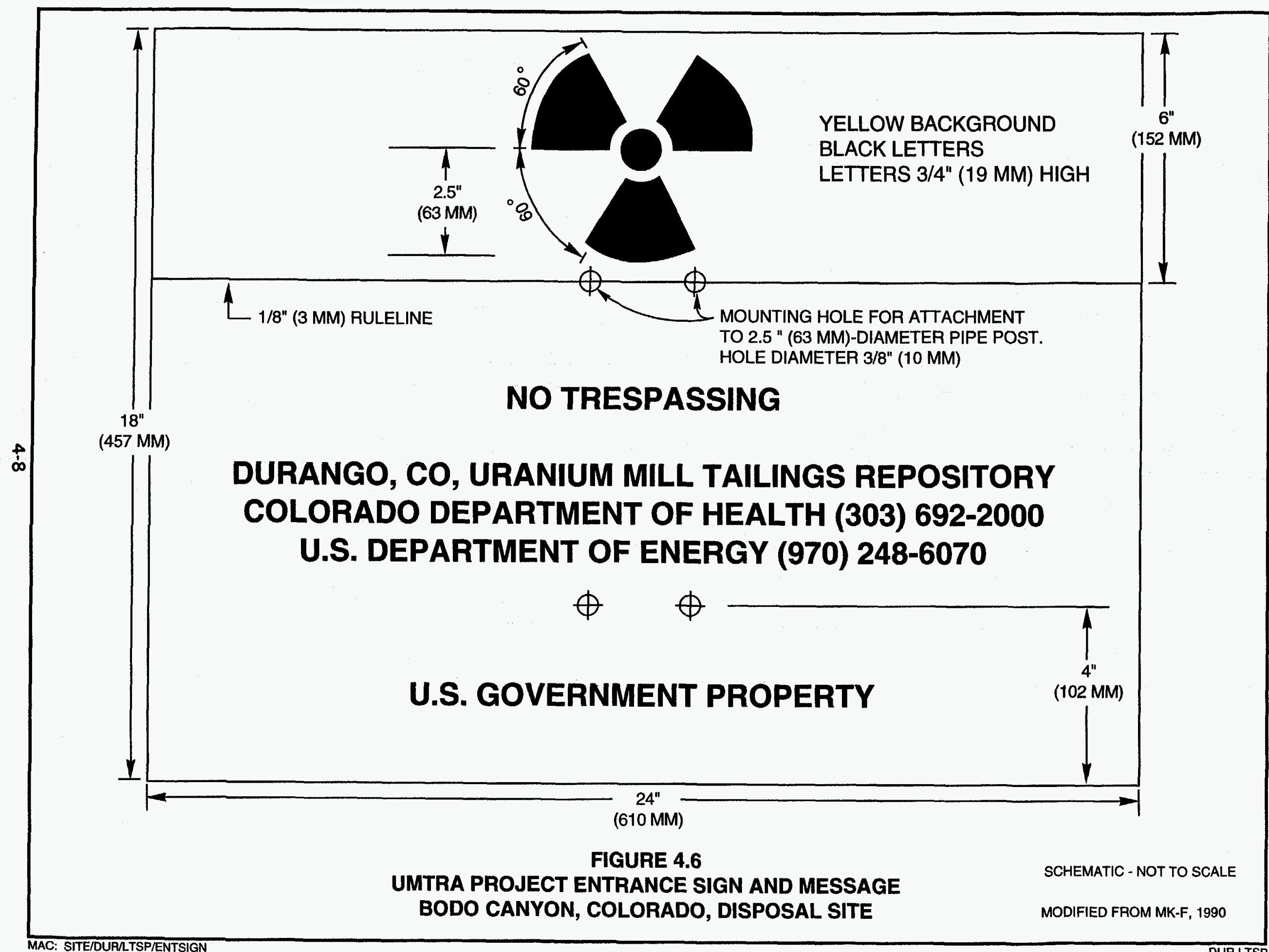




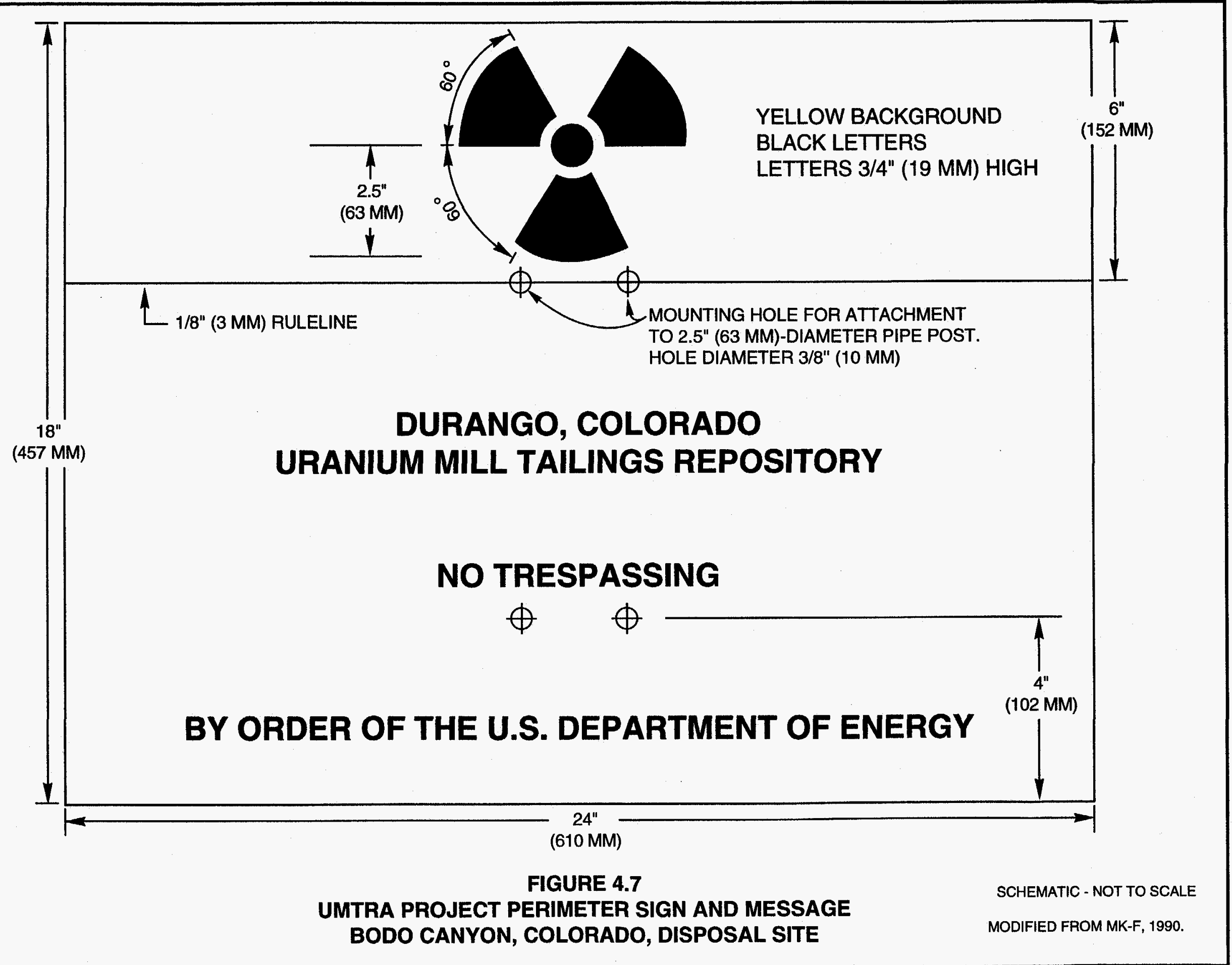


of the DOE GJPO and CDPHE. When the DOE and CDPHE telephone numbers change, the signs will be corrected.

The signs are constructed in accordance with the dimensions and specifications shown in Figures 4.6 and 4.7.

\subsection{SETTLEMENT PLATES}

Fourteen settlement plates are located on the disposal site, primarily on the south and east sideslopes of the disposal cell (Plate 1). The total long-term settlement of the disposal cell could be measured using the 14 settlement plates. The plates were installed after the disposal cell was completed, using the specifications in Figure 4.8. The coordinate locations are listed in Table 4.1.

\subsection{ADDITIONAL SITE-SURVEILLANCE FEATURES}

A lined rectangular holding pond at the northeast corner of the disposal cell serves as the collection and treatment point for construction water draining from the base and toe of the disposal cell. An 8-ft $(2.4-\mathrm{m})$ post-and-multiple-stand wire deer fence surrounds the pond; access is gained through an unlocked gate at the northeast corner of the fence. 


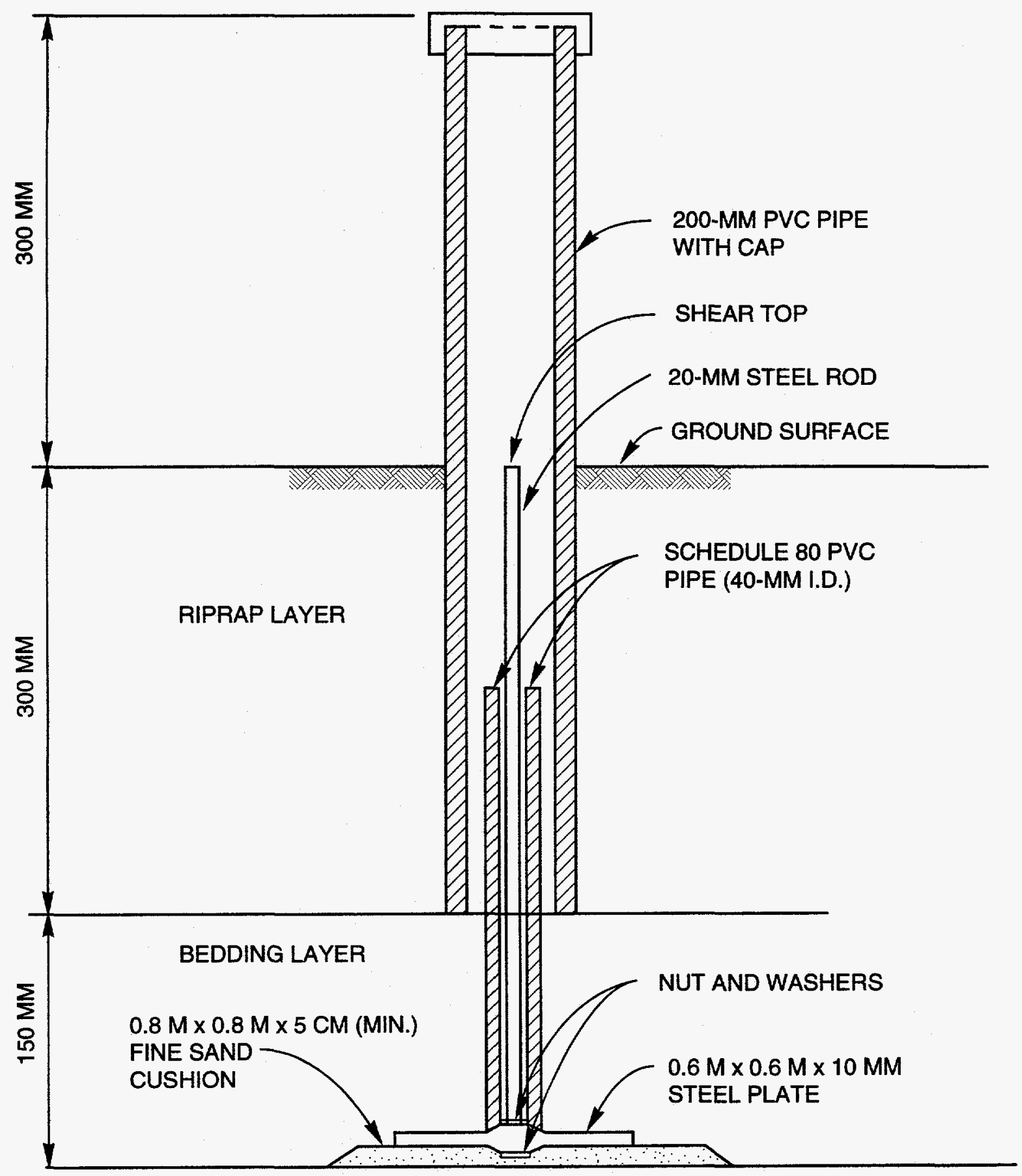

RADON BARRIER LAYER

SCHEMATIC - NOT TO SCALE

FIGURE 4.8

UMTRA PROJECT SETTLEMENT PLATE BODO CANYON, COLORADO, DISPOSAL SITE 



\subsection{GROUND WATER MONITORING}

Ground water monitoring at the Bodo Canyon disposal site is required under the regulations in 40 CFR $\$ 192.04$. The purpose of long-term monitoring is to verify that the performance of the disposal cell complies with the ground water design standards specified in the RAP (DOE, 1991). The ability of the disposal cell to protect ground water depends on its engineering features and on its physical location. The design of the disposal cell minimizes contaminant migration from the disposal cell into foundation materials. The location of the cell at the upper end of the valley prevents infiltration of surface runoff in to the cell. Therefore, drainage from the cell into the foundation material will meet ground water protection standards as a result of the following design considerations:

- The evapotranspiration of precipitation from the rock/soil and vegetative cover will reduce the amount of infiltrating water.

- The highly conductive sand filter/drainage layer on top of the radon barrier will drain much of the infiltrating water to the boundaries of the cell.

- The low permeability of the radon/infiltration barrier on top of the cell will prevent much of the infiltrating water from entering the cell.

- The low permeability and attenuating properties of the liner under the tailings material will reduce the rate of contaminant migration draining from the cell into subsoils beneath the cell.

As a result of these considerations, contaminated water that does filtrate into the subsoils beneath the cell will migrate as unsaturated flow and the contaminant transport will be attenuated through the residual moisture storage capacity of the alluvial material. Contaminant transport also will be attenuated by the natural geochemical adsorption capacity of subdisposal cell sediments. The RAP details these barriers to contaminant transport (DOE, 1991).

\subsection{GROUND WATER CHARACTERIZATION}

The DOE has characterized the hydrogeologic units and has identified the constituents of concern at the disposal site, which are further discussed below.

\subsubsection{Hydrostratigraphy}

\section{Physiographic setting}

The disposal cell is in a valley that trends southwest-to-northeast. Prior to installation of the disposal cell, the valley elevation ranged from approximately $7190 \mathrm{ft}(2190 \mathrm{~m})$ above MSL near the western end of the property to about $6900 \mathrm{ft}(2100 \mathrm{~m})$ above MSL at the extreme southeastern corner of the site. Figure 5.1 shows the topography of the surrounding area after the cell was 
completed. The canyon is bordered on both the northern and southern flanks by bedrock-supported ridges (Figure 5.2). The northern ridge is over $7160 \mathrm{ft}$ $(2180 \mathrm{~m})$ high, and the southern ridge is over $7100 \mathrm{ft}(2160 \mathrm{~m})$ high. Elevation at the top of the disposal cell is approximately $7145 \mathrm{ft}(2178 \mathrm{~m})$ above MSL. East-flowing arroyos are located north and south of the two flanking ridges. These arroyos are dry much of the year.

\section{Geology}

The bedrock underlying the disposal site and supporting the ridges north and south of the canyon is the Cliff House Sandstone (CGS, 1981). The bedrock dips southeast approximately 9.5 degrees.

The Cliff House Sandstone is approximately $200 \mathrm{ft}(60 \mathrm{~m})$ thick and contains two distinct units. The lower unit, which contains about $110 \mathrm{ft}(34 \mathrm{~m})$ of interbedded siltstone and sandstone with sandstone beds up to $3 \mathrm{ft}(1 \mathrm{~m})$ thick, supports the ridge north of the disposal cell and outcrops in the arroyo south of the south-flanking ridge. The upper unit of the Cliff House Sandstone is more shaley and contains fewer and thinner sandstone beds. This unit is approximately $90 \mathrm{ft}(30 \mathrm{~m})$ thick and supports the southern ridge.

The Cliff House Sandstone is underlain by the Menefee Formation, which is between 250 and $350 \mathrm{ft}(80$ and $110 \mathrm{~m})$ thick. The Menefee Formation outcrops in the arroyo at the extreme northeastern corner of the site. The contact between the lower unit of the Cliff House Sandstone and the Menefee Formation is distinguished primarily by evidence of coal and carbonized fragments in the Menefee. Otherwise, the gross lithologies of the two formations are very similar.

A paleochannel trending southwest-northeast in the lower unit of the Cliff House Formation parallels the axis of the valley occupied by the disposal cell (Figure 5.1). This paleochannel intersects the valley occupied by the eastflowing arroyo north of the disposal cell.

The paleochannel is filled with as much as $65 \mathrm{ft}(20 \mathrm{~m})$ of alluvium consisting of silty clay, silt, and sand with some sandstone and shale fragments. This alluvium thins and is absent along the sides of the ridges north and south of the disposal cell. During remedial action, the alluvium was shaped and compacted with additional imported silty clay and clay soil, forming a low-permeability base for the disposal cell, and restricting the downward migration of contaminants (Figures 5.2 and 5.3).

\section{Ground water (bedrock)}

Ground water elevations measured in monitor wells drilled into the bedrock beneath the cell before its construction, and into the bedrock north, south, and east of the cell, do not clearly identify a piezometric surface, flow direction, or gradient. Ground water relatively near the land surface (within $100 \mathrm{ft}[30 \mathrm{~m}]$ ) 


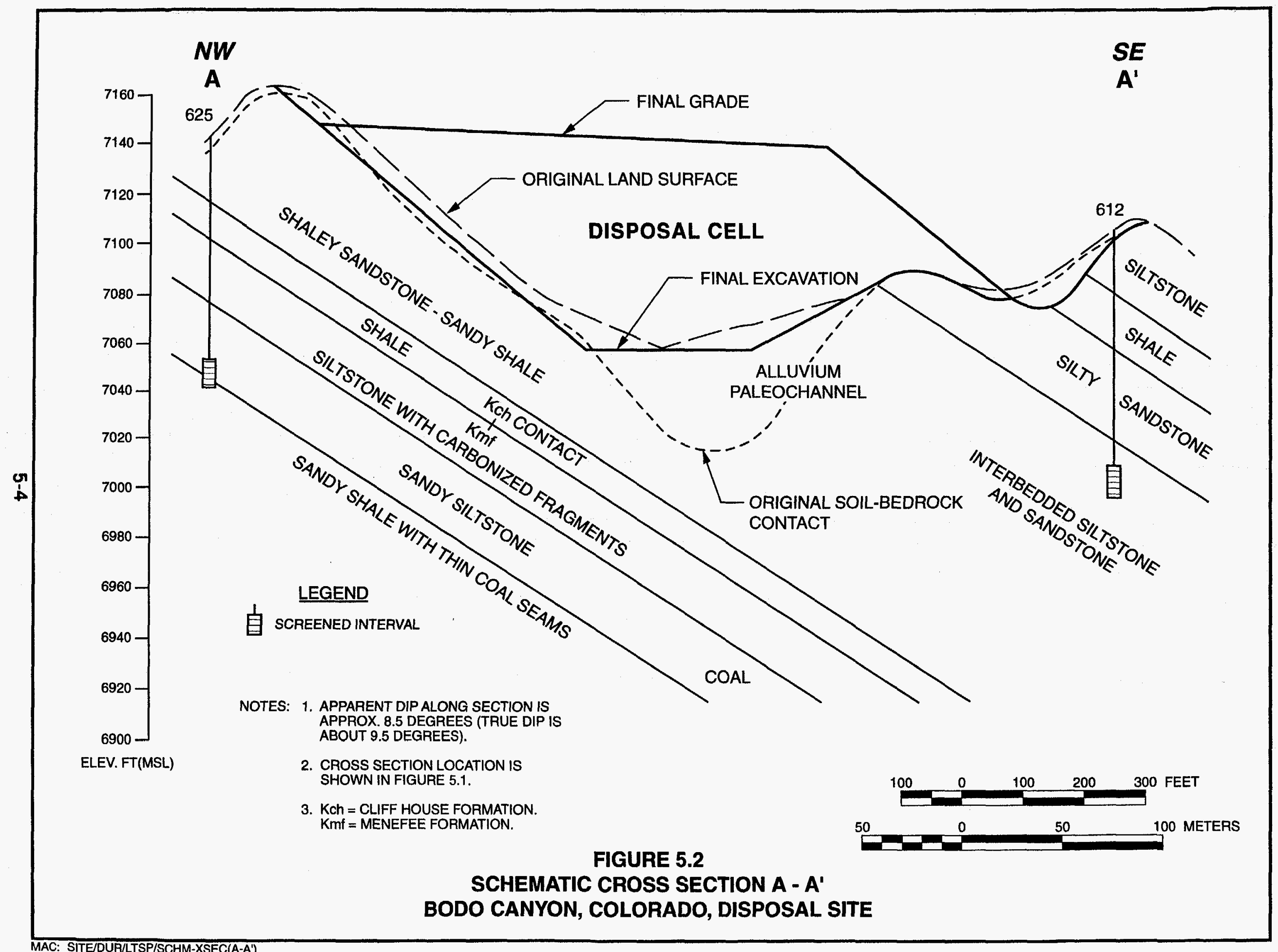




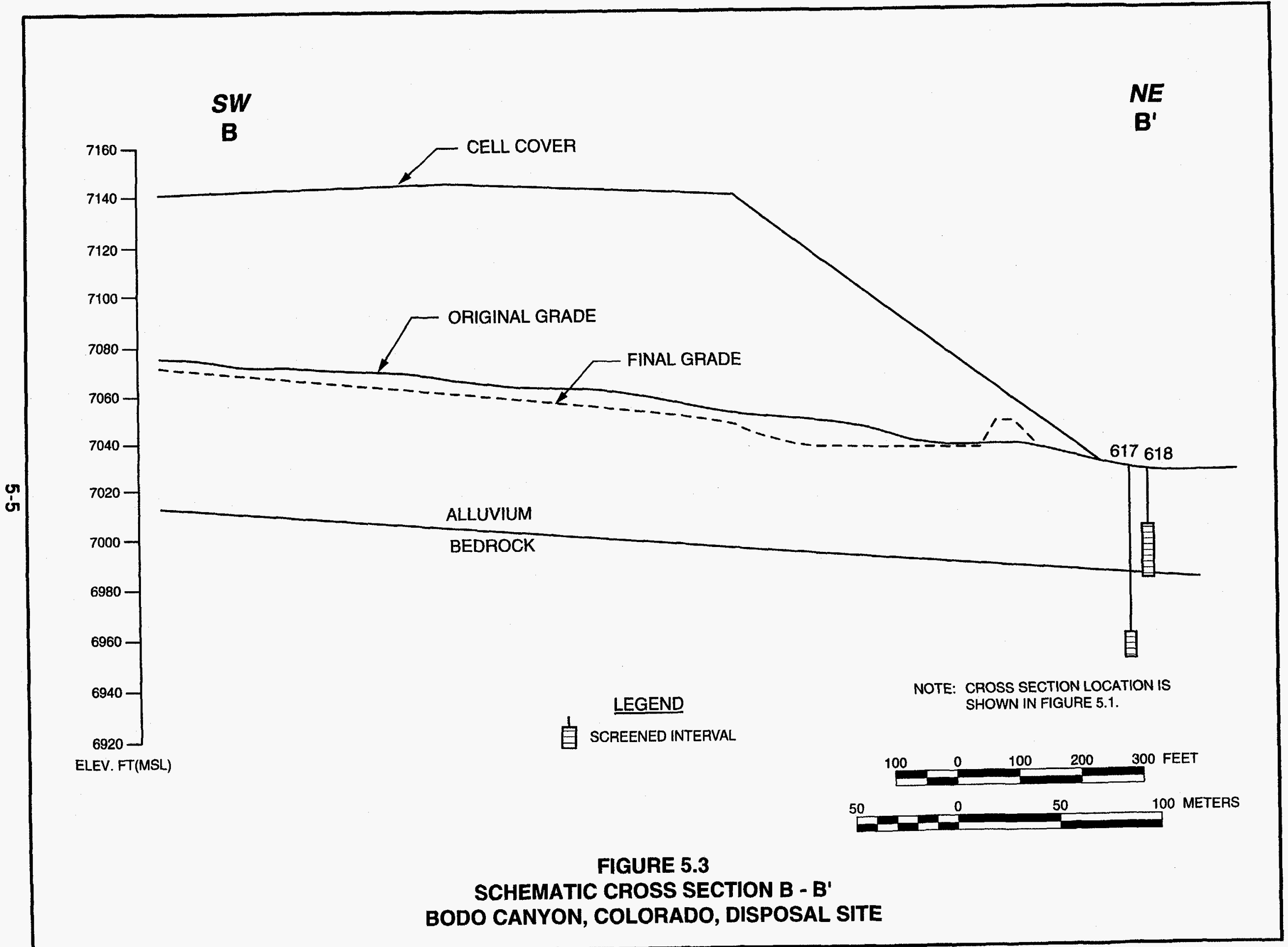


apparently occurs in different layers within the bedrock and these ground water bodies may have limited areal extent. Recharge of the near-surface ground water in the bedrock is probably only from local precipitation and is unrelated to the deeper, regional flow regime. Ground water in the shallow bedrock appears to flow both southeast, in the direction of the dip of the bedrock, and northeast, down the trend of the valley in the same direction as the ground water in the alluvium.

Three hydraulic gradients were calculated from three point-solutions used to define the southeastern direction of potential ground water flow in the bedrock. The average hydraulic gradient is $0.19 \mathrm{ft} / \mathrm{ft}$. The average potential ground water velocity was calculated using Darcy's law, assuming a porosity of 0.15 and the geometric mean of hydraulic conductivity $(0.07 \mathrm{ft}[.02 \mathrm{~m}]$ per day). The average potential ground water linear velocity to the southeast is $32 \mathrm{ft}(9.8 \mathrm{~m})$ per year in the bedrock aquifer (DOE, 1991).

\section{Ground water (alluvium)}

Shallow ground water occurs locally within the alluvium in the valley bottom. The depth to ground water prior to construction of the disposal cell varied seasonally and several boreholes in the mid- to upgradient areas beneath the disposal cell did not encounter water above the bedrock. Ground water in the shallow alluvium was encountered mostly northeast of the disposal cell, near well 606. During the wet season, ground water was at or near the ground surface. The hydraulic conductivity of the shallow alluvium in most of the valley averages approximately $0.13 \mathrm{ft}$ per day $\left(0.46 \times 10^{-4} \mathrm{~cm}\right.$ per second), although an aquifer test performed at the confluence of the paleochannel and the north arroyo gave a value of $32 \mathrm{ft}(10 \mathrm{~m})$ per day. Assuming a porosity of 0.25 and a gradient of 0.003 down the valley center, the rate of movement to the northeast will vary from approximately $0.6 \mathrm{ft}(0.2 \mathrm{~m})$ per year to about $140 \mathrm{ft}$ $(40 \mathrm{~m})$ per year. This amount of variability is not unusual for alluvium-filled valleys. For calculations of potential downward movement of ground water, the vertical conductivity is assumed to be one-third of the horizontal hydraulic conductivity.

The disposal cell fills more than 85 percent of the original valley. Prior to construction of the disposal cell, most of the alluvium in the western two-thirds of the valley was not saturated. The design of the cell, including the compacted soil beneath it and the extremely low-permeability radon and infiltration barriers on its top, prevents precipitation and snowmelt from percolating through the cell into the subsurface and recharging the ground water. As a result, the limited area of alluvial system saturation in the mid- to upgradient areas beneath the disposal cell are expected to dewater with time. 


\subsubsection{Monitor well network}

In 1995, 15 monitoring wells existed at the Bodo Canyon disposal site (Figure 5.1). These wells, their locations, depth of the screened interval, and number of times sampled are listed in Table 5.1.

\subsubsection{Background ground water quality}

Because of the limited area of alluvial system saturation under natural conditions and the desaturation expected in the alluvium beneath the disposal cell, the bedrock aquifer (also called the Cliff House/Menefee aquifer) is considered the uppermost aquifer at the Bodo Canyon site (DOE, 1991).

Background ground water quality in the bedrock aquifer has been determined from samples from nine monitor wells completed in the bedrock aquifer. These wells are located both upgradient and downgradient of the disposal cell (Table 5.1). Data collected from 1987 through 1994 are used to characterize background water quality. Although these data were collected prior to, during, and after tailings placement at the disposal site, these data are representative of natural background ground water for the following reasons. Prior to construction of the disposal cell, the disposal site was used as pastureland managed by the Bureau of Land Management. No mining or milling activities took place at the disposal site before placement of the cell. During placement of the cell, samples of the liner were collected and analyzed for chemical evidence of tailings solutions seeping through the scarified clay liner. No evidence for seepage into or through the scarified clay liner was found (DOE, 1991). Finally, notable changes in ground water quality have not been observed in monitor wells sampled prior to, during, and after cell construction.

Background ground water quality in the bedrock aquifer varies between wells, primarily because the amount of dissolved sulfate salts varies between wells. These salts are thought to be derived from the dissolution of natural gypsum in the aquifer. Total dissolved solids range from 670 to 7440 milligrams per liter (mg/L). Major anions include sulfate and/or bicarbonate. Sodium is generally the major cation. The ground waters are generally oxidizing; however, measured oxidation-reduction potentials vary in individual wells from reducing (as low as -353 millivolts [mV]) to oxidizing (up to $768 \mathrm{mV}$ ). Ground waters in the bedrock aquifer also range from alkaline (average $\mathrm{pH}$ of 8.9 in well 609) to acid (average pH of 4.9 in well 621 ). The acidic water in well 621 and in adjacent well 616 is thought to be due to the natural oxidation of pyrite (iron sulfide) in the aquifer. The naturally acidic water is associated with high levels of dissolved iron (up to $452 \mathrm{mg} / \mathrm{L}$ ), manganese (up to $6.04 \mathrm{mg} / \mathrm{L}$ ), sulfate (up to $4000 \mathrm{mg} / \mathrm{L}$ ) and sulfide (up to $16 \mathrm{mg} / \mathrm{L}$ ). Indicators of ground water contamination from tailings solutions (uranium, molybdenum, and selenium, as discussed in Section 5.2.3) are not present at levels above background in wells 621 and 616 . Trace constituents that have been detected at least once in background samples include antimony, arsenic, beryllium, cadmium, chromium, 
Table 5.1 Monitor wells at the Bodo Canyon, Colorado, disposal site

\begin{tabular}{|c|c|c|c|c|c|}
\hline \multirow[b]{2}{*}{ Well } & \multirow[b]{2}{*}{ Location } & \multicolumn{2}{|c|}{$\begin{array}{l}\text { Screened Interval (depth } \\
\text { below surface) }\end{array}$} & \multirow{2}{*}{$\begin{array}{c}\text { Year } \\
\text { sampled }\end{array}$} & \multirow[t]{2}{*}{$\begin{array}{c}\text { Number } \\
\text { of } \\
\text { sampling } \\
\text { rounds }\end{array}$} \\
\hline & & $(\mathbf{f t})$ & $(\mathrm{m})$ & & \\
\hline $\begin{array}{l}\text { Alluvial aquifer } \\
\text { DUR-03-0606 } \\
\text { DUR-03-0608 } \\
\text { DUR-03-0614 } \\
\text { DUR-03-0618 } \\
\text { DUR-03-0620 } \\
\text { DUR-03-0623 }\end{array}$ & $\begin{array}{l}\text { downgradient, NE } \\
\text { downgradient, NE } \\
\text { downgradient, NE } \\
\text { downgradient, NE } \\
\text { downgradient, NE } \\
\text { upgradient, North }\end{array}$ & $\begin{array}{l}14-34 \\
29-39 \\
22-42 \\
30-50 \\
29-49 \\
19-39\end{array}$ & $\begin{array}{l}4.3-10.4 \\
8.8-11.9 \\
6.7-12.8 \\
9.1-15.2 \\
8.8-14.9 \\
5.8-11.9\end{array}$ & $\begin{array}{l}87-94 \\
87-94 \\
89-93 \\
90-94 \\
90-94 \\
89-94\end{array}$ & $\begin{array}{r}20 \\
25 \\
13 \\
5 \\
3 \\
18\end{array}$ \\
\hline \multicolumn{6}{|c|}{ Bedrock aquifer (Cliff House/Menefee aquifer) } \\
\hline DUR-03-0605 & upgradient, NW & $36-56$ & $11.0-17.1$ & $87-94$ & 21 \\
\hline DUR-03-0607 & downgradient, South & $37-57$ & $11.3-17.4$ & $87-94$ & 20 \\
\hline DUR-03-0609 ${ }^{c}$ & downgradient, SE & $144-176$ & $43.9-53.6$ & $88-90$ & 7 \\
\hline $\begin{array}{l}\text { DUR-03-0611 } \\
\text { DUR-03-0613 }\end{array}$ & $\begin{array}{l}\text { downgradient, South } \\
\text { downgradient, SE }\end{array}$ & $\begin{array}{c}108-118 \\
68-78\end{array}$ & $\begin{array}{l}32.9-36.0 \\
20.7-23.8\end{array}$ & $\begin{array}{l}90-94 \\
89-90\end{array}$ & $\begin{array}{l}7 \\
2\end{array}$ \\
\hline DUR-03-0612 ${ }^{b}$ & downgradient, South & $98-108$ & $29.9-32.9$ & $89-94$ & 14 \\
\hline $\begin{array}{l}\text { DUR-03-0616 } \\
\text { DUR-03-0617 }\end{array}$ & $\begin{array}{l}\text { downgradient, NE } \\
\text { downgradient, NE }\end{array}$ & $\begin{array}{l}89-99 \\
80-90\end{array}$ & $\begin{array}{l}27.1-30.2 \\
24.4-27.4\end{array}$ & $\begin{array}{l}89-94 \\
-\end{array}$ & $\begin{array}{r}10 \\
0\end{array}$ \\
\hline $\begin{array}{l}\text { DUR-03-0619 } \\
\text { DUR-03-0621 }\end{array}$ & $\begin{array}{l}\text { downgradient, NE } \\
\text { downgradient, NE }\end{array}$ & $\begin{array}{l}79-89 \\
78-88\end{array}$ & $\begin{array}{l}24.1-27.1 \\
23.8-26.8\end{array}$ & $90-94$ & $\begin{array}{r}0 \\
18\end{array}$ \\
\hline DUR-03-0625 & upgradient, North & $89-99$ & $27.1-30.2$ & $89-94$ & 8 \\
\hline
\end{tabular}

${ }^{\mathbf{a} B a c k g r o u n d}$ well for routine screening monitoring.

boint-of-compliance well.

'Decommissioned well. 
Table 5.2 Summary of water quality data for tailings solutions, background ground water, and toe drain effluent, Bodo Canyon, Colorado, disposal site (Continued)

\begin{tabular}{|c|c|c|c|c|}
\hline Parameter & $\begin{array}{c}\text { Frequency of } \\
\text { detection }\end{array}$ & Minimum & Median & Maximum \\
\hline \multicolumn{5}{|l|}{ Sodium } \\
\hline Tailings & $15 / 15$ & 122 & 228 & 727 \\
\hline Background & $88 / 88$ & 105 & 336 & 1370 \\
\hline Toe drain & $1 / 1$ & - & 238 & - \\
\hline \multicolumn{5}{|l|}{ Sulfate } \\
\hline Tailings & $15 / 15$ & 1540 & 1710 & 2800 \\
\hline Background & $79 / 79$ & 23 & 925 & 4000 \\
\hline Toe drain & $1 / 1$ & - & 1770 & - \\
\hline \multicolumn{5}{|c|}{ Total dissolved solids } \\
\hline Tailings & $15 / 15$ & 2790 & 3250 & 5080 \\
\hline Background & $79 / 79$ & 932 & 2750 & 7440 \\
\hline Toe drain & $1 / 1$ & - & 3200 & - \\
\hline \multicolumn{5}{|c|}{ LISTED HAZARDOUS CONSTITUENTS (Table A and Appendix I, 40 CFR Part 192) } \\
\hline \multicolumn{5}{|l|}{ Antimony } \\
\hline Tailings & $0 / 0$ & - & NA & - \\
\hline Background & $9 / 46$ & $<0.003$ & $<0.003$ & $0.027^{a}$ \\
\hline Toe drain & $1 / 1$ & - & $<0.003$ & - \\
\hline \multicolumn{5}{|l|}{ Arsenic $^{b}$} \\
\hline Tailings & $15 / 15$ & 0.09 & 0.19 & 0.57 \\
\hline Background & $12 / 92$ & $<0.001$ & $<0.01$ & $0.03^{\mathrm{a}}$ \\
\hline Toe drain & $1 / 1$ & - & 0.34 & - \\
\hline \multicolumn{5}{|l|}{ Barium } \\
\hline Tailings & $0 / 15$ & $<0.10$ & $<0.10$ & $<0.10$ \\
\hline Background & $27 / 72$ & $<0.01$ & $<0.10$ & 0.90 \\
\hline Toe drain & $1 / 1$ & - & $<0.01$ & - \\
\hline \multicolumn{5}{|l|}{ Beryllium ${ }^{b}$} \\
\hline Tailings & $5 / 15$ & $<0.01$ & $<0.01$ & 0.16 \\
\hline Background & $5 / 52$ & $<0.005$ & $<0.01$ & 0.023 \\
\hline Toe drain & $1 / 1$ & - & $<0.01$ & - \\
\hline \multicolumn{5}{|l|}{ Cadmium ${ }^{b}$} \\
\hline Tailings & $15 / 15$ & 0.014 & 0.037 & 0.063 \\
\hline Background & $14 / 92$ & $<0.001$ & $<0.001$ & 0.019 \\
\hline Toe drain & $1 / 1$ & - & 0.019 & - \\
\hline
\end{tabular}


Table 5.2 Summary of water quality data for tailings solutions, background ground water, and toe drain effluent, Bodo Canyon, Colorado, disposal site (Continued)

\begin{tabular}{|c|c|c|c|c|}
\hline Parameter & $\begin{array}{c}\text { Frequency of } \\
\text { detection }\end{array}$ & Minimum & Median & Maximum \\
\hline $\begin{array}{l}\text { Chromium } \\
\text { Tailings } \\
\text { Background } \\
\text { Toe drain }\end{array}$ & $\begin{array}{c}5 / 15 \\
6 / 72 \\
1 / 1\end{array}$ & $\begin{array}{l}<0.01 \\
<0.01 \\
-\end{array}$ & $\begin{array}{l}<0.01 \\
<0.01 \\
<0.01\end{array}$ & $\begin{array}{l}0.26 \\
0.12 \\
-\end{array}$ \\
\hline $\begin{array}{l}\text { Cyanide } \\
\text { Tailings } \\
\text { Background } \\
\text { Toe drain }\end{array}$ & $\begin{array}{l}0 / 10 \\
1 / 30 \\
0 / 0\end{array}$ & $\begin{array}{l}<0.01 \\
<0.01 \\
-\end{array}$ & $\begin{array}{l}<0.01 \\
<0.01 \\
\text { NA }\end{array}$ & $\begin{array}{c}<0.01 \\
0.18 \\
-\end{array}$ \\
\hline $\begin{array}{l}\text { Lead } \\
\text { Tailings } \\
\text { Background } \\
\text { Toe drain }\end{array}$ & $\begin{array}{c}7 / 15 \\
9 / 88 \\
1 / 1\end{array}$ & $\begin{array}{l}<0.01 \\
<0.001 \\
-\end{array}$ & $\begin{array}{l}<0.01 \\
<0.01 \\
<0.01\end{array}$ & $\begin{array}{l}0.02 \\
0.02^{\mathrm{a}} \\
-\end{array}$ \\
\hline $\begin{array}{l}\text { Mercury } \\
\text { Tailings } \\
\text { Background } \\
\text { Toe drain }\end{array}$ & $\begin{array}{c}5 / 15 \\
4 / 68 \\
1 / 1\end{array}$ & $\begin{array}{l}<0.0002 \\
<0.0002 \\
-\end{array}$ & $\begin{array}{l}<0.0002 \\
<0.0002 \\
<0.0002\end{array}$ & $\begin{array}{l}<0.0004 \\
<0.0004 \\
-\end{array}$ \\
\hline $\begin{array}{l}\text { Molybdenum }{ }^{\circ} \\
\text { Tailings } \\
\text { Background } \\
\text { Toe drain }\end{array}$ & $\begin{array}{c}15 / 15 \\
25 / 92 \\
1 / 1\end{array}$ & $\begin{array}{r}0.81 \\
<0.01 \\
-\end{array}$ & $\begin{array}{r}1.73 \\
<0.01 \\
1.69\end{array}$ & $\begin{array}{l}3.98 \\
0.22 \\
-\end{array}$ \\
\hline $\begin{array}{l}\text { Net gross alpha } \\
\text { Tailings } \\
\text { Background } \\
\text { Toe drain }\end{array}$ & $\begin{array}{c}1 / 15 \\
48 / 82 \\
0 / 0\end{array}$ & $\begin{array}{l}0.0 \\
0.0 \\
-\end{array}$ & $\begin{array}{r}0.0 \\
2.9 \\
\text { NA }\end{array}$ & $\begin{array}{r}67 \\
35 \\
-\end{array}$ \\
\hline $\begin{array}{l}\text { Nickel }^{\mathrm{b}} \\
\text { Tailings } \\
\text { Background } \\
\text { Toe drain }\end{array}$ & $\begin{array}{c}3 / 5 \\
7 / 58 \\
1 / 1\end{array}$ & $\begin{array}{l}<0.04 \\
<0.01 \\
-\end{array}$ & $\begin{array}{c}0.04 \\
<0.04 \\
0.060\end{array}$ & $\begin{array}{l}0.07 \\
0.07 \\
-\end{array}$ \\
\hline $\begin{array}{l}\text { Nitrate } \\
\text { Tailings } \\
\text { Background } \\
\text { Toe drain }\end{array}$ & $\begin{array}{c}9 / 15 \\
38 / 87 \\
1 / 1\end{array}$ & $\begin{array}{l}<1.0 \\
<0.1 \\
-\end{array}$ & $\begin{array}{r}1.6 \\
<1.0 \\
<0.1\end{array}$ & $\begin{array}{r}22 \\
43 \\
-\end{array}$ \\
\hline $\begin{array}{c}\text { Radium-226 } \\
\text { Tailings } \\
\text { Background } \\
\text { Toe drain }\end{array}$ & $\begin{array}{c}15 / 15 \\
12 / 90 \\
1 / 1 \\
\end{array}$ & $\begin{array}{r}5.9 \\
<0.1 \\
-\end{array}$ & $\begin{array}{r}9.9 \\
<1.0 \\
14.0 \\
\end{array}$ & $\begin{array}{c}18 \\
2.0 \\
-\end{array}$ \\
\hline
\end{tabular}


Table 5.2 Summary of water quality data for tailings solutions, background ground water, and toe drain effluent, Bodo Canyon, Colorado, disposal site (Concluded)

\begin{tabular}{|c|c|c|c|c|}
\hline Parameter & $\begin{array}{c}\text { Frequency of } \\
\text { detection }\end{array}$ & Minimum & Median & Maximum \\
\hline $\begin{array}{l}\text { Radium-228 } \\
\text { Tailings } \\
\text { Background } \\
\text { Toe drain }\end{array}$ & $\begin{array}{c}0 / 15 \\
20 / 90 \\
1 / 1\end{array}$ & $\begin{array}{c}<1.0 \\
<0.9 \\
-\end{array}$ & $\begin{array}{r}<1.0 \\
<1.0 \\
1.0\end{array}$ & $\begin{array}{l}<1.0 \\
15 \\
-\end{array}$ \\
\hline $\begin{array}{l}\text { Selenium } \\
\text { Tailings } \\
\text { Background } \\
\text { Toe drain }\end{array}$ & $\begin{array}{c}15 / 15 \\
18 / 92 \\
1 / 1\end{array}$ & $\begin{array}{r}0.045 \\
<0.001 \\
-\end{array}$ & $\begin{array}{r}0.13 \\
<0.005 \\
0.093\end{array}$ & $\begin{array}{l}0.41 \\
0.042^{a}\end{array}$ \\
\hline $\begin{array}{l}\text { Silver }^{b} \\
\text { Tailings } \\
\text { Background } \\
\text { Toe drain }\end{array}$ & $\begin{array}{c}7 / 15 \\
2 / 68 \\
1 / 1\end{array}$ & $\begin{array}{l}<0.01 \\
<0.01 \\
-\end{array}$ & $\begin{array}{r}<0.01 \\
<0.01 \\
0.01\end{array}$ & $\begin{array}{l}0.07 \\
0.03 \\
-\end{array}$ \\
\hline $\begin{array}{l}\text { Thallium } \\
\text { Tailings } \\
\text { Background } \\
\text { Toe drain }\end{array}$ & $\begin{array}{c}0 / 15 \\
1 / 35 \\
1 / 1\end{array}$ & $\begin{array}{l}<0.01 \\
<0.01 \\
-\end{array}$ & $\begin{array}{l}<0.01 \\
<0.01 \\
<0.01\end{array}$ & $\begin{array}{c}<0.01 \\
0.01^{\mathrm{a}} \\
-\end{array}$ \\
\hline $\begin{array}{l}\text { Uranium } \\
\text { Tailings } \\
\text { Background } \\
\text { Toe drain }\end{array}$ & $\begin{array}{c}15 / 15 \\
53 / 89 \\
1 / 1\end{array}$ & $\begin{array}{l}1.5 \\
<0.001 \\
-\end{array}$ & $\begin{array}{l}4.5 \\
0.001 \\
4.0\end{array}$ & $\begin{array}{l}22 \\
0.077 \\
-\end{array}$ \\
\hline $\begin{array}{l}\text { Vanadium }^{b} \\
\text { Tailings } \\
\text { Background } \\
\text { Toe drain }\end{array}$ & $\begin{array}{c}5 / 5 \\
27 / 79 \\
1 / 1\end{array}$ & $\begin{array}{c}5.7 \\
<0.01 \\
-\end{array}$ & $\begin{array}{l}11 \\
<0.01 \\
14\end{array}$ & $\begin{array}{l}14 \\
0.06 \\
-\end{array}$ \\
\hline
\end{tabular}

${ }^{\mathrm{a}}$ Maximum observed above detection.

${ }^{b}$ Constituents in tailings having concentrations significantly greater than background (at the 95 percent confidence level).

Notes:

1. All data in milligrams per liter except for the following: net gross alpha, radium-226, and radium-228 (in picocuries per liter); $\mathrm{pH}$ in standard units; oxidation-reduction potential in millivolts.

2. Data for background are from wells completed in the bedrock aquifer (monitor wells 605, 607, $609,611,612,613,616,617,621$, and 625). Data are for filtered samples collected from 1987 through 1994.

3. Data for tailings solutions are from wells completed within the disposal cell (monitor wells 200 , 201, 202, 203, and 204). Data are for filtered samples collected from 1987 through 1990.

4. Data for the toe drain effluent from Attachment 3, Table 3.22 of the RAP (DOE, 1991).

5. Dash indicates not applicable (only one measurement available).

NA - not analyzed. 
material. These reactions will reduce concentrations to background levels before the bedrock aquifer is reached.

Several constituents listed in Table A or Appendix I of 40 CFR Part 192 either were not detected in the tailings or toe drain effluent lantimony, barium, cyanide, net gross alpha, and thallium) or occurred at levels equal to or less than levels found in background ground waters based on statistical testing (lead, nitrate, and radium-228). These constituents are not designated as hazardous constituents at the Bodo Canyon disposal site.

\subsubsection{Concentration limits for hazardous constituents}

Concentration limits for long-term monitoring of the disposal cell (Table 5.3) were established following EPA guidance (EPA, 1992). On pages 49 to 56, this EPA document endorses the use of tolerance intervals for detecting contamination above background in one or more downgradient wells. A tolerance interval is designed to contain all but a small percentage of all future measurements from wells accessing uncontaminated water. Therefore, repeated exceedances of the upper tolerance limit present statistical evidence of contamination.

Due to inherent uncertainties at the Bodo Canyon site concerning the geographic and statistical distribution of naturally occurring constituents in the ground water, a nonparametric approach was used to determine a tolerance interval for the hazardous constituents. Using this approach, the upper tolerance limit is the maximum observed concentration in bedrock well samples collected between 1987 and 1994. At the Durango site, the maximum concentrations are based on databases ranging from 52 measurements for beryllium up to 92 measurements for cadmium, chromium, and selenium. There is 95 percent confidence the maximum observed concentration of each constituent represents a level that will exceed background no more than 5 percent of the time. Therefore, using the maximum observed concentration as a concentration limit for long-term ground water monitoring produces reasonable protection against false positive results from random background variation.

Regulations allow the concentration limit for hazardous constituents on Table 1 of Subpart $A$ be set at the background or maximum concentration limit (MCL), whichever is greater. Therefore, the proposed concentration limits for hazardous constituents listed in Table 5.3 represent the larger of the maximum observed concentration and the UMTRA Project MCL for constituents with established MCLs.

\subsection{GROUND WATER PROTECTION MONITORING PLAN}

The ground water protection monitoring plan includes monitoring the uppermost aquifer and analyzing ground water samples from a series of monitor wells downgradient from the disposal cell at the point of compliance (POC) and upgradient from the disposal cell as background. This direct monitor well 
Table 5.3 Proposed concentration limits for hazardous constituents in tailings solutions, Bodo Canyon, Colorado, disposal site

\begin{tabular}{|c|c|c|c|c|c|}
\hline \multirow[b]{2}{*}{ Constituent } & \multirow[b]{2}{*}{ MCL } & \multirow{2}{*}{$\begin{array}{l}\text { Tailings } \\
\text { pore fluid } \\
\text { median }\end{array}$} & \multicolumn{2}{|c|}{$\begin{array}{c}\text { Cliff House/Menefee } \\
\text { background ground } \\
\text { water }\end{array}$} & \multirow{2}{*}{$\begin{array}{c}\text { Proposed } \\
\text { concentration } \\
\text { limit }^{\circ}\end{array}$} \\
\hline & & & maximum & Median" & \\
\hline Arsenic & 0.05 & 0.19 & 0.03 & $<0.01$ & $0.05^{b}$ \\
\hline Cadmium & 0.01 & 0.037 & 0.019 & $<0.001$ & $0.019^{c}$ \\
\hline Chromium & 0.05 & $<0.01$ & 0.12 & $<0.01$ & $0.12^{c}$ \\
\hline Mercury & 0.002 & $<0.0002$ & 0.0004 & $<0.0002$ & $0.002^{b}$ \\
\hline Molybdenum & 0.1 & 1.73 & 0.22 & $<0.01$ & $0.22^{c}$ \\
\hline Radium-226 and -228 & 5.0 & 10.1 & 15 & $<2.0$ & $15.0^{c}$ \\
\hline Selenium & 0.01 & 0.13 & 0.042 & $<0.005$ & $0.042^{c}$ \\
\hline Silver & 0.05 & $<0.01$ & 0.03 & $<0.01$ & $0.05^{b}$ \\
\hline Uranium & 0.044 & 4.5 & 0.077 & 0.001 & $0.077^{c}$ \\
\hline Beryllium & None & $<0.01$ & 0.023 & $<0.01$ & $0.023^{d}$ \\
\hline Nickel & None & 0.04 & 0.07 & $<0.04$ & $0.07^{d}$ \\
\hline Vanadium & None & 11 & 0.06 & $<0.01$ & $0.06^{d}$ \\
\hline
\end{tabular}

an Cliff House/Menefee uppermost aquifer at point of compliance.

boserved maximum in background less than maximum concentration limit.

'Observed maximum background greater than maximum concentration limit.

${ }^{d}$ Observed maximum in background.

Note: All units reported in milligrams per liter except radium-226 and -228 , which are reported in picocuries per liter. 
network is discussed below (Section 5.2.1). Performance monitoring frequency is outlined in Section $\mathbf{5}$.2.2 below.

All aspects of the ground water monitoring plan will be conducted in accordance with accepted industry QA practices, including directives in DOE Orders 5700.6C, Quality Assurance, and 5400.1, General Environmental Protection Program.

\subsubsection{Direct ground water monitoring network}

Ground water samples will be collected from upgradient monitor well 605 and downgradient POC wells 607 and 612 southeast of the disposal cell, and well 621 to the northeast (Figure 5.1 and Table 5.1).

Ground water quality and water level data will also be monitored in background alluvial well 623 and downgradient alluvial well 608. They will be sampled at the same frequency as POC wells until the DOE determines the alluvium has been effectively desaturated (DOE, 1991). They also will be monitored for the same constituents as the POC wells (Sections 5.2.3 and 5.2.4).

\subsubsection{Sampling frequency}

As described in the RAP, the sampling schedule factors in variables such as background ground water quality, the geochemistry of the tailings pore fluid solution, horizontal and vertical ground water flow rates, possible seasonal variations in ground water, and risk to human health and the environment (DOE, 1991). Ground water levels will be measured before each well is sampled.

Upgradient and downgradient monitor wells were sampled semiannually from 1990 to 1995. Sampling will be conducted annually, beginning in 1996. For consistency, this sampling will be conducted at approximately the same time each year. This frequency may be changed, upon approval from the NRC, based on site-specific conditions and the effectiveness of the remedial action as determined through the ongoing monitoring program (EPA, 1988).

\subsubsection{Screening monitoring and exceedance validation}

During the established ground water monitoring period (see Section 5.2.2) screening monitoring will be conducted to observe possible changes in ground water quality and to assess compliance with the ground water protection standards. Screening monitoring includes routine water-quality data collection, data evaluation, and possible resampling. It also includes analyzing constituents that are indicative of general water quality and hazardous constituents that are reliable indicators of contamination (Table 5.4). General water quality indicators include $\mathrm{pH}$, electrical conductivity, temperature, alkalinity, oxidation-reduction potential, and major anions and cations (Table 5.4). These data provide general information for interpreting potential changes in ground water quality. Screening 
Table 5.4 Parameters to be measured during screening monitoring at the Bodo Canyon, Colorado, disposal site

Indicator parameters for detecting ground water contamination

Molybdenum

$0.22^{\mathrm{a}}$

Selenium

$0.042^{\mathrm{a}}$

Uranium

$0.077^{\mathrm{a}}$

Field parameters for monitoring ground water quality

Alkalinity

None

Oxidation-reduction potential

None

pH

None

Specific conductivity

None

Temperature

None

Major anions and cations for monitoring ground water quality

Calcium

None

Chloride

None

Iron

None

Magnesium

None

Manganese

None

Potassium

None

Sodium

None

Sulfate

None

Total dissolved solids

None

All proposed concentration limits are in milligrams per liter and are based upon maximum observed values in background. 
parameters indicative of contamination are those that 1) are known to be present in the tailings solutions at levels statistically greater than background levels, 2) are present at much higher levels in the tailings solutions than in background, 3) display low variability in background, and 4) are mobile in the ground water environment. The parameters that best meet the first three criteria are arsenic, molybdenum, selenium, uranium, and vanadium. Of these, attenuation batch experiments indicate that subsurface sediments beneath the Bodo Canyon disposal cell will adsorb all the vanadium and most of the arsenic in solution, some selenium and uranium, and a small amount of molybdenum (DOE, 1991). Therefore, molybdenum, selenium, and uranium are the most reliable indicator parameters of ground water contamination at the Bodo Canyon site and will be monitored during screening monitoring.

Exceedances in concentration limits for molybdenum, selenium, or uranium are evaluated on a well-by-well basis. If an MCL listed in Table 5.3 is exceeded, the well will be resampled within 1 year for all screening monitoring parameters (Table 5.4). If the resampling indicates a second exceedance of concentration limits for a parameter, the appropriate steps will be taken, as specified in Section 5.3.2 of the Guidance for Implementing the UMTRA Project Long-Term Surveillance Program (DOE, 1992a).

\subsubsection{Evaluative monitoring}

When sampling, evaluating, and resampling during screening monitoring does not eliminate the disposal cell as the cause for a water-quality exceedance, evaluative ground water monitoring, additional evaluation, and fieldwork may be required. Evaluative ground water monitoring will involve sampling ground waters from POC and possibly other wells, and analyzing for the entire suite of hazardous constituents identified in Table $\mathbf{5 . 3}$ to determine if additional hazardous constituents exceed the proposed concentration limits. Data and fieldwork will be evaluated further to determine if the disposal cell is the cause of an exceedance and if so, its nature and extent. Evaluative monitoring may involve the procedures described in Section 5.3 of the Guidance for Implementing the UMTRA Project Long-Term Surveillance Program (DOE, 1992a).

\subsubsection{Indirect monitoring}

The DOE will directly monitor ground water at the disposal site (see Section 5.2.11. If screening and evaluative monitoring indicate a change in ground water quality attributable to the disposal cell design, the need for indirect monitoring will be assessed.

If evaluative monitoring indicates the performance of the disposal cell is the cause of an exceedance, it may be necessary to monitor the cover, the tailings, the subsoils, or a combination of components. Some indirect methods that may be applicable to monitoring changes in moisture content in the disposal cell include core sampling to determine gravimetric water content, neutron moisture 
monitoring, time-domain reflectometry, heat dissipation probes, or cross-hole topography. Any indirect monitoring instrumentation that may be required will be installed in accordance with the appropriate standard operating procedures (SOP) or best management practices. Specific monitoring strategies and instrumentation will be selected in consultation with the NRC.

\subsection{CORRECTIVE ACTION}

The EPA standards (40 CFR $\$ 192.04(\mathrm{c})$ ) require implementation of a corrective action program within 18 months of verification of an established concentration limit exceedance for one or more of the monitored constituents. The goal of the corrective action program is to restore the disposal cell to its design specifications. If corrective action is determined necessary, the DOE will prepare and submit a corrective action plan for NRC review (a copy of this plan also will be transmitted to the CDPHE). The plan will include a monitoring plan to demonstrate the effectiveness of the corrective action, which the DOE will implement after consultation with the NRC and the CDPHE.

\subsection{DATA VALIDATION AND QUALITY ASSURANCE}

The UMTRA Project Team has established SOPs for monitor well installation and development, water and soil sampling, sample preservation and transport, field procedures, chain of custody samples for laboratory analyses, acquisition protocols, and validating and managing analytical data. All aspects of ground water monitoring are conducted in accordance with these procedures, which are updated regularly to reflect changes in industry standards, best management practices, and guidance from the DOE or EPA. Ground water monitoring at the Bodo Canyon disposal site will remain the responsibility of the DOE until the site comes under the NRC general license. The QA procedures described in this section are consistent with the RCRA Ground Water Monitoring Technical Enforcement Guidance Document (EPA, 1986). Sections 5.61 and 5.6 .4 in Guidance for Implementing the UMTRA Project Long-Term Surveillance Program (DOE, 1992a) summarize standard OA procedures for water sampling and analytical $Q C$ and $Q A$ and data validation.

\subsection{REPORTING}

Data and results of the ground water monitoring plan will be described in an evaluation report once every 5 years to the NRC and the state of Colorado. The 5-year report will include the following information:

- Water-quality data, water level data, and other data collected during the reporting period.

- A table comparing water quality indicators to concentration limits.

- A summary of exceedances of concentration limits and the exceedance validation criteria. 
- A summary of all resampling, evaluative monitoring, or corrective action required during the reporting period.

- A discussion of significant trends or anomalies in the water quality, other data, or changes in the local hydrologic setting.

- A discussion of new wells or indirect monitoring stations that were installed, including the rationale for their installation, and all completion data.

- All completed field and laboratory forms.

The DOE is responsible for preparing the evaluation reports every 5 years until the GJPO assumes responsibility for a licensed disposal site. 


\subsection{ANNUAL SITE INSPECTIONS}

Inspections of the Bodo Canyon disposal site will be documented in an inspection report to record any changes to the disposal cell and site over time and to identify potential problems before the need for extensive maintenance, repairs, or corrective action. Fundamental to the inspections will be the detection and documentation of progressive change caused by slow-acting natural processes. The findings from these inspections will be compared to the initial baseline conditions to provide a basis for future inspections. The following three types of site inspections should be performed:

- Annual or scheduled site inspections.

- Follow-up inspections.

- Contingency inspections.

Each site inspection must be documented in a report that identifies the findings of the inspection. Copies of the report will be submitted to the NRC and CDPHE and will be placed in the Durango permanent site file. Annual scheduled site inspection reports will be completed and submitted to the NRC within 90 days of the last UMTRA Project site inspection of that calendar year. Follow-up or contingency inspection reports must be submitted to the NRC within 60 days of the NRC's receiving the annual inspection report and within 60 days after any other type of inspection.

\subsection{INSPECTION FREQUENCY}

The Bodo Canyon disposal site will be inspected annually for the first 5 years after licensing. At the end of the 5-year period, the GJPO will evaluate the need to continue annual inspections, basing its recommendation on an evaluation of the annual reports and any other reports filed for maintenance or unscheduled events. If it is determined that less frequent inspections would be sufficient, the GJPO will modify the LTSP and submit it to the NRC for approval and to the state of Colorado for review. Subsequent inspections will be considered scheduled site inspections.

\subsection{INSPECTION TEAM}

The inspection team will consist of a chief inspector and one or more assistants. The chief inspector will be a geotechnical engineer, a civil engineer, or an engineering geologist knowledgeable in the processes that could adversely affect the site (e.g., geomorphic agents of change).

When an inspection team is needed for follow-up or assessment inspections, the team will include additional technical experts appropriate to the problems under investigation. 


\subsection{PREPARATION FOR INSPECTION}

Before each inspection, inspectors will complete the following tasks:

- Review the LTSP, the permanent site file, previous site-inspection reports and maps, and all maintenance or corrective action reports.

- Prepare a site-inspection checklist based on previous inspections or repairs, and incorporate any needed modifications.

- Verify and update the names and telephone numbers of all parties with whom access or notification agreements have been executed.

- Verify the DOE 24-hour telephone number and appropriate agency telephone numbers and contacts; arrange to modify the entrance sign, as needed.

- Schedule the site inspection.

- Assemble all equipment needed for the inspection.

- Adjust the Brunton compass's magnetic declination for that of the Durango area (approximately 11 degrees east of true north).

- Notify the NRC, the state of Colorado, and adjacent landowners for their possible attendance at the inspection. Names and addresses of adjacent landowners are available in the Durango permanent site file at the GJPO.

\subsection{SITE INSPECTION AND INSPECTION CHECKLIST}

The site inspection will cover the disposal site area, the disposal cell, and the immediate off-site areas. All site inspection activities and observations should be recorded and described using the as-built drawings, initial site inspection checklist (Attachment 5), site inspection map, a field notebook, and photographs. Observations and photographic stations should be recorded on the field maps. After the inspection is complete, these maps should be drafted and kept in the Durango permanent site file.

The initial site inspection checklist (Attachment 6) is a guideline for the inspectors. After each inspection is complete, the checklist will be revised to include new information or to delete items that are no longer pertinent. Revisions to the checklist will be documented in the inspection report.

A photographic record of the disposal site inspection must be maintained. Site conditions should be documented by ground photographs to record developing trends and to enable the DOE to evaluate the need for and extent of future activities. If possible, any site feature or condition requiring inspectors to make a written comment, explanation, or description will be photographed. A site inspection photo log will be used to record the photographs (Attachment 5). All 
features will be photographed and recorded as specified in Section 3.4. The inspectors may determine the number of photographs, the view angles, and lenses used to ensure that sufficient photographs are taken for agency review.

\subsubsection{Off-site areas}

The area within a maximum $0.25 \mathrm{mi}(0.40 \mathrm{~km})$ from the center of the disposal site will be surveyed for evidence of land use changes that indicate increased human activity. New roads or paths, changes in vegetation, and relevant geomorphic features like gullies or aeolian formations, any of which could initiate site-threatening erosion, also will be observed.

\subsubsection{On-site areas}

The integrity of the disposal cell will be evaluated from a series of transects walked around the perimeter; along the base, crest, and sideslopes; and in and around the diversion channels. Sufficient transects must be walked so that the disposal cell is thoroughly covered and inspected. Diagonal transects of the crest will be made, and the edge of the crest will be walked. Additional transects, at approximately $50-y d(46-\mathrm{m})$ intervals, will be walked along the sideslopes. Transects along the entire length of each diversion channel will be made to determine if the channels are functioning and can be expected to continue to function as designed.

At a minimum, the site perimeter and site area transects will be monitored for damage to or disturbance of the following features:

- Site perimeter roads.

- Fences, gates, and locks.

- Permanent site-surveillance features.

- Ground water monitor wells.

- Site area vegetation or volunteer plant growth.

- Soil or rock cover (e.g., sedimentation or erosion).

The complete length of transects along the engineered component (diversion channels, cell sideslopes, cell crest, and cover) will be walked and examined for evidence of the following:

- Structural instability resulting from differential settlement, subsidence, cracking, sliding, or creep.

- Erosion as evidenced by developing rills or gullies.

- Sedimentation or debris.

- Rapid rock cover deterioration caused by weathering or erosion.

- Removal of rock or other disposal cell material. 
- Seepage.

- Intrusion (inadvertent or deliberate) by humans or animals.

- Volunteer plant growth.

\subsection{MODIFYING PROCESSES}

Modifications caused by natural processes may be observed and noted on the topslopes and the lower portions of the sideslopes of the disposal cell. These processes include gullying, headward erosion, cracking, landslides, creep, dissemination, deflation, animal or plant intrusion, and natural events (e.g., tornadoes or earthquakes). Modifications caused by engineered components of the disposal cell most likely will result in plant and animal intrusion.

Inadvertent or casual intrusion by humans or animals may occur because the site is not enclosed by a fence; therefore, evidence of cover removal, vandalism to signs and monuments, or the presence of well-established trails will be described in detail. Continued intrusion may require more active measures to control site access.

If new conditions requiring monitoring or immediate action are discovered during the inspection, the inspection report should describe the problem and when appropriate, recommend follow-up action.

\subsection{VEGETATION}

\subsubsection{Planned vegetation}

The top of the disposal cell is a vegetative cover and the uppermost layer consists of a 6-inch $(152 \mathrm{~mm})$ rock/soil matrix. A 2.5-ft $(0.76 \mathrm{~m})$ rooting medium/frost protection material layer was placed on top of the biointrusion material layer (type A riprap).

The soil was fertilized with a standard commercial grade fertilizer consisting of an nitrogen-phosphorus-potassium ratio of 2 to 1 to 1 or higher. The amount placed averaged 80 pounds per acre $(\mathrm{lb} / \mathrm{ac})(90 \mathrm{~kg} / \mathrm{ha})$. Weed-free straw mulch was placed at 2 tons ( 4.5 metric tonnes) per acre.

Prior to seed application, the top of the disposal cell was disced to ensure that 6 inches $(152 \mathrm{~mm}) \mathrm{rock} / \mathrm{soil}$ matrix was loose and friable, pursuant to seeding specifications. All seeding was accomplished with a range land drill set at 0.2 to 0.4 inches $(5$ to $10 \mathrm{~mm}$ ) beneath the surface.

The topslope was planted with the following plant seed poundage:
Smooth brome
$4.1 \mathrm{lb} / \mathrm{ac}(4.6 \mathrm{~kg} / \mathrm{ha})$
Kentucky bluegrass
$3.4 \mathrm{lb} / \mathrm{ac}(3.8 \mathrm{~kg} / \mathrm{ha})$ 
Western wheatgrass

Blue grama

Galleta

Total
$3.9 \mathrm{lb} / \mathrm{ac}(4.4 \mathrm{~kg} / \mathrm{ha})$

$3.65 \mathrm{lb} / \mathrm{ac}(4.1 \mathrm{~kg} / \mathrm{ha})$

$1.95 \mathrm{lb} / \mathrm{ac}(2.2 \mathrm{~kg} / \mathrm{ha})$

$17.0 \mathrm{lb} / \mathrm{ac}(19.1 \mathrm{~kg} / \mathrm{ha})$

A plant specialist or other qualified person will periodically participate in site inspections. If the inspection does not coincide with the general growing season, the plant specialist may conduct a separate inspection at a more favorable time.

\subsubsection{Volunteer plant orowth}

Volunteer plant growth includes plants growing where none were planned, such as in rock-lined drainage ditches, or unwanted plant species growing on the vegetated topslope of the disposal cell.

A follow-up inspection by a plant specialist may be required if an inspection team reports woody plant species such as big sagebrush growing on the vegetative cover. The growth of woody species on the vegetative cover is expected to minimize after the grass cover becomes established. Woody plants and other unwanted plant species may be eliminated from the cover by selective spraying or mechanical removal.

Based on results of the UMTRA Project plan biointrusion study (DOE, 1995), a volunteer plant root-to-shoot ratio of 1.0 to 1 should be used unless site-specific plant data indicate otherwise. Based on a root-to-shoot ratio of 1.0 to 1 , an unwanted plant species must be removed when its shoot height equals or exceeds $3.5 \mathrm{ft}(1.1 \mathrm{~m})$ from the base of the plant.

\subsection{SITE INSPECTION MAP}

A new site inspection map will be prepared after each scheduled inspection using the disposal site map (Plate 1) as a base. This map must include the following:

- Inspection traverses.

- Photograph locations.

- Locations and descriptions of new, anomalous, or unexpected features.

- Features identified during previous inspections for observation or monitoring.

- Inspection date.

\subsection{REPORTING REQUIREMENTS}

Upon completion of the field inspection, Section $D$ of the initial site inspection checklist (Attachment 6) must be completed and the certification statement must be signed by the GJPO chief inspector. Overlays for the as-built drawings or revised drawings will be developed, noting any potential problems or other 
site conditions requiring attention. The revised drawings will be labeled with the date and type of site inspection.

All photographs must be logged on a site inspection photo log (Attachment 5). A separate photo log should be completed for each roll of exposed film, with an entry for each photograph. The completed photo logs should be attached to the inspection checklist and paginated accordingly.

Documentary evidence of anomalous, new, or unexpected conditions or situations must be included to record developing trends and to enable the responsible agency to make reasonable decisions concerning follow-up inspections, custodial maintenance and/or repair, and corrective action. Photographs may be considered documentation.

A site inspection report including the following information will be completed after every routine site inspection:

- Narrative of site inspection, including results, conclusions, and recommendations.

- Site inspection checklist and relevant supporting documentation.

- Site inspection map and other drawings, maps, or figures used during the site inspection.

- Inspection photographs and photo log sheet.

- Recommendations for additional follow-up inspections or custodial maintenance and/or repair, if required.

- Follow-up or contingency inspection reports, if required.

- Custodial maintenance and/or repair report and certification, if required.

- Inspection certification.

- Ground water monitoring data and analyses, if applicable.

The inspection report also will detail observed modifying features, describe problems, and provide measurements, photographs, and an assessment of possible impacts. The description of the modifying process will include information such as the following:

- Extent of area affected.

- Number, spacing, length, depth, and width of features (e.g., gullies).

- Related erosional features.

- Patterns of occurrence. 
- Plant or animal species present.

- Location and density of volunteer plant growth.

Appendix A, Criterion 12 of 10 CFR Part 40 requires the DOE to submit results of all routine site inspections to the NRC and state of Colorado within 90 days of the last site inspection for each calendar year. A copy of all site inspection reports will be maintained in the Durango permanent site file and a copy of the inspection report will also be sent to the state of Colorado. 



\subsection{UNSCHEDULED INSPECTIONS}

An unscheduled inspection may be triggered by reports or information indicating that site integrity has been or may be compromised.

\section{$7.1 \quad$ FOLLOW-UP INSPECTIONS}

Follow-up inspections investigate and quantify specific problems found during a scheduled inspection, ground water sampling event, special study, or other DOE activity. They determine whether processes currently active on or near the site threaten site security or stability, and they evaluate the need for custodial maintenance and/or repair or corrective action.

Follow-up inspections should be made by technical specialists in an appropriate discipline (e.g., a soils scientist or geomorphologist to evaluate erosion processes).

The follow-up inspection begins with an on-site visit to determine the need for definitive tests or studies. Additional visits may be scheduled if more data are needed to draw conclusions and recommend corrective action. If custodial maintenance or repair or corrective action is warranted, the DOE will notify the NRC, the state of Colorado, and the adjacent residents (see Section 9.0).

\subsection{CONTINGENCY INSPECTIONS}

Contingency inspections are unscheduled inspections ordered by the DOE when it receives outside information indicating that site integrity has been or may be threatened. Events that could trigger contingency inspections include severe vandalism, intrusion by humans or livestock, severe rainstorms, or events such as tornadoes or earthquakes.

The GJPO must submit an assessment of each unusual event to the NRC within 60 days of the initial report that damage or disruption has occurred at the Bodo Canyon disposal site (10 CFR Part 40). The state of Colorado will receive a copy of this report from GJPO. At a minimum, this report must include the following:

- A description of the problem.

- A description of how the inspection was conducted.

- A preliminary assessment of the maintenance or repair or corrective action required.

- Conclusions and recommendations.

- Assessment data, including field and inspection data, and photographs. 
- Names and qualifications of the field inspectors.

A copy of the report and all other data and documentation will be maintained in the Durango permanent site file. The annual report to the NRC will include the results of these contingency inspection reports. If appropriate, the annual (or scheduled) Bodo Canyon disposal site inspection report will also contain the results of these inspections.

After reviewing the preliminary inspection/assessment report, the DOE must submit a corrective action plan for NRC approval within the 60-day period required by 10 CFR Part 40 . Based on the findings in these reports, the GJPO will complete corrective action, following the guidance for implementing corrective action described in Section 9.0. 


\subsection{CUSTODIAL MAINTENANCE}

Custodial maintenance will be performed as needed at the Bodo Canyon disposal site. Annual site inspections, follow-up inspections, and contingency inspections will determine the need for maintenance or repairs.

\subsection{PLANNED MAINTENANCE}

Planned maintenance will prevent the growth and establishment of shrubs and trees (principally into the cell) and will prevent erosion. The frequency of the maintenance will be determined after site visits provide adequate information on amount and type of growth.

\subsection{UNSCHEDULED MAINTENANCE OR REPAIR}

Unscheduled custodial maintenance that may be required at the Bodo Canyon disposal site may include the following:

- Repair or replace gates, entrance signs, perimeter warning signs, and other site features, if necessary.

- Confirm survey monument locations.

- Maintain access road.

- Monitor security of settlement plates and possibly install a lock on each casing.

- Repair cover.

- Reestablish survey control and boundary monuments.

- Remove tumbleweeds or other debris from the diversion channels.

- Repair disposal cell due to animal burrows.

- Repair holding pond drain pipe.

- Reseed, as appropriate.

- Remove volunteer plant growth on the disposal cell or in the diversion channels.

The GJPO will prepare a statement of work (SOW) and purchase order to authorize these kinds of repairs. This SOW will include contractor qualifications. 
If problems are identified that may affect the integrity of the disposal cell or compliance with the EPA standards, the NRC must approve the recommended action in advance. The action will be treated as a corrective action.

\subsection{CERTIFICATION AND REPORTING REQUIREMENTS}

The contractors' annual report to the NRC must include the following information on unscheduled maintenance or repair:

- Summary of work required.

- Work order, purchase order, or SOW.

- Contractor qualifications, if applicable.

- Contractor documentation of work completion.

- DOE certification of work completion.

The DOE will inspect the site, as necessary, and review the report before certifying that all work is completed in accordance with all required specifications. Copies of all records, documentation, and certifications will be included in the Durango permanent site file. Copies of all relevant documentation will be transmitted to the state of Colorado by DOE. 


\subsection{CORRECTIVE ACTION}

If the stability of the disposal cell is threatened, corrective action could include temporary emergency measures. To minimize or avoid their recurrence, the DOE also would evaluate the factors that caused the problem.

The following conditions could require corrective action:

- Surface rupture of the disposal cell (could indicate differential settlement or severe shrinkage of the cover materials).

- Subsidence, sliding, or slope instability on the disposal cell (caused by mass wasting, liquefaction, differential settlement, or other events).

- Development of rills or gullies on the disposal cell.

- Deterioration of the erosion protection rock on the disposal cell or in the drainage ditches.

- Seepage originating from the disposal cell or the toe of cell.

- Gully development on or immediately adjacent to disposal site property that could affect the integrity of the disposal cell.

- Rapid headward cutting of a gully, arroyo, or ravine that threatens the stability of the disposal cell.

- Damage to the cell cover or disposal site property from extreme seismic events, other catastrophic events, or vandalism (e.g., removal of cell construction materials).

- Verification of an excursion during the ground water monitoring program.

When a potential problem is identified, the DOE will notify the NRC and the state of Colorado and will submit an inspection/preliminary assessment report for NRC review no more than 60 days after the problem is identified. The preliminary assessment report will evaluate the problem and will recommend the next step (e.g., immediate action or continued evaluation). After the NRC reviews the report and recommendations, the DOE will develop a corrective action plan for NRC approval. The DOE may combine the inspection and recommendation in one report, depending on the severity of the problem. When the NRC approves the corrective action, the DOE will implement the plan. Figure 9.1 identifies the key elements in the corrective action process.

NRC regulations do not stipulate a time frame for implementing corrective action. However, EPA standards (40 CFR \$192.04(c)) require that a corrective action program begin within 18 months after an exceedance in established ground water concentration limits is found. Assessing the extent of the problem and developing a corrective action 


\section{NEED FOR CORRECTIVE ACTION IDENTIFIED}

- DOCUMENT AND REPORT PROBLEM TO NRC, STATE

- eVAluATE PROBLEM AND PROPOSE A solution

- DEVELOP CORRECTIVE ACTION PLAN AND NOTIFY NRC AND STATE

- SELECT CONTRACTOR TO PERFORM CORRECTIVE ACTION

- ESTABLISH CONTRACTUAL CONDITIONS FOR PERFORMING CORRECTIVE ACTION AND GUARANTEE CORRECTIVE ACTION WILL BE PERFORMED IN ACCORDANCE WITH CONTRACTUAL AGREEMENTS AND DESIGN SPECIFICATIONS

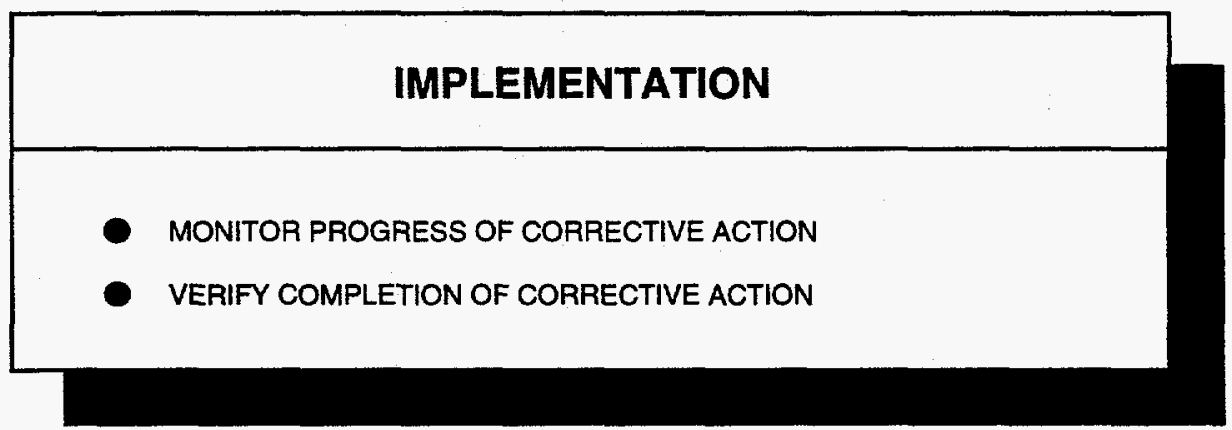

\section{CERTIFICATION}

FIGURE 9.1

KEY ELEMENTS IN THE CORRECTIVE ACTION PROCESS 
plan will not be considered initiation of the corrective action program. Section 9.0 of the LTSP guidance document contains further details on corrective action (DOE, 1992a).

After corrective action is complete, all work completed will be certified in accordance with EPA standards. The NRC will review this certification. A copy of the certification statement will become part of the Durango permanent site file, as will all reports, data, and documentation generated during the corrective action. 


\subsection{RECORD KEEPING AND REPORTING REQUIREMENTS}

The GJPO will maintain a Durango permanent site file containing all the information needed to prepare for and conduct site surveillance. All original deeds, custody agreements, and other property documents will be kept at the DOE Project Team Office, Albuquerque, New Mexico. Copies of these documents also will be maintained in GJPO files. Reports of sitesurveillance activities will be maintained in accordance with archival procedures set forth in 41 CFR Part 101, 36 CFR Parts 1220-1238 (Subchapter B, Records Management), and DOE Order 1324.2A, Record Disposition.

As required by 10 CFR Part 40 , the GJPO will provide an annual report to the NRC and to the state of Colorado documenting the results of the long-term surveillance program and will be added to the Durango permanent site file. The annual reports and supporting documentation in the permanent site file will accomplish the following:

- Document disposal site performance.

- Demonstrate that licensing provisions were met.

- Provide information needed to forecast future site surveillance and monitoring needs.

- Inform the public that site integrity has been maintained.

The results of the ground water monitoring program will be reported once every 5 years to the NRC and the state of Colorado. The UMTRA Project Team will be responsible for preparing these ground water monitoring reports until this responsibility is transferred to the GJPO. 


\subsection{EMERGENCY NOTIFICATION AND REPORTING}

The Bodo Canyon disposal cell was designed to comply with EPA standards (40 CFR Part 192), with minimum maintenance and oversight for a period of 1000 years, or at least 200 years. However, the DOE has requested notification from state, federal, and local agencies of discoveries or reports of any intrusion or damage at the disposal site as well as the occurrence of earthquakes, tornadoes, or floods in the disposal site area to ensure the disposal cell remains in compliance with EPA standards.

The DOE is negotiating notification agreements with the U.S. Geological Survey (USGS) National Earthquake Information Center (Denver, Colorado), the Colorado office of the National Weather Service (NWS), and the La Plata County Sheriff's Department. Copies of these agreements are presented in Attachment 7. The designated point of contact for emergency notification is the GJPO 24-hour telephone line, 970-248-6070. This number is posted on the Bodo Canyon disposal site entrance sign so the public can notify the DOE if problems are discovered.

The DOE has requested that the La Plata County sheriff and the district ranger of the San Juan National Forest, Durango, Colorado, notify the GJPO of any unusual occurrences in the disposal site area that may affect surface or subsurface stability.

The USGS National Earthquake Information Center has agreed to notify the GJPO if a seismic event occurs that fits any of the following descriptions (Attachment 7):

- Any earthquake of magnitude 3.0 or greater, within 0.3 degree (about $20 \mathrm{mi}$ [30 km] at N37.15 latitude and W107.90 longitude) of the site.

- Any earthquake of magnitude 5.0 or greater, within 1.0 degree (about $70 \mathrm{mi}$ [110 km] at N37.15 latitude and W107.90 longitude) of the site.

The DOE will complete an agreement with the Colorado office of the NWS in Denver, Colorado, to notify the GJPO within 8 hours of issuing a flash flood or tornado warning in La Plata County, Colorado. When this agreement is final, the agreement letter will be place in Attachment 7. 


\subsection{QUALITY ASSURANCE}

The GJPO is responsible for developing QA procedures specific to the UMTRA Project longterm surveillance program. The GJPO Long-Term Surveillance and Maintenance Program Quality Assurance Program Plan specifies the following requirements (DOE, 1992b):

- Program planning.

- Program inspections, site maintenance, corrective action, and emergency responses.

- Monitoring, if required.

- Qualified, trained personnel.

- Program surveillance and audits.

- Analytical QA.

- Analytical data validation.

All site inspections, monitoring data, records, photographs, maps, and other information related to the LTSP for the Bodo Canyon disposal site are subject to formal and unannounced audits by the DOE or the NRC. Specific QA criteria have been developed for aerial photographs (DOE, 1992b).

\section{Ground water monitoring}

Ground water monitoring is required for compliance with 40 CFR Part 192 at the disposal site. The ground water monitoring program will be conducted by the UMTRA Project Team until the site is licensed. Thereafter, site monitoring under the LTSP will be conducted by the GJPO.

QA activities will:

- Identify the organizations involved with ground water monitoring activities and describe their operational, field, laboratory, and QA responsibilities.

- Summarize the data quality objectives $(D Q O)$ for ground water restoration and the $Q A$ objectives for measuring data: precision, accuracy, representativeness, completeness, and comparability.

- Discuss procedures for field and laboratory analysis of environmental samples and for sample custody, handling, packaging, shipping, and documentation. Laboratory analyses of environmental samples include inorganic, organic, and radiometric constituents; and other chemical, physical, and water-quality parameters. 
- Discuss QA in field measurements. The QA procedures for field and laboratory methods appear in applicable SOPs in the UMTRA Technical Assistance Contractor SOP manual (JEG, n.d.). When an SOP has not been completed for an activity, best management practices (standard industry procedures) will be followed.

- Describe data validation, $\mathrm{QA} / \mathrm{OC}$, data reporting calibration frequency, and preventive maintenance procedures for field and laboratory equipment.

- Establish guidance on internal QC checks, data reduction, validation, and reporting requirements for field and laboratory environmental samples.

- Present UMTRA Project system audit procedures and technical, field, and laboratory performance audit procedures.

- Suggest field and laboratory corrective actions and procedures for corrective actions resulting from audits.

- Present QA reporting procedures, outlining reporting requirements to management.

- Describe record keeping. 


\subsection{PERSONNEL HEALTH AND SAFETY}

DOE Order 5480.1B, Environment, Safety and Health Program for DOE Operations, establishes personnel health and safety procedures for all DOE operations. After a disposal site is licensed and transferred to the GJPO, the GJPO is responsible for health and safety procedures for GJPO personnel. The GJPO will determine health and safety requirements for its personnel and subcontractors in accordance with applicable orders and federal regulations.

The inspector's health and safety training and certifications; the locations and telephone numbers for emergency medical and law enforcement facilities; and the facility contact 24-hour telephone number will be verified before each site inspection.

Specific safety concerns at the Bodo Canyon disposal site include slip, trip, and fall hazards; animal, snake, and insect bites; heat and cold stress; fire hazards; puncture and cut hazards; and road hazards. Safety equipment should be taken to the site to reduce exposures to identified hazards and to provide first aid to anyone at the site who may need it.

\subsection{EMERGENCY MEDICAL AND LAW ENFORCEMENT}

Local emergency medical and law enforcement agencies were briefed on the scope of work at the disposal site during the long-term surveillance and maintenance phase. The following 24-hour emergency numbers are pertinent:

- Fire: 911

- Ambulance: 911 or $970-247-4311$

- Police/sheriff: 911 or $970-385-2910 ; 970-247-1157$

La Plata County has two hospitals, Mercy Medical Center and La Plata Community, both of which are in Durango. The nearest hospital with ambulance service, a 24-hour emergency room, trauma service, and standard clinical facilities is Mercy Medical Center, approximately $5 \mathrm{mi}(8 \mathrm{~km})$ northeast of the Bodo Canyon disposal site (DOE, 1985). Mercy Medical center also has a "life flight" capability for transporting patients to Durango. Directions to the hospital from the site are as follows:

Take CR 211 to U.S. Highway 160, turn left on U.S. Highway 160 and continue to Park Avenue; turn right on Park Avenue. Mercy Medical Center Hospital is at 375 East Park Avenue.

\section{Location of nearest telephone}

The telephone closest to the disposal site is approximately $0.75 \mathrm{mi}(1.2 \mathrm{~km})$ to the southwest where the Colorado Division of Wildlife (CDOW) leases or rents a house. The CDOW maintains a shop at this residence and workers are present daily throughout the spring, summer, and fall work seasons. The other nearest 
residents are in Durango and Wildcat Canyon, northeast and northwest of the site respectively. Because a telephone may not be accessible, a mobile phone must be taken on site visits (DOE, 1985).

\subsection{REPORTABLE INCIDENTS}

The inspection team should be briefed by the GJPO health and safety officer on potential site hazards and other requirements before site inspections or visits. The GJPO health and safety manager's number is 970-246-6730.

In accordance with DOE Order 5000.3B, any accident, injury, or environmental event (e.g., tornado or flood) occurring during the site inspection is a reportable incident. The condition or event must be reported to the GJPO facility manager or designated contact within 8 hours of the occurrence. The GJPO facility manager's 24-hour telephone number for reporting an incident is 970-248-6070. 


\subsection{LIST OF CONTRIBUTORS}

The following individuals contributed to the preparation of this LTSP.

\begin{tabular}{ll}
\hline Name & Contribution \\
\hline C. Saumur & Document coordinator \\
D. Tarbox, R. Heydenburg & Hydrogeology \\
G. Hartmann, R. Meyers & Engineering \\
P. Martinez & Real estate \\
R. Neri Zagal, J. Lommler, A. Holm. S. Cox & Document review \\
S. Cox, E. Artiglia & Site management, document review \\
C. Yancey & Peer review \\
J. Lommler & Engineering review \\
L. Keith, C. Slosberg & Text processing \\
L. Wagner & Graphic design \\
D. Tamez, A. Cree, D. Thalley & Technical editing, document production, \\
\end{tabular}




\subsection{REFERENCES}

CGS (Colorado Geological Survey), 1981. Preliminary Report on Potential Sites Suitable for Relocation and/or Reprocessing of the Durango Uranium Mill Tailings Pile, Open-File Report 81-1, prepared by the Colorado Geological Survey, Denver, Colorado, with assistance from Robert M. Kirkham and the Four Corners Environmental Research Institute.

DOE (U.S. Department of Energy), 1993a. Licensing Plan for UMTRA Project Disposal Sites, final, September 1993. DOE/AL/62350-9F, prepared by the U.S. Department of Energy, UMTRA Project Office, Albuquerque Operations Office, Albuquerque, New Mexico.

DOE (U.S. Department of Energy), 1993b. 1992 Annual Prelicensing Inspection of the Durango, Colorado, UMTRA Project Disposal Site, DOE/ID/12584-141, prepared by the U.S. Department of Energy, UMTRA Project Office, Albuquerque Operations Office, Albuquerque, New Mexico.

DOE (U.S. Department of Energy), 1992a. Guidance for Implementing the UMTRA Project Long-Term Surveillance Program, final, UMTRA-DOE/AL-350125.0000, prepared by the U.S. Department of Energy, UMTRA Project Office, Albuquerque Operations Office, Albuquerque, New Mexico.

DOE (U.S. Department of Energy), 1992b. Long-Term Surveillance and Maintenance Program Quality Assurance Program Plan, P-GJPO-152, July 1992, prepared for the U.S. Department of Energy by Chem Nuclear Geotech, Inc., DOE Grand Junction Projects Office, Grand Junction, Colorado.

DOE (U.S. Department of Energy), 1991. Remedial Action Plan and Site Design for Stabilization of the Inactive Uranium Mill Tailings Site at Durango, Colorado, UMTRA-DOE/AL-050503.0000, prepared by the U.S. Department of Energy, UMTRA Project Office, Albuquerque Operations Office, Albuquerque, New Mexico.

DOE (U.S. Department of Energy), 1985. Final Environmental Impact Statement: Remedial Actions at the Former Vanadium Corporation of America Uranium Mill Site, Durango, La Plata County, Colorado, DOE/EIS-0111F, prepared by the U.S. Department of Energy, UMTRA Project Office, Albuquerque Operations Office, Albuquerque, New Mexico.

DOE (U.S. Department of Energy), 1981. Cooperative Agreement Between the United States Department of Energy and the State of Colorado, DOE Cooperative Agreement Number DE-FC04-81AL16257, prepared by the U.S. Department of Energy, UMTRA Project Office, Albuquerque Operations Office, Albuquerque, New Mexico. 
EPA (U.S. Environmental Protection Agency), 1992. Addendum to Interim Final Guidance Statistical Analysis of Ground-Water Monitoring Data at RCRA Facilities, Office of Solid Waste Management Division, U.S. Environmental Protection Agency, Washington, D.C.

EPA (U.S. Environmental Protection Agency), 1988. Guidance on Remedial Actions for Contaminated Ground Water at Superfund Sites, 540/G-88/003, OSWER Directive 9283.1-2, Office of Solid Waste and Emergency Response, Washington, D.C.

EPA (U.S. Environmental Protection Agency), 1986. RCRA Groundwater Monitoring Technical Enforcement Guidance Document, OSWER Directive 9950.1, Office of Solid Waste and Emergency Response, Division of Waste Management, Washington, D.C.

JEG (Jacobs Engineering Group Inc.), n.d. Albuquerque Operations Manual, standard operating procedures, prepared by Jacobs Engineering Group Inc., for the U.S. Department of Energy, Environmental Restoration Division, UMTRA Project Team, Albuquerque, New Mexico.

Lehmann, E. L., 1975. Nonparametrics - Statistical Methods Based on Ranks, prepared by the University of California Berkeley, with special assistance from H. J. M. D'Abrera of the University of California Berkeley, Holden-Day, Inc., San Francisco, California.

MK-F (Morrison Knudsen-Ferguson), 1991. "Durango Draft Completion Report," Contract No. DE-AC04-83AL18796, prepared by Morrison Knudsen-Ferguson for the U.S. Department of Energy, UMTRA Project Office, Albuquerque Operations Office, Albuquerque, New Mexico.

MK-F (Morrison Knudsen-Ferguson Company), 1990. Surveillance and Maintenance Subcontract Documents, Durango, Colorado, November 1990, prepared by Morrison Knudsen-Ferguson for the U.S. Department of Energy, UMTRA Project Office, Albuquerque Operations Office, Albuquerque, New Mexico.

\section{CODE OF FEDERAL REGULATIONS}

10 CFR Part 40, Domestic Licensing of Source Material, U.S. Nuclear Regulatory Commission.

36 CFR Parts 1220-1238, National Archives and Records, "Subchapter B, Records Management," National Archives and Records Administration.

40 CFR Part 192, Health and Environmental Protection Standards for Uranium and Thorium Mill Tailings, U.S. Environmental Protection Agency. 
41 CFR Part 101, Federal Property Management Regulations, General Services Administration.

\section{DOE ORDERS}

Order 1324.2A, Records Disposition, September 13, 1988, Office of Information Resource Management, U.S. Department of Energy, Washington, D.C.

Order 5000.3B, Occurrence Reporting and Processing of Operations Information, February 22, 1993, U.S. Department of Energy, Washington, D.C.

Order 5400.1, General Environmental Protection Program, June 29, 1990, U.S. Department of Energy, Environmental Protection Division, Office of Environment, Safety and Health, Washington, D.C.

Order 5480.1B, Environment, Safety and Health (ES\&H) Program for DOE Operations, September 1986, U.S. Department of Energy, Safety Programs Division, Washington, D.C.

Order 5700.6C, Quality Assurance, U.S. Department of Energy, August 21, 1991, U.S. Department of Energy, Office of Nuclear Energy, and Office of Environment, Safety, and Health, Washington, D.C.

\section{FEDERAL REGISTER}

60 FR 2854, Groundwater Standards for Remedial Actions at Inactive Uranium Processing Sites, final rule, 11 January 1995.

\section{UNITED STATE CODE}

42 USC $\$ 7901$ et seq., Uranium Mill Tailings Radiation Control Act, 8 November 1978.

42 USC $\$ 7914$ et seq., Acquisition and Disposition of Lands and Materials, 8 November 1978. 
ATTACHMENT 1

NRC CONCURRENCE AND LICENSING DOCUMENTATION

(DOCUMENTATION TO BE PROVIDED UPON NRC LICENSING) 


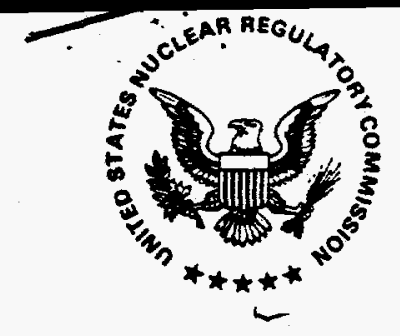

NRC/UMT/1194/0054

UNITED STATES

NUCLEAR REGULATORY COMMISSION

WASHINGTON, D.C. 20555-0001

November 4, 1994

Charles Cormier, Acting Project Manager

Uranium Mill Tailings Remedial

Action Project Office

U.S. Department of Energy

Albuquerque Operations Office

P.O. Box 5400

Albuquerque, NM 87115

SUBTECT: DURANGO REMEDIAL ACTION PLAN SIGNATURE PAGE

Dear Mr. Cormier:

This letter is in response to the U.S. Department of Energy (DOE) letter dated, September 30, 1994, requesting that the U.S. Nuclear Regulatory Commission sign and return the Remedial Action Plan (RAP) signature page for the Durango, Colorado, Uranium Mill Tailings Remedial Action site. The Durango RAP signature page signed by Ramon Hall of the NRC Uranium Recovery Field Office, which was returned to DOE by letter dated July 19,1994 (copy enclosed), was evidently mislaid by DOE. These new signature pages will supersede the previous pages signed by Ray Hall.

Two signed original copies of the signature page are enclosed. If you have any questions regarding this letter or the enclosure, please contact Ken Hooks at (301) 415-7777.

Sincerely,

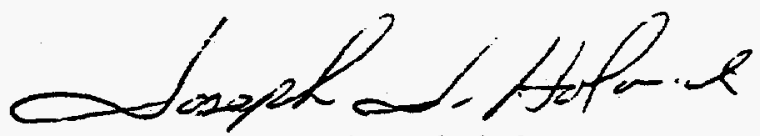

Joseph J. Holonich, Chief

High-Level Waste and Uranium

Recovery Projects Branch

Division of Waste Management

Office of Nuclear Material Safety

and Safeguards

Docket No. WM-48

Enclosure: As stated

cc: C. Smythe, DOE Albq.

D. Bierley, TAC Albq.

M. Abrams, DOE, Albq. 
U.S. Department of Energy Agreement No. DE-FC04-81AL16257 Appendix B, Remedial Action Plan for Grand Junction, Colorado

The United States of America

Department Of Energy

\section{State Of Colorado}

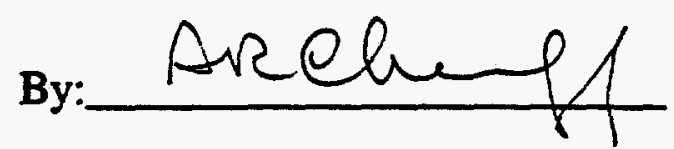

Albert R. Chernoff

Project Manager

Uranium Mill Tailings Remedial Action Project Office

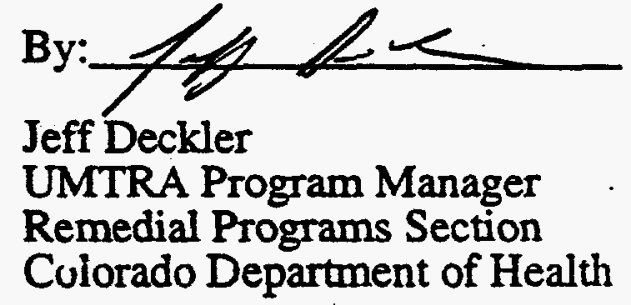

Date:

CONCURRENCE:

NUCLEAR REGULATORY COMMISSION

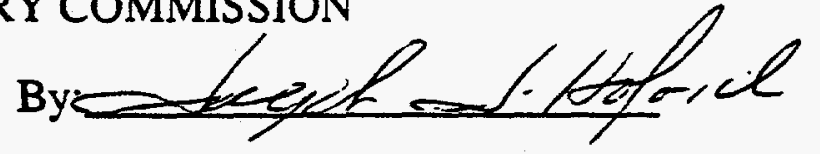

Joseph J. Holonich Acting Chief

Hight Level waste and Uranium Recovery Brajects

Division of Eowel Waste

Management Doeminimis

Office of Nuclear Materials

Safety and Safeguards

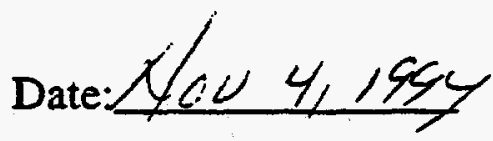


ATTACHMENT 2

SITE OWNERSHIP/CUSTODY DOCUMENTATION 


\section{REAL ESTATE DOCUMENTATION \\ LONG-TERM SURVEILLANCE PLAN \\ BODO CANYON DISPOSAL SITE \\ DURANGO, COLORADO}

\section{GENERAL}

State acquisition of the Bodo Canyon disposal site was completed by the Remedial Program Management Unit of the Colorado Department of Public Health and Environment. The Bodo Canyon disposal site acquired by the state contains approximately 120.6 acres (ac) (48.8 hectares [ha]). The site was acquired in two tracts. The first tract, Tract 101, was acquired from the Colorado Department of Natural Resources, Division of Wildlife, through a quit claim deed dated 4 August 1987. This tract consisted of 38.7 ac (15.7 ha). The second tract, Tract 102, was acquired from the state land board and consisted of 81.36 ac (32.93 ha). The acquisition was effected through a real estate exchange agreement dated 15 May 1990.

The U.S. Department of Energy (DOE) has requested that the state of Colorado forward final deeds and supporting documentation for the transfer of the Bodo Canyon uranium mill tailings disposal site to the federal government pursuant to 42 USC $\$ 7914(f)$ of the Uranium Mill Tailings Radiation Control Act of 1978.

On 20 October 1993, the state of Colorado forwarded the documentation to the U.S. Army Corps of Engineers (USACE) for review. The USACE has since determined that the documentation is complete and that no encumbrances are on the deeds. The USACE is waiting for a letter from the DOE before completing the title transfer. The letter will be based on NRC concurrence with DOE certification that the site meets the EPA cleanup standards.

\section{LEGAL DESCRIPTIONS}

\section{Disposal site/boundaries}

(a) Tract 101

A Tract of land in the East One-half (E 1/2) of Section Thirty-six, (Sec. 36), La Plata County, state of Colorado, being more particularly described as follows:

Beginning at a point on the east line of said Sec. 36 of the New Mexico Principal Meridian, which point bears South $00^{\circ} 39^{\prime} 08^{\prime \prime}$ East a distance of 130.00 feet from the Northwest corner of Section Thirty-one (Sec. 31), Township Thirty-four and One-half North (T34 1/2 N), Range Nine West (R9W);

Thence West a distance of $\mathbf{2 0 7 5 . 0 0}$ feet to a point; 
Thence South a distance of 1700.00 feet to a point:

Thence East a distance of 2094.35 feet to the east line of said Sec. 36;

Thence North $00^{\circ} 39^{\prime} 08^{\prime \prime}$ West a distance of 1700.00 feet to the point of beginning; said tract contains 81.36 acres (32.93 ha), more or less.

(b) Tract 102

A Tract of land in Section Thirty-one (Sec. 31), Township Thirty-four and one half North (T34 1/2 N), Range Nine West (R9W), of the NMPM in La Plata County, state of Colorado being more particularly described as follows:

Beginning at a point on the West line of said Section 31, whence the Northwest corner of said Section 31 bears North $00^{\circ} 39^{\prime} 08^{\prime \prime}$ West a distance of 130.00 feet;

Thence East a distance of 1,000.00 feet;

Thence South a distance of $1,700.00$ feet;

Thence West a distance of 980.65 feet to the West line of said Section 31; Thence North $00^{\circ} 39^{\prime} 08^{\prime \prime}$ West a distance of $1,700.11$ feet to the point of beginning; said Tract contains 38.7 acres (15.70 ha) more or less.

Also: Including all rights presently owned by the Grantor to any and all minerals, ore and metals of any kind and character and all coal, asphaltum, oil, gas, geothermal resources or other substances in, on or under the above described tract being conveyed.

(2) Filed: Deed recordation data will be provided once transfer has been completed.

Deeds not yet recorded.

\section{REPOSITORY}

Real estate correspondence and related documents are maintained and filed by the Property Management Branch, Property and Administrative Services Division, Albuquerque Operations Office, under the supervision of Corville J. Nohava, (505) 845-6450.

\section{REFERENCE}

42 USC $\$ 7901$ et seq., Uranium Mill Tailings Radiation Control Act, 8 November 1978. 
ATTACHMENT 3

BODO CANYON TOE DRAIN CLOSURE AND HOLDING POND DECOMMISSIONING PLAN 


\section{TABLE OF CONTENTS}

Section

Page

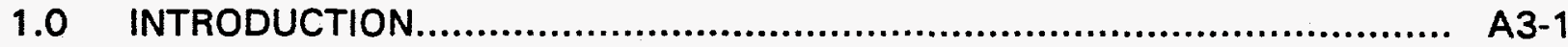

2.0 CONTAMINANT CHARACTERIZATION....................................... A3-9

2.1 Sludge disposal alternatives .............................................. A3-10

2.1.1 UMTRA Project disposal cell ....................................... A3-10

2.1.2 Title II sites.............................................................. A3-10

2.1.3 Commercial radioactive waste disposal facility .................. A3-11

2.1.4 Regional compact repository........................................A3-11

2.1.5 DOE low-level waste disposal site ................................ A3-11

2.1.6 40 CFR Part 192 remediation .................................... A3-11

2.2 Preparing sludge for shipment ............................................ A3-12

2.3 Transporting sludge and contaminated materials .......................... A3-12

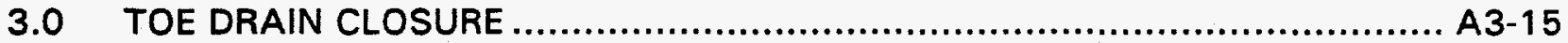

3.1 Site restoration................................................................ A3

3.2 NRC approval ............................................................... A3 15

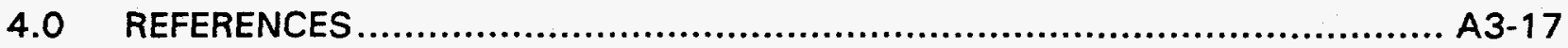




\section{LIST OF FIGURES}

\section{Section}

Page

A3.1 Toe drain and holding pond, Bodo Canyon, Colorado, disposal site

A3.2 Profile of discharge trench and holding pond, Bodo Canyon,

Colorado, site

A3.3 Typical section of drainage trench, Bodo Canyon, Colorado, site

A3.4 Holding pond - site restoration, Bodo Canyon, Colorado, site

A3.5 Toe drain closure and holding pond decommissioning flow chart,

Bodo Canyon, Colorado, site 


\section{LIST OF ACRONYMS AND ABBREVIATIONS}

\section{Acronym}

CERCLA

DOE

DOT

EPA

$M C L$

NRC

PVC

RCRA

RRM

VP

\section{Definition}

Comprehensive Environmental Response, Compensation, and Liability Act

U.S. Department of Energy

U.S. Department of Transportation

U.S. Environmental Protection Agency

maximum concentration limit

U.S. Nuclear Regulatory Commission

polyvinyl chloride

Resource Conservation and Recovery Act

residual radioactive material

vicinity property 


\subsection{INTRODUCTION}

Excess pore water from the tailings material has been collected in a toe drain collection system along the eastern slope of the Bodo Canyon disposal cell (disposal site) and has been draining into a 320,000-gallon (gal) $11,200,000-$ liter [L]) lined holding pond since November 1989 (Figures A3.1 through A3.4). To proceed with licensing the disposal site, the holding pond closure plan must be documented so that when the administrative decision is made to permanently shut off the toe drain, the decommissioning plan may be followed to allow for removing of the contaminated sludge, liner, and contaminated soil to a suitable repository. The decision will be based upon the observation that sufficient water has been drained from the cell to preclude the possibility that the seeps could reappear or produce unacceptable hydrostatic pressures on the slope of the cell. Once this has been established, the toe drain system will be discontinued. A flow chart of the toe drain closure and holding pond decommissioning plan is shown in Figure A3.5. All regulatory and permitting requirements in effect at the time the closure plan is initiated will be applied to the removal of contaminated materials and closure of the site. After the contaminated materials are removed, the toe drain will be permanently sealed, the site will be regraded, and suitable erosion protection measures will be incorporated into the existing design features of the disposal cell.

\section{BACKGROUND}

The toe drain and holding pond were installed after extensive seepage appeared on the eastern slope of the disposal cell during construction in the fall of 1988 . The toe drain enabled cell closure to proceed by allowing correct placement of the clay cover on unsaturated tailings in the area where the seep appeared. This procedure also prevented hydrostatic pressure from developing against the inside surface of the sideslope. Other alternatives for dewatering the cell were considered, such as deep wells, an ejector system, and horizontal drains. The toe drain was selected because it allowed the disposal cell construction to proceed with minimal effect on the original completion schedule.

Because the seep initially appeared just above the top of the low-permeability liner (at an elevation of 7052 feet (ft) (2149 meters [m]), just above the top of the clean fill dike, the tailings were thought to be saturated from the base of the cell to the top of the clean fill dike. The source of the water likely resulted from the significant volumes of water used for dust control $(80,000 \mathrm{gal}[300,000 \mathrm{~L}]$ per day) and the water added for compaction requirements. A phreatic surface was recorded in monitor wells that were installed in the tailings material. Assuming full saturation to the base of the cell, 15 million gal ( 57 million L) of drainable water were estimated to reside in the cell. However, when test pits were excavated to construct the toe drain, ponded water was observed on a vicinity property (VP) material low-permeability layer. Extensive areas below the VP layer were not saturated. The perched zone of saturation above the VP layer also was indicated by the flow rates recorded from the dewatering wells, which were installed to construct the trench and to dewater the cell as much as possible. The flow rates were directly proportional to a saturated thickness corresponding to the thickness between the top of the VP layer and the measured phreatic surface. Additional lab testing of soil samples 


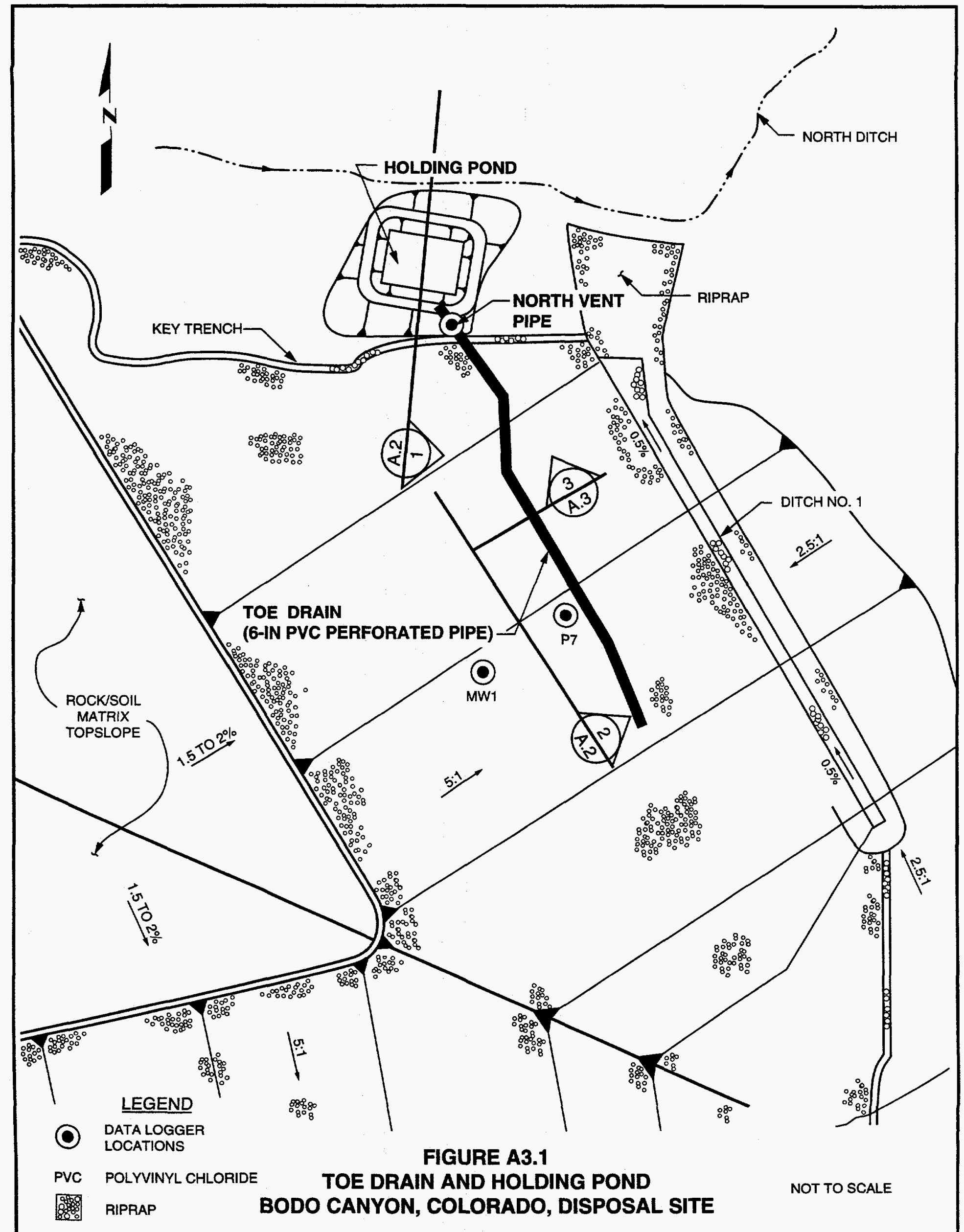



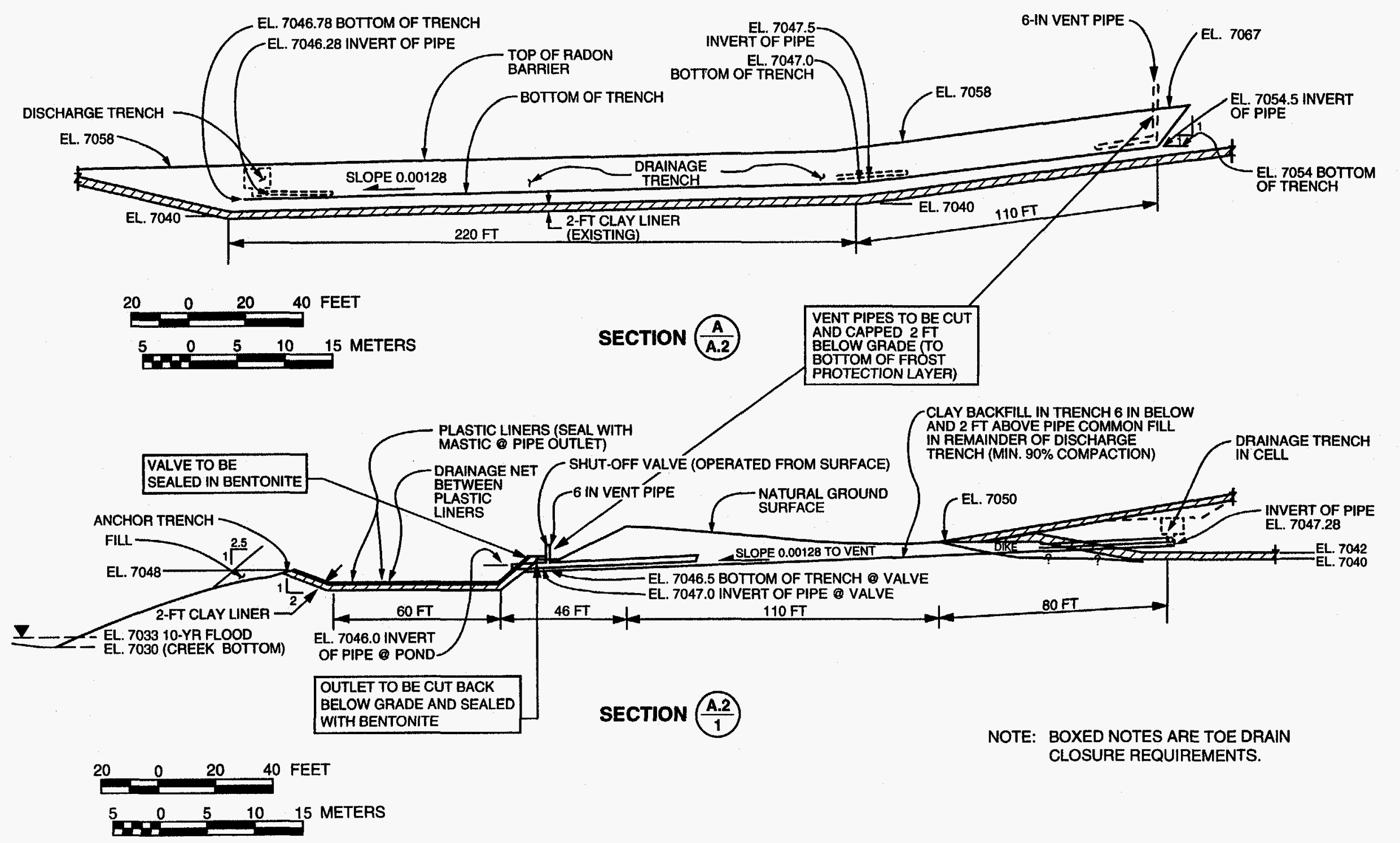

NOTE: BOXED NOTES ARE TOE DRAIN CLOSURE REQUIREMENTS.

FIGURE A3.2

CROSS SECTION OF DISCHARGE TRENCH AND HOLDING POND BODO CANYON, COLORADO, SITE 


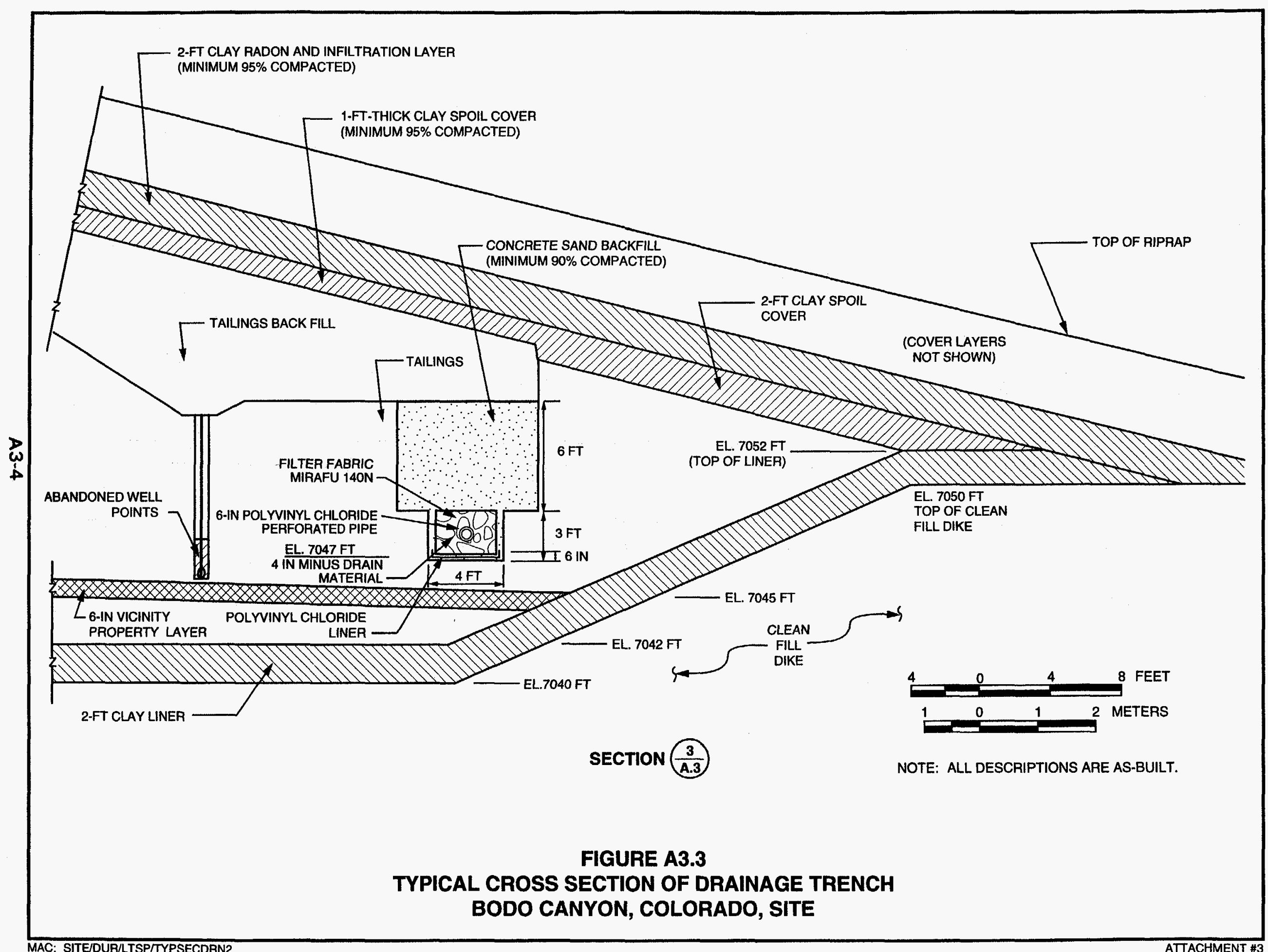




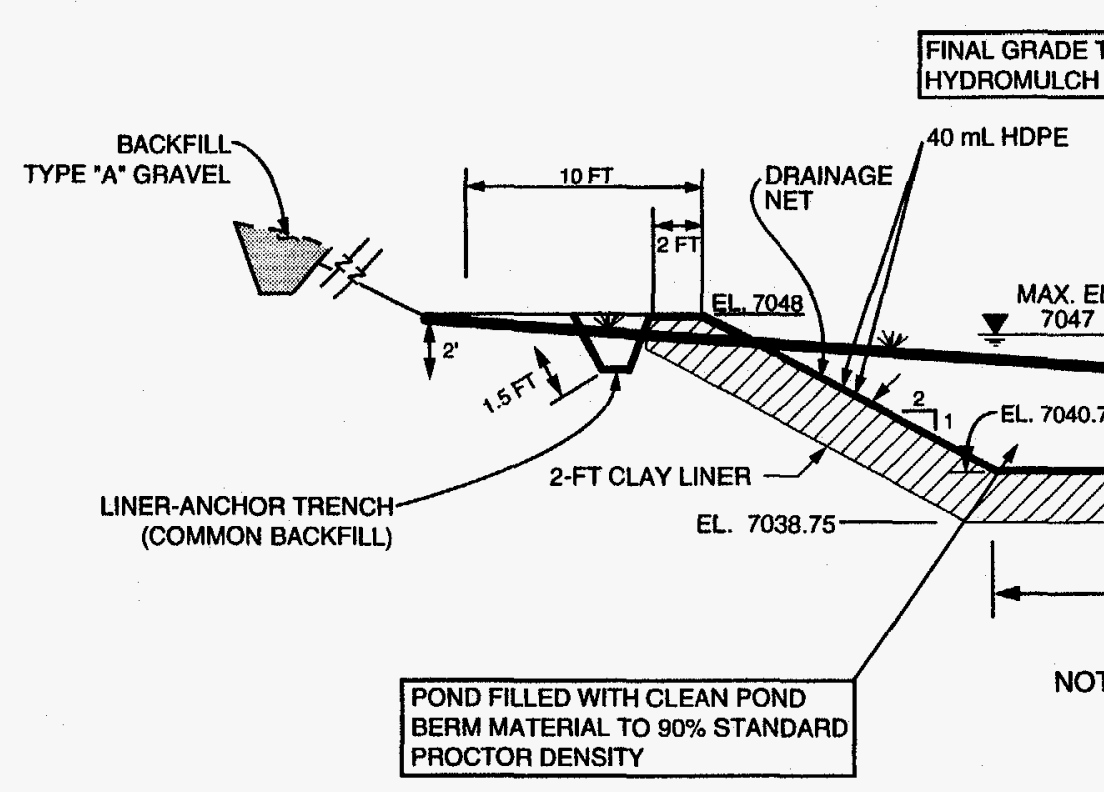

FINAL GRADE AFTER REMOVAL

OF SLUDGE, LINER, AND

CONTAMINATED SOIL. SITE

GRADED TOPROVIDE SHEET

FLOW TO ADJACENT ARROYO

PROCTOR DENSITY

NOTE: BOXED NOTES ARE HOLDING POND

DECOMMISSIONING PLAN REQUIREMENTS.

EL. 7040.5

EL. 7038.5

LINER-ANCHOR TRENCH (COMMON BACKFILL)

NOT TO SCALE

\section{LEGEND \\ $\mathrm{mL}$ MILLILITER \\ $\$$ WATER LeVEL}

HDPE HIGH-DENSITY POLYETHYLENE 


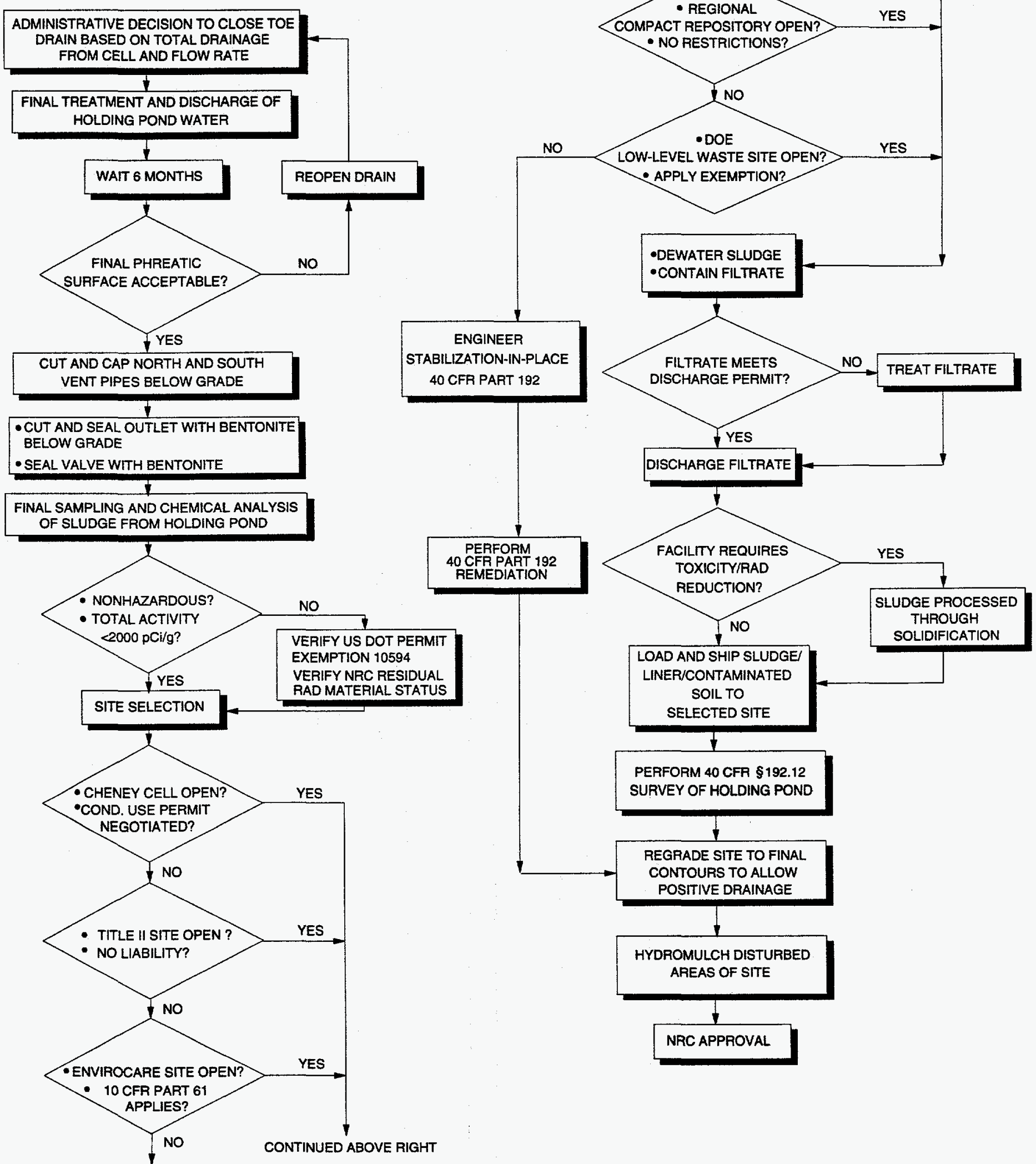

CONTINUED ABOVE RIGHT

FIGURE A3.5

TOE DRAIN CLOSURE AND HOLDING POND DECOMMISSIONING FLOW CHART, BODO CANYON, COLORADO, SITE 
above and below the VP layer confirmed the perched zone of saturation within the tailings (DOE, 1991).

The VP layer creating the perched condition was installed at the end of the 1987 construction season as a protective cover through the winter shutdown. The average thickness of the layer was 6 inches (15 centimeters [cm]) and consisted primarily of clay. The extent of the VP layer was estimated from an aerial photo taken during the winter shutdown and from quality assurance records made during the fall of 1987. The VP layer dipped northeast from a maximum elevation of $7070 \mathrm{ft}(2150 \mathrm{~m})$ to an elevation of 7045 $\mathrm{ft}(2147 \mathrm{~m})$ at the clean fill dike. The VP layer was encountered along the entire length of the excavation for the toe drain, from north to south (DOE, 1991).

The perched zone of saturation significantly reduced the estimated volume of drainable water within the pile. Using a saturated thickness from the top of the VP layer to the recorded phreatic surface, an estimated 2 million gal $(7,600,000 \mathrm{~L})$ of drainable water remained in the cell. A 17-well dewatering system pumped an estimated 630,000 gal $(2,400,000 \mathrm{~L})$ of water during the summer and fall of 1989 . Well points used to dewater the excavation for the toe drain trench had removed another $100,000 \mathrm{gal}(380,000 \mathrm{~L})$. Thus, once the toe drain was operational, an estimated $1,300,000 \mathrm{gal}(4,900,000 \mathrm{~L})$ of pore water would potentially drain from the cell if the drain remained open indefinitely (DOE, 1991). The flow rate from the toe drain has been recorded at fairly regular intervals since its opening in November 1989, and approximately 2 million gal $(7,600,000 \mathrm{~L})$ of pore water were treated and discharged from the holding pond through the fall of 1993. In addition, an estimated $325,000 \mathrm{gal}(1,230,000 \mathrm{~L})$ of pore water evaporated from the pond, based on an evaporation rate of 42 inches $(107 \mathrm{~cm})$ per year and an average precipitation rate of 19 inches $(48 \mathrm{~cm})$ per year. Therefore, an estimated $2,300,000 \mathrm{gal}$ $(8,700,000 \mathrm{~L})$ of water were drained from the cell up to the fall of 1993 .

Currently, drained water is retained in the holding pond and is treated approximately every 6 months before discharge into the north arroyo, some 150 yards $(140 \mathrm{~m})$ northeast of the site. Lime is added to the water to precipitate the dissolved solids, metals, and uranium, which then settle out as a sludge on the bottom of the pond. Sulfuric acid is applied to the remaining water, to return the pond to an acceptable $\mathrm{pH}$ balance. Pond samples are tested to ensure the treated water is within National Pollutant Discharge Elimination System discharge limits. When the laboratory report shows the water is safe for discharge, the water is siphoned into the north arroyo through a polyvinyl chloride (PVC) outlet line.

Models developed using the drainage properties of the tailings and conditions at the site predicted flow from the toe drain would continue for a period of up to 10 years from the initial opening of the drain (TAC, 1990).

In 1992 a review of the records for water from the toe drain revealed that more water had drained out of the pile than had been predicted in 1989. A new calculation was performed in 1994 to determine the original quantity of drainable water in the pile. This calculation found the original estimate of 2 million gal ( 8 million $L$ ) of drainable water calculated in 1989 was 2 to 4 million gal ( 8 to 15 million L) too low, because the original estimate did not include drainable water from the unsaturated soil layers. Consequently an estimated 2 to 4 million gal ( 8 to 15 million $L$ ) of water remained to be drained as of the fall of 1994 . 
In 1993 and 1994 the Technical Assistance Contractor (TAC) modeled the cell drainage and reevaluated the maximum height to which the perched water could rise without causing seeps from the cell and without affecting slope stability. This analysis revealed that a perched water elevation of $7055 \mathrm{ft}(2150 \mathrm{~m})$ above mean sea level (MSL) would be acceptable.

In 1993 the TAC installed data loggers in monitor wells close to the toe drain trench and the drain to observe the rate of rise in the water level in the tailings when the toe drain was shut off. The data loggers also were used to determine if there was any seasonal recharge through the pile cover. Water level changes monitored in the toe drain with the drain shut off showed no seasonal change in water levels attributable to water entering the pile from the cover. In addition pile settlement plate elevations indicated that only very low settlements have occurred and that there is no concern about cover cracking as a result of differential settlement. These low measured cover settlements and the 1994 estimate of drainable water should alleviate concerns that transient flow from the toe drain indicates poor pile performance.

Finally a third model run was made in 1995 using the 1994 drainable water quantities. This model indicated the toe drain should be operated until 1997 to achieve an equilibrium water level at $7055 \mathrm{ft}(2150 \mathrm{~m})$ elevation. Equilibration will allow the toe drain to be closed permanently. 


\subsection{CONTAMINANT CHARACTERIZATION}

Contaminant characterization of the precipitated sludge and pond water is of primary importance to the decision-making process for decommissioning the holding pond. Samples were analyzed from the pond water, sludge retained on a Buchner funnel, and filtrate from sludge dewatering. Reviewing the chemical analyses of the sludge and of the pond water samples resulted in the following conclusions (TAC, 1992):

- The sludge would not be classified as a Resource Conservation and Recovery Act (RCRA) hazardous waste because no samples exceeded the maximum toxicity concentration levels based on the toxicity characteristic leaching procedure (42 USC $\$ 6901$ et seq.).

- The mean total radioactivity of the sludge samples was less than the 2000 picocuries per gram $(\mathrm{pCi} / \mathrm{g})$ limit that classifies shipments as radioactive hazardous material according to U.S. Department of Transportation (DOT) hazardous material regulations.

- Concentrations of organic constituents were below detection limits.

- Inorganic constituents were within the holding pond discharge limitations in the discharge permit issued by the state of Colorado.

- The maximum concentration limits (MCL) of U.S. Environmental Protection Agency (EPA) ground water standards were exceeded for molybdenum, selenium, uranium, and gross alpha from the filtrate and pond water sampled (40 CFR Part 192). Arsenic exceeded its MCL in some of the filtrate samples. Sulfate was high in both waters, with concentrations greater than 1600 milligrams per liter (mg/L).

- The high sulfide concentrations indicate the oxidation-reduction potential is reducing. Thus, if the sludge became oxidized, the molybdenum, uranium, and vanadium could be mobilized with solution concentrations exceeding those measured from the samples themselves.

This characterization has been consistent for two different sampling periods (TAC, 1992; MK-E, 1993). The potential for significant changes in the contaminant characterization of the sludge and holding pond water is small, except for possible seasonal fluctuations caused by equilibrium conditions predominant over time, and the flow continues to decrease. However, a final sampling round will be conducted before pond closure. The sludge will be analyzed to confirm that the characteristics have not changed, and to ensure that the proper administrative and regulatory decisions are made for final disposal.

These characteristics will allow shipping the sludge and holding pond liner in bulk, without triggering DOT hazardous material restrictions. The current DOT Exemption 10594 for shipping low-level radioactive mill tailings and materials contaminated with radionuclides from these tailings would apply to sludges that exceed $2000 \mathrm{pCi} / \mathrm{g}$. Further, the U.S. Nuclear Regulatory Commission (NRC) classifies the sludge as a residual radioactive 
material (RRM), which requires that the sludge be disposed of in a facility that provides perpetual care under long-term licensing agreements with the NRC (MK-E, 1991). Title I and Title II sites licensed by the NRC under 10 CFR Part 40 qualify as facilities that may receive the sludge for permanent disposal. U.S. Department of Energy (DOE) Order 5820.2A, Radioactive Waste Management, allows small quantities of RRM to be disposed of as low-level radioactive waste.

\section{$2.1 \quad$ SLUDGE DISPOSAL ALTERNATIVES}

Various alternatives may be available for disposal of the sludge, liner, and contaminated soil when the administrative decision is made to decommission the toe drain and holding pond. At that time, the following locations most probably will be available to receive the holding pond contaminated materials:

- A Uranium Mill Tailings Remedial Action (UMTRA) Project disposal cell still open.

- A Title II site still open.

- A commercial radioactive waste disposal facility (such as the Envirocare site at Clive, Utah).

- A regional compact repository licensed under 10 CFR Part 61.

- A DOE low-level waste disposal site.

- 40 CFR Part 192 remediation.

Each option is discussed below, with the conditions and restrictions that may be in effect when the toe drain and holding pond are decommissioned.

\subsubsection{UMTRA Project disposal cell}

The Cheney disposal cell near Grand Junction, Colorado, is capable of receiving 500,000 cubic yards $\left(\mathrm{yd}^{3}\right)\left(380,000\right.$ cubic meters $\left.\left[\mathrm{m}^{3}\right]\right)$ of VP materials until at least 1998. This is the UMTRA Project site most likely to be open to receive the Bodo Canyon sludge. All other sites in Colorado are scheduled for completion well before closure of the Cheney disposal cell. One possible restriction to using the Cheney cell as the repository for the sludge is the Mesa County Conditional Use Permit, which precludes the disposal of out-of-county material. Negotiations would need to be initiated with Mesa County to gain an exclusion to this restriction for the Bodo Canyon contaminated materials.

\subsubsection{Title II sites}

If the Cheney disposal cell or any other UMTRA Project disposal cell cannot receive the sludge, Title II sites may be acceptable repositories because they are perpetual care facilities licensed under 10 CFR Part 40 . The closest site is the 
Union Carbide Corporation (Umetco) site at Uravan, Colorado. However, potential Comprehensive Environmental Response, Compensation, and Liability Act (CERCLA) liability concerns must be resolved before this site could be pursued as the receptor of the sludge (42 USC $\$ 9601$ et seq.). Other Title II sites without potential CERCLA liability may be more likely options; however, transportation costs would be higher.

\subsubsection{Commercial radioactive waste disposal facility}

The Envirocare site at Clive, Utah, may qualify as an acceptable repository for the Bodo Canyon contaminated materials. Along with other commercial radioactive waste disposal facilities licensed under 10 CFR Part 61, the Envirocare site has the necessary long-term requirements for stability and institutional controls. This site can accept radioactive materials with less than $2000 \mathrm{pCi} / \mathrm{g}$; the mean total activity of the sludge is within this limit, as indicated by the most recent sampling and analysis activities (TAC, 1992; MK-E, 1993).

\subsubsection{Regional compact repository}

Except for Envirocare, commercial disposal facilities currently in operation are likely to be closed and replaced by regional compact repositories by the time the toe drain and holding pond are decommissioned. These facilities are being developed to accept civilian low-level radioactive waste and may be operating by the time the holding pond is decommissioned. Because none of these sites is operational, potential waste acceptance restrictions are not known. Minimum requirements the NRC identified for these sites in 10 CFR $\$ 61.56$ would not preclude the acceptance of contaminated materials from the holding pond as it has been characterized to date.

\subsubsection{DOE low-level waste disposal site}

The Nevada Test Site or the Idaho National Engineering Laboratory are DOE facilities that may receive low-level radioactive waste from the holding pond. DOE Order $5820.2 \mathrm{~A}$ identifies the minimum waste acceptance criteria for DOE low-level waste disposal sites. Individual DOE facilities and state regulators may have site-specific acceptance criteria that would require the UMTRA Project to apply for a special exemption. For example, the Nevada Test Site accepts only radioactive and mixed waste from DOE defense programs.

\subsubsection{CFR Part 192 remediation}

If none of the alternative sites above is able to receive the sludge and contaminated materials from the holding pond, an on-site remediation plan will be implemented under EPA regulations (40 CFR Part 192). A small containment cell that meets these standards will be engineered and constructed within the boundary of the disposal site, so that long-term surveillance of the small cell is conducted in conjunction with long-term surveillance of the main disposal cell. 


\subsection{PREPARING SLUDGE FOR SHIPMENT}

The volume of sludge to be shipped is dependent on the duration and rate at which the pore water continues to drain from the cell. An estimated $44 \mathrm{yd}^{3}$ $\left(34 \mathrm{~m}^{3}\right)$ of sludge (of which 85 to 90 percent is water) was precipitated out during the first year of operation (MK-E, 1991). Because the toe drain flow rate is decreasing, it may be reasonable to estimate that $40 \mathrm{yd}^{3}\left(30 \mathrm{~m}^{3}\right)$ of sludge is deposited per year over the service life of the holding pond. Assuming a 10-year total operating life of the pond, approximately $400 \mathrm{yd}^{3}\left(300 \mathrm{~m}^{3}\right)$ of sludge could be dewatered and shipped to the selected permanent repository.

The sludge will be dewatered on the site. The filtrate water would be contained and analyzed for compliance with the discharge permit in effect at that time. If necessary, the filtrate will be retreated before discharge into the arroyo.

Assuming the volume of the dried sludge is 30 percent of the wet volume, approximately $120 \mathrm{yd}^{3}\left(90 \mathrm{~m}^{3}\right)$ of dried sludge could be transported at the end of 10 years.

The dewatered sludge will be reanalyzed for toxicity characteristics and for total activity to confirm its suitability for shipment as a nonhazardous material and to maintain its RRM status. Analysis of the dewatered sludge is not expected to show significant variation from analyses performed to date.

If the sludge is classified as expected, the dried sludge can be hauled to the permanent repository. The high density polyethylene liner will be cut into sections that may be hauled with the sludge. After the liner is removed from the holding basin, the exposed subgrade soil will be inspected for any signs of leakage and spillage. Upon removal and shipment of the contaminated material, a radiological verification survey of the holding pond area will be conducted to confirm removal of contamination to within the allowable RRM standard as defined in 40 CFR \$192.12. Soil samples will also be analyzed for toxicity characteristic of organic and inorganic contaminants. Any soil that does not meet the standards for activity or toxicity will be removed and shipped to a designated permanent repository site.

If the facility accepting the sludge requires toxicity and/or radiological reduction, the sludge could be processed through solidification technology using Portland cement or fly ash. The high-efficiency solids contractor will produce a uniform mixture of cement, sludge, and water that will be transferred to a permanent mold for curing the mass. The mold also will serve as the container for shipment. After the mixture sets up, it will be tested for physical integrity and chemical stability before shipment.

\subsection{TRANSPORTING SLUDGE AND CONTAMINATED MATERIALS}

Current characterization data indicate the sludge and related contaminated material will not need to be shipped as hazardous material. The mean total activity of the dried or processed sludge and related materials is expected to be 
less than $2000 \mathrm{pCi} / \mathrm{g}$. As transported material it will not require classification as radioactive hazardous material, according to DOT regulations, and restrictions or special precautions will not be required to transport the contaminated material from the holding pond, except as covered by normal federal and state transportation regulations. If the activity of the sludge and contaminated materials exceeds $2000 \mathrm{pCi} / \mathrm{g}$, they will be shipped under DOT Exemption 10594 for shipping low-level radioactive mill tailings, as material contaminated with radionuclides from the tailings.

The contaminated materials will be hauled in vehicles that prevent spillage along the haul route. Haulers will be fully enclosed so that material will not be stripped from the vehicle during transport. Before leaving the loading area, the haulers will be inspected for any contaminated material that may have spilled on the exterior of the vehicle during loading. All such material will be removed and that area of the vehicle will be washed down. Wash-down water will be contained and, if necessary, treated with filtrate water from the sludge dewatering process. At the receiving repository, the vehicle will undergo decontamination requirements as established by the receiving facility. 



\subsection{TOE DRAIN CLOSURE}

The toe drain will be permanently closed when it has been determined that the remaining volume of drainable pore water from the cell will not develop unacceptable hydrostatic pressures within the cell or produce seepage at the cell boundary. In 1994 and 1995 the TAC modeled the drainage, determining it would take 2 to 4 years for the water draining from the tailings to reach equilibration at $7055 \mathrm{ft}(2150 \mathrm{~m})$ above MSL. Based on this information, the drain should be closed between 1997 and 1999. A 6-month waiting period after the initial closing of the drain will be needed to confirm that the steady-state phreatic surface of the pore water within the tailings pile is below the elevation of $7055 \mathrm{ft}$ $(2150 \mathrm{~m})$. If the phreatic surface rises above this level within the 6-month waiting period or has not achieved a steady-state condition, the drain will be reopened and the drainage/treatment cycle will continue until maximum steady-state conditions are met. To permanently seal the drain after closing the valve, the valve box will be sealed with a bentonite plug and the outlet of the PVC drain into the holding pond will be cut to belowgrade. The outlet pipe then will be packed with bentonite and the end of the pipe will be encased in concrete. The vent pipes at the valve box and at the upper southern end of the drain in the disposal cell slope will be cut to $2 \mathrm{ft}(0.6 \mathrm{~m})$ below existing grade; the top of each stem then will be capped and sealed and the surface areas around the vent pipes will be restored to their original conditions.

\subsection{SITE RESTORATION}

After all sludge and contaminated materials are removed from the holding pond area of the disposal site, the remaining soil berm of the holding pond will be regraded to permit proper drainage and to minimize the development of high velocity or concentrated flows. The holding pond site receives sheet flow runoff from the northeast face of the disposal cell and will be regraded to allow the sheet flow to drain naturally to the north and east, into the adjacent arroyo and outfall structure of ditch no. 1. Specifications require compacting the fill material to 90 percent Standard Proctor Density (American Society for Testing and Materials [ASTM] D698) (ASTM, 1988).

When the area is regraded, erosion protection measures will be implemented. Primarily, the disturbed areas will be seeded with a specified hydromulch solution to promote rapid development of a native grass cover. The hydromulch specification will be identical to that used during the remedial action of the disposal cell and processing site. If it is required by engineering calculations, durable riprap will be placed to prevent gullying of outfall drainage from the restored site.

\subsection{NRC APPROVAL}

The NRC will perform a final site inspection of the restored site. When all issues regarding the restoration are resolved to the satisfaction of the NRC, NRC administrative approval will be recorded and the restored site will fall under the long-term surveillance program of the Bodo Canyon disposal site. 



\subsection{REFERENCES}

ASTM (American Society for Testing and Materials), 1988. Annual Book of ASTM Standards, Geotextiles, Standard D 698-78, Method A, "Standard Test Methods for Moisture-Density Relations of Soils and Soil-Aggregate Mixtures Using 4.4-Ib (2.49-kg) Rammer and 12-in (305-mm) Drop," Volume 04.08, American Society for Testing Materials, Philadelphia, Pennsylvania.

DOE (U.S. Department of Energy), 1991. Remedial Action Plan and Site Design for Stabilization of the Inactive Uranium Mill Tailings Site at Durango, Colorado, UMTRA-DOE/AL-050503.0000, prepared by the U.S. Department of Energy, UMTRA Project Office, Albuquerque Operations Office, Albuquerque, New Mexico.

MK-E (Morrison Knudsen-Engineers, Inc.), 1993. "Durango Seep Water Sludge Analysis," MK-E 3885-DUR-I-01-05094-01, available at the DOE Project Office, Albuquerque Operations Office, Albuquerque, New Mexico.

MK-E (Morrison Knudsen-Engineers, Inc.), 1991. "Toe Drain Pond Operation and Decommissioning," MK-E Letter Number 91-3050-B02, available at the DOE Project Office, Albuquerque Operations Office, Albuquerque, New Mexico.

TAC (Technical Assistance Contractor), 1992. "TAC Action Memo \#378; Results of Sludge Analyses," Jacobs Engineering Group Inc., JEGA/UMT/1192-0637, available at the DOE UMTRA Project Office, Albuquerque Operations Office, Albuquerque, New Mexico.

TAC (Technical Assistance Contractor), 1990. "Modeling of Transient Drainage," Jacobs Engineering Group Inc., Calculation Number DUR-09-90-12-01-00, available at the DOE UMTRA Project Office, Albuquerque Operations Office, Albuquerque, New Mexico.

\section{DOE ORDERS}

Order 5820.2A, Radioactive Waste Management, 26 September 1988, U.S. Department of Energy, Washington, D.C., UMTRA Project Office, Albuquerque Operations Office, Albuquerque, New Mexico.

\section{CODES OF FEDERAL REGULATIONS}

10 CFR Part 40, Domestic Licensing of Source Material, U.S. Nuclear Regulatory Commission.

10 CFR Part 61, Licensing Requirements for Land Disposal of Radioactive Waste, U.S. Nuclear Regulatory Commission. 
40 CFR Part 192, Health and Environmental Protection Standards for Uranium and Thorium Mill Tailings, U.S. Environmental Protection Agency.

\section{UNITED STATE CODES}

42 USC $\$ 6901$ et seq., Resource Conservation and Recovery Act, 21 October 1976.

42 USC $\$ 9601$ et seq., Comprehensive Environmental Response, Compensation, and Liability Act, 11 December 1990. 
ATTACHMENT 4

BODO CANYON TOE DRAIN POND DISCHARGE PERMIT MANAGEMENT PLAN 



\section{PART I}

Page 11

Permit No.: CO-0041548

\section{SPECIAL REQUTREMENTS}

\section{Best Management Practices}

Best Management Practices for this facility shall include, but not be limited to, those practices within the control of the permittee and approved by the Division, which are the most effective and practicable means of preventing or reducing the amount of pollution generated by runoff and other sources intercepted and collected for discharge through outfall 004. Management practices shall be followed to ensure that the no discharge design basis is maintained and that any discharges are reduced to minimal impact and minimal frequency. Records pertaining to Best Management Practices should be kept in a log. The continudition of such practices shall include:

a. Daily check of levels in any basins and ponds and operation of any water pump(s), including water level readings in the ponds at least on a weekly basis;

b. Maintain at least a two foot freeboard level in the basins and ponds;

c. Manage water levels in the basins and ponds so that there is an adequate prevention for any potential overflow or bypasses, and to ensure that the maximum degree of treatment is maintained;

d. Maintain facilities in good working condition to ensure a minimal pollution impact into the basins, ponds, and any surface waters;

e. Ensure that no hazardous, toxic, and/or septic waste is allowed to enter the basins and ponds;

f. Daily to weekly inspection of all basins and ponds. Check for dike erosion, rodent holes, and leaks or breaks in dikes and/or liners. Note any damage and perform any needed repairs;

g. Annual weed clearing along the dikes, pond dredging on an as needed basis, and any other good housekeeping practices which are pecessary;

b. Maintain compliance with the conditions of the Remedial Action Plan for the facility;

i. Properly operate and manage the facility so that spills are prevented and materials are contained;

j. Ensure that adequate security measures continue to be practiced at the facility;

k. Ensure that the handling, storage and disposal of any toxic and/or hazardous materials on the site is properly being accomplished in compliance with any applicable federal and state requirements;

1. Ensure that materials are compatible with treatment processes, that incompatible materials do not interfere with treatment and storage processes, and that safety, health, and fire hazard prevention measures are practiced;

m. Properly operate and manage the portable wastewater treatment facility at its maximum treatment capability.

These practices may be modified or expanded to include other practices appropriate for pollution control depending on the aature of the effluent streams contributing to the discharge. 

ATTACHMENT 5

SITE INSPECTION PHOTO LOG 



\section{SITE INSPECTION PHOTO LOG}

Site: Site Activity:

Date: Time of Day: From to

Weather Conditions:

Roll Number: Film Type: Number of Exposures

Photo Number Location (Azimuth ${ }^{\mathrm{a}}$ )

Description

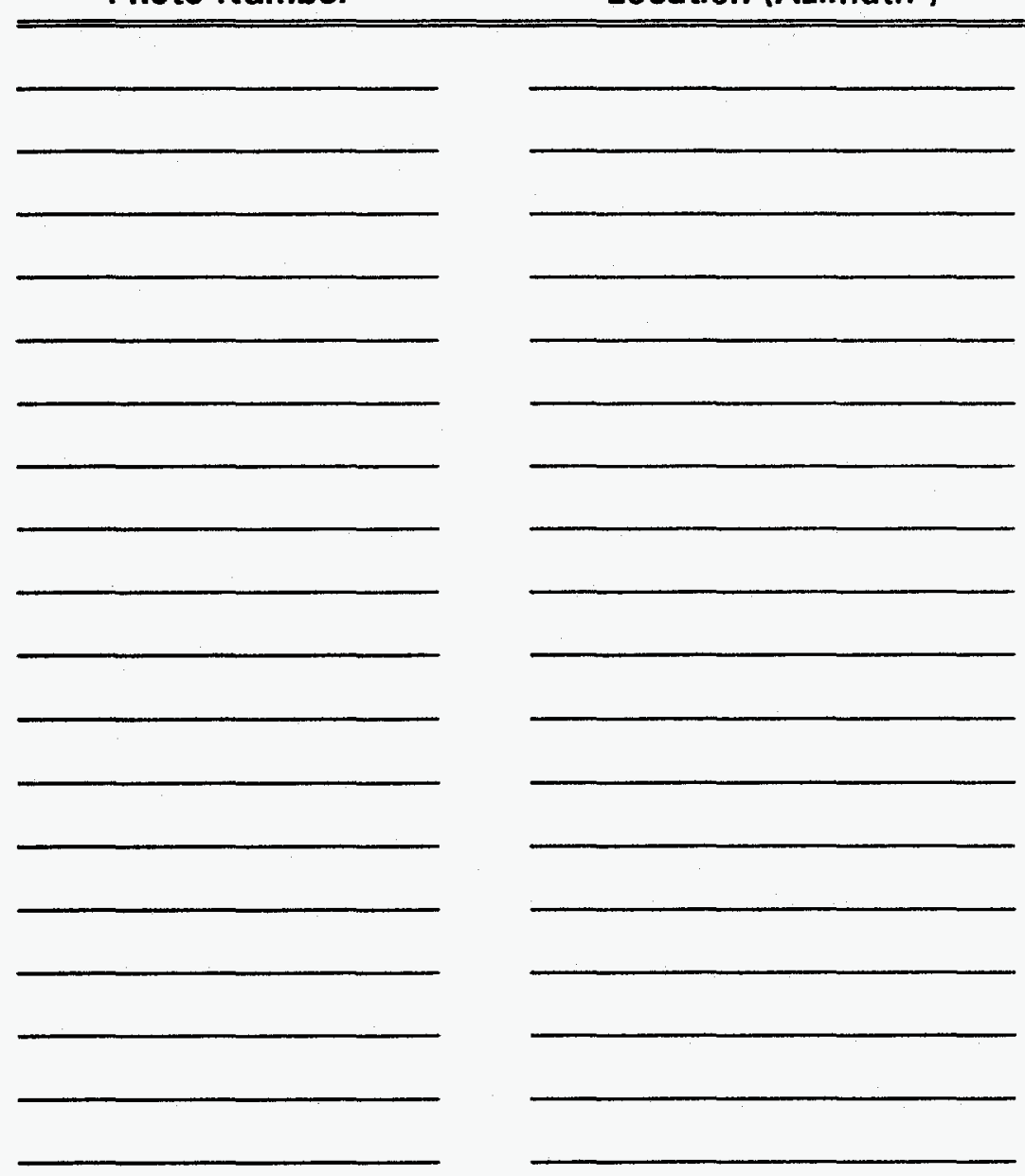

Photographer:

$$
\text { Printed Name }
$$

Declination angle: 14.7 degrees east of true north. 
ATTACHMENT 6

INITIAL SITE INSPECTION CHECKLIST 



\section{INITIAL SITE INSPECTION CHECKLIST FOR THE BODO CANYON DISPOSAL SITE}

Date of Last Inspection: Reason for Last Inspection:

Responsible Agency*: U.S Department of Energy (DOE), Grand Junction Projects Office (GJPO)

Address: P.O. Box 2567, Grand Junction, Colorado 81502-2567

Responsible Agency Official:

Inspection Start Date and Time:

Weather Conditions at Site:

Inspection Completion Date and Time:

Chief Inspector:

Name

Assistant Inspector:
Title

Organization
Title
Organization

\section{A. GENERAL INSTRUCTIONS}

1. All checklist items must be completed, and detailed comments made, to document the results of the site inspection. The completed checklist will be incorporated as part of the field record of the inspection. Additional pages should be used, as necessary, to ensure that a complete record is made, and should be numbered and attached upon completion of the inspection.

2. Inspectors are to provide an up-to-date résumé or vitae for inclusion in the inspection report.

3. Any checklist line item that is checked by an inspector must be fully explained or an appropriate reference to previous reports provided. The purpose of this requirement is to provide a written explanation of the inspector's observations and rationale for conclusions and recommendations. Explanations are to be placed on additional attachments and cross-referenced appropriately. Explanations, in addition to a narrative, will take the form of sketches, measurements, and annotated site atlas overlays.

\footnotetext{
"Responsibility for site inspections assigned by DOE UMTRA Project Office, Albuquerque, to DOE GJPO,
} November 6, 1990. 
4. The site inspection will be a walking inspection of the entire site, including the perimeter and sufficient transects to inspect the entire surface and all features specifically described in this checklist. Every monument, site marker, sign, monitoring well, and settlement plate will be inspected.

5. A set of color print $35-\mathrm{mm}$ photographs is required. Sufficient photographs will be taken to compare to baseline photographs, to determine if there are any significant differences in site appearance. In addition, all anomalous features or new features (such as changes in adjacent area land use) must be photographed. A photo log entry will be made for each photograph taken.

6. Field notes taken to assist in completing this checklist will become part of the inspection record. No form is specified; the field notes must be legible and sufficiently detailed to enable review by succeeding inspectors and the responsible agency.

B. PREPARATION (to be completed prior to site visit)

1. License (includes long-term surveillance and maintenance

Yes $\quad$ No plan) reviewed.

2. Site as-built plans and base map reviewed, with copies of the following site atlas overlays obtained:

a. Adjacent off-site features and land use; fences, gates, and signs; access roads and paths.

b. Survey boundary monuments, site markers, settlement plates, aerial photo ground controls, ground photo locations.

c. Monitor wells, site drainage, diversion channels.

d. Planned inspection transects and vegetation cover.

e. Others.

These overlays will be used to identify site features and record, appropriate field data.

3. Previous inspection reports reviewed.

a. Were anomalies or trends in modifying processes detected on previous inspections?

b. Was a Phase II inspection conducted?

c. Was custodial maintenance performed? 
d. Was contingency repair work done as a result of the Phase II inspection?

4. Site custodial maintenance and contingency repair records reviewed.

a. Has site contingency repair resulted in a change from as-built conditions?

b. Are reviewed as-builts available that reflect contingency repair changes?

5. Adjacent property entry approval obtained (attach signed access agreement).

6. Aerial photos reviewed, if taken since last inspection. For each set, enter date taken, scale, and if interpreted.

$\underline{\text { Set }}$

Date

Scale

Interpreted

1.

2.

3.

7. Were any of the following suggested by examination

Yes No of aerial photographs (if yes, give photo set date and indicate if item was noted by interpreter or inspector):

a. Intrusion by man?

b. Intrusion by animals?

c. Channelized erosion on slopes?

d. Change in area drainage?

e. Landslides?

f. Creep on slopes?

g. Obstruction of diversion channels? 
h. Bank erosion of diversion channels?

i. Seepage?

j. Cracking?

k. Change in vegetative cover?

I. Displacement of fences, site markers, boundary markers, or monuments?

m. Change in adjacent land use?

n. Evidence of radioactive sands exposure or transport?

8. From as-builts or subsequent inspection reports, note distance and azimuth from designated site location, such as a monument, to adjacent off-site features that could eventually affect site integrity.

Off-site feature

Site monument no.

Distance

Azimuth

1.

2.

3.

9. Assemble and check out the following equipment, as needed, to conduct inspections:

a. Cameras, film, and miscellaneous support equipment.

b. Binoculars.

c. Tape measure.

d. Optical ranging device.

e. Brunton compass.

f. Photo scale stick.

g. Erasable board.

h. Plant press, plastic bags for vegetation.

i. Keys to locks.

j. Bolt cutters.

k. Hand lens.

I. Clipboard.

m. Others. 


\section{SITE INSPECTION}

1. Adjacent off-site features (within 0.25 mile $[0.4$ kilometer] of site boundary)

a. Have there been any changes in use of adjacent areas (grazing, construction, agriculture)?

b. Are there any new roads or trails?

c. Has there been a change in the position of nearby stream channels?

d. Has there been headward erosion of nearby gullies?

e. Are there new drainage channels?

f. Others?

2. Access roads and paths, fences, gates, and signs.

a. Is there a break in the fence?

b. Have any posts been damaged or their anchoring weakened?

c. Is there evidence of erosion or digging beneath the fence?

d. Does the gate show evidence of tampering or damage?

e. Is there any evidence of human intrusion?

f. Is there any evidence of large animal intrusion?

g. Have any signs been damaged or removed? (Number of signs replaced:

h. Are access roads and paths passable?

i. Others? 
3. Monuments and other permanent features.

a. Have the survey or boundary monuments been defaced or disturbed?

b. Have the site markers been disturbed by man or natural processes?

c. Do natural processes threaten the integrity of any monument or site marker?

d. Others?

4. Crest.

a. Is there evidence of uneven settling (depressions, scarps)?

b. Is there cracking?

c. Has the outer cover layer been breached?

d. Is there evidence of erosion?

1) By water (rills, rivulets)?

2) By wind (pedestal rocks, ripple marks)?

e. Is there evidence of animal burrowing?

f. Others?

5. Slopes.

a. Is there evidence of gradual downslope movement or creep (terraces, deflection of plants)?

b. Is there cracking?

c. Can depressions or bulges on the slope be seen?

d. Has the outer cover layer been breached? 
e. Is there evidence of erosion:

1) By water?

2) By wind?

f. Has water runoff become channelized (rivulets, gullies)?

g. Is there evidence of seepage (moisture, color, vegetation)?

h. Is there evidence of animal burrowing?

i. Is there evidence of deterioration of riprap or gravel cover?

j. Others?

6. Periphery (within site boundaries).

a. Is there evidence of seepage, such as wet areas or localized change of vegetation?

b. Is there evidence of sediment transport from the uranium mill tailings by water or wind?

c. Is the vegetative cover as described in the as-builts?

d. Is the drainage as described in the as-builts?

e. Others (burrowing animals, erosion)?

7. Diversion channels.

a. Is there evidence of bank erosion?

b. Has the integrity of riprap structures been disturbed by people or natural processes?

c. Is there evidence of channel erosion?

d. Is there evidence of sedimentation in the channel? 
e. Is the channel obstructed in any way?

f. Is there any evidence that the diversion channels are not performing their function?

g. Others?

8. Photography.

a. Have all photos required by the site atlas photo overlay been taken?

b. Has a photo log sheet been prepared for each roll of film exposed?

c. Number of rolls of film exposed:

d. Others?

9. Monitor wells.

a. Have any monitor wells been disturbed by man or natural processes?

b. Does any natural process threaten the integrity of any monitor well?

c. Are all monitor wells capped and locked?

d. Others?

\section{FIELD CONCLUSIONS}

1. Is there an imminent hazard to the integrity of the uranium mill tailings (immediate report required)?

Person:

Agency to whom report made:

2. Are more frequent Phase 1 inspections required?

3. Are existing contingency repair actions satisfactory?

4. Is a Phase II inspection required?

5. Is a contingency report or custodial maintenance required? 
6. Rationale for field conclusions are documented as the text of this report.

\section{E. CERTIFICATION}

I have conducted a prelicensing inspection of the Durango uranium mill tailings site in accordance with the procedures of the license (includes the site-surveillance plan) as recorded on this checklist, attached sheets, field notes, photo log sheets, and photos.

Chief Inspector's Signature

Printed Name

Title

Date 
ATTACHMENT 7

AGENCY NOTIFICATION AGREEMENTS 


\section{R A F T}

Dick Schirard

La Plata County Sheriff's Dept.

742 Turner Drive

Durango, CO 81301

Dear Mr. Schirard:

The U.S. Department of Energy (DOE) Uranium Mill Tailings Remedial Action Project Team is requesting notification in the event of any unusual activities or events in La Plata County, Colorado, or around the Bodo Canyon disposal site.

The purpose of the notification request is to assist the DOE in surveying and maintaining the integrity of its disposal site and to ensure public safety.

If during the course of routine activities, anything out of the ordinary is observed by your staff or reported to your office, we would appreciate notification to the DOE Grand Junction Projects Office's 24-hour phone line at (970) 248-6070. If the notification request discussed above is agreeable to you, please sign and return the attached reply letter for our records as soon as possible.

Should you have any questions, please contact me at (505) 845-4030. Thank you for your attention in this matter.

Sincerely,

J. M. Pape

DOE Project Site Manager

Environmental Restoration Division

U.S. Department of Energy

JP/jem

Enclosure

cc: w/o enclosure

S. Cox, TAC

M. Hansen, TAC

C. Jones, GJPO

J. Pape, DOE

C. Saumur, TAC

J. Virgona, GJPO

D R A F T 


\section{R A F T}

J. M. Pape

DOE Project Site Manager

Environmental Restoration Division

U.S. Department of Energy

2155 Louisiana Blvd., NE, Suite 4000

Albuquerque, NM 87110

Dear Mr. Pape:

This letter is to concur with the U.S. Department of Energy (DOE) request for notification as set forth in the DOE's letter. As requested in your letter, this office will contact the DOE's Grand Junction Projects Office at (970) 248-6070 if any unusual event or anomaly is observed or reported at the Bodo Canyon disposal site, Durango, Colorado.

Sincerely,

Dick Schirard

La Plata County Sheriff

cc: S. Cox, TAC

$M$. Hansen, TAC

C. Jones, GJPO

C. Saumur, TAC

J. Virgona, GJPO 
Jim Webb

San Juan National Forest

701 Camino Del Rio

Durango, CO 81301

Dear Mr. Webb:

The U.S. Department of Energy (DOE) Uranium Mill Tailings Remedial Action Project Team is requesting notification of any unusual activities or events in La Plata County, Colorado, or around the Bodo Canyon disposal site.

The purpose of this notification request is to assist the DOE in surveying and maintaining the integrity of its disposal site and to ensure public safety.

If during the course of routine activities, anything out of the ordinary is observed by your staff or reported to your office, we would appreciate immediate notification to the DOE Grand Junction Projects Office's 24-hour phone line at (970) 248-6070. If the notification request discussed above is agreeable to you, please sign and return the enclosed reply letter for our records as soon as possible.

Should you have any questions, please contact me at (505) 845-4030. Thank you for your attention in this matter.

Sincerely,

J. M. Pape

DOE Project Site Manager

Environmental Restoration Division

U.S. Department of Energy

JP:jem

Enclosure

cc: w/o enclosure

S. Cox, TAC

M. Hansen, TAC

C. Jones, GJPO

J. Pape, DOE

C. Saumur, TAC

J. Virgona, GJPO

D R A F T 


\title{
D R A F T
}

\author{
J. M. Pape
}

DOE Project Site Manager

Environmental Restoration Division

U.S. Department of Energy

2155 Louisiana Blvd., NE, Suite 4000

Albuquerque, NM 87110

Dear Mr. Pape:

This letter is to concur with the U.S. Department of Energy (DOE) request for notification as set forth in the DOE's letter. As requested in your letter, this office will contact the Grand Junction Projects Office at (970) 248-6070 if any unusual event or anomaly is observed or reported at the Bodo Canyon disposal site, Durango, Colorado.

Sincerely,

Mr. Jim Webb

San Juan National Forest Ranger

cc: S. Cox, TAC

M. Hansen, TAC

C. Jones, GJPO

J. Pape, DOE

C. Saumur, TAC

J. Virgona, GJPO 


\section{R A F T}

Larry Mooney

Area Manager

National Weather Service Office

10230 Smith Road

Denver, Colorado 80239

Dear Mr. Mooney:

The U.S. Department of Energy (DOE) Uranium Mill Tailings Remedial Action Project Team is requesting notification in the event of issuance of flash flood or tornado warnings in La Plata County, Colorado. We would appreciate notification to the DOE Grand Junction Projects Office's 24-hour phone line at (970) 248-6070 within 8 hours of issuance of a warning or episode of warnings.

The purpose of this warning is to assist the DOE in surveying and maintaining the integrity of its disposal site located 3.5 miles (5.6 kilometers) southwest of Durango, Colorado.

If the notification request discussed above is agreeable to you, please sign and return the enclosed reply letter for our records as soon as possible.

Should you have any questions, please contact me at (505) $845-4030$.

Sincerely,

J. M. Pape

DOE Project Site Manager

Environmental Restoration Division

U.S. Department of Energy

JP:jem

Enclosure

cc: $w / o$ enclosure

S. Cox, TAC

M. Hansen, TAC

C. Jones, GJPO

J. Pape, DOE

C. Saumur, TAC

J. Virgona, GJPO

D R A F T 


\section{R A F T}

\section{J. M. Pape}

DOE Project Site Manager

Environmental Restoration Division

U.S. Department of Energy

2155 Louisiana Blvd., NE, Suite 4000

Albuquerque, NM 87110

\section{Dear Mr. Pape:}

This letter is to concur with the U.S. Department of Energy (DOE) request for notification as set forth in the DOE's letter. As requested in your letter, this office will contact the Grand Junction Projects Office at (970) 248-6070 in the event of issuance of a flash flood or tornado warning in La Plata County, Colorado.

Sincerely,

Larry Mooney

National Weather Service

cc: S. Cox, TAC

M. Hansen, TAC

C. Jones, GJPO

J. Pape, DOE

C. Saumur, TAC

J. Virgona, GJPO 
National Earthquake Information Center. World Data Center A for Seismology

Director

(B03) 236-1510

Research

(303) 236-1506
U.S. Geological Survey

Box 25046, DFC, MS-967

Denver, Colorado 80225 USA

Telex: (WUTCO) 5106014123ESL UD
Operations

(303) 236-1500

QED

(800) $358-2663$

Clinton C. Smythe

$-2-$

We have entered the following selection criteria into our notification program:

1. Any earthquake of magnitude 3.0 or greater, within 0.3 degrees (about 20 miles) of any site shown above, or

2. Any earthquake of magnitude 5.0 or greater, within 1.0 degrees (about 70 miles) of any site shown above. .

Sincerely,

Duce w. Preserve

Brice Presgrave

U.S. Geological Survey

National Earthquake Information Center

P.O. Box 25046

Mail Stop 967

Denver Federal Center

Denver, Colorado 80225

Please address future correspondence to Stuart Koyanagi at the above address. I have moved to a different project.

Thank you + best regards,

Sure Pregame

A7-8 


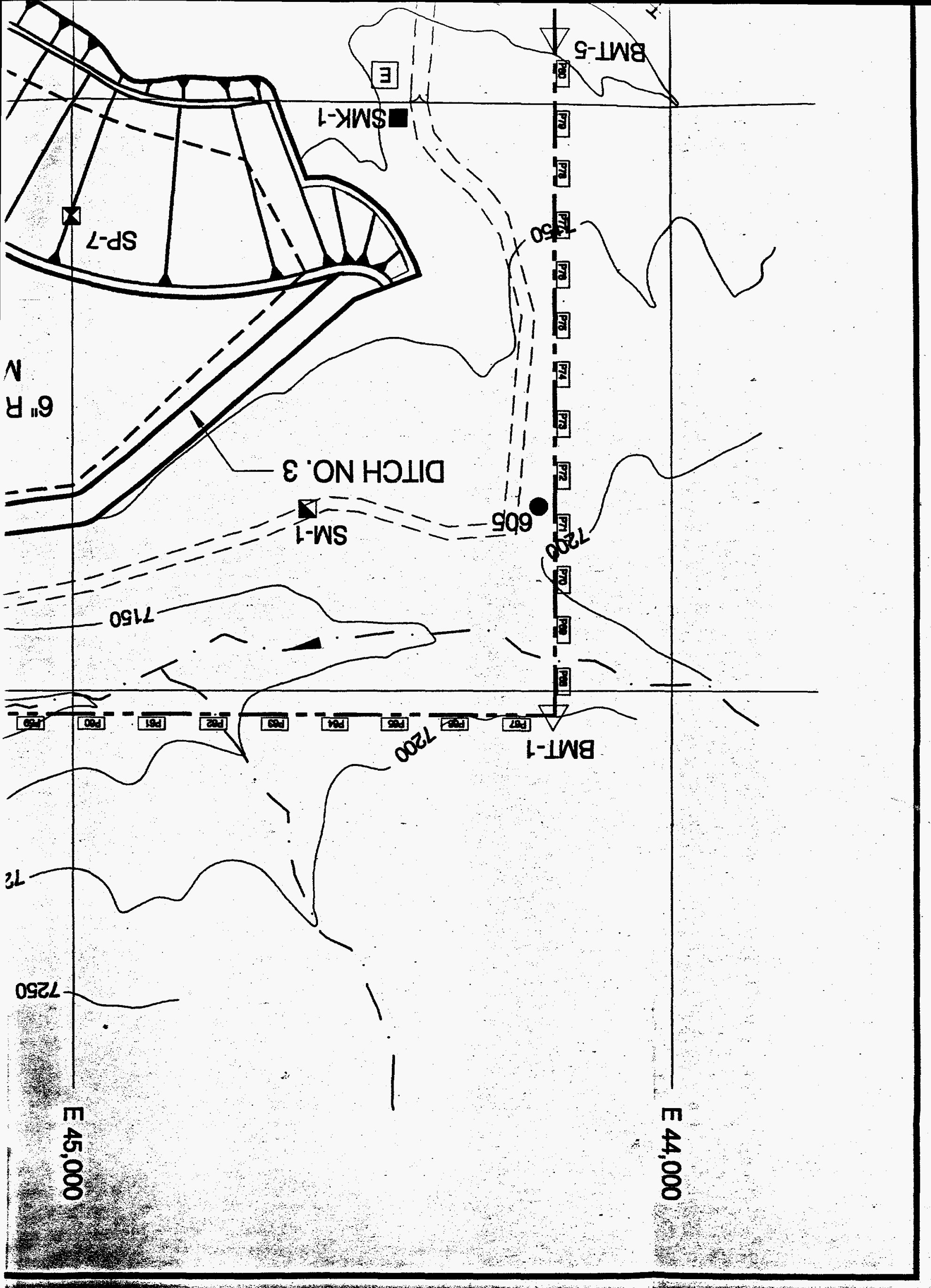




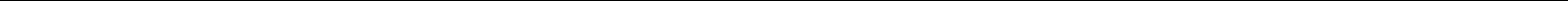




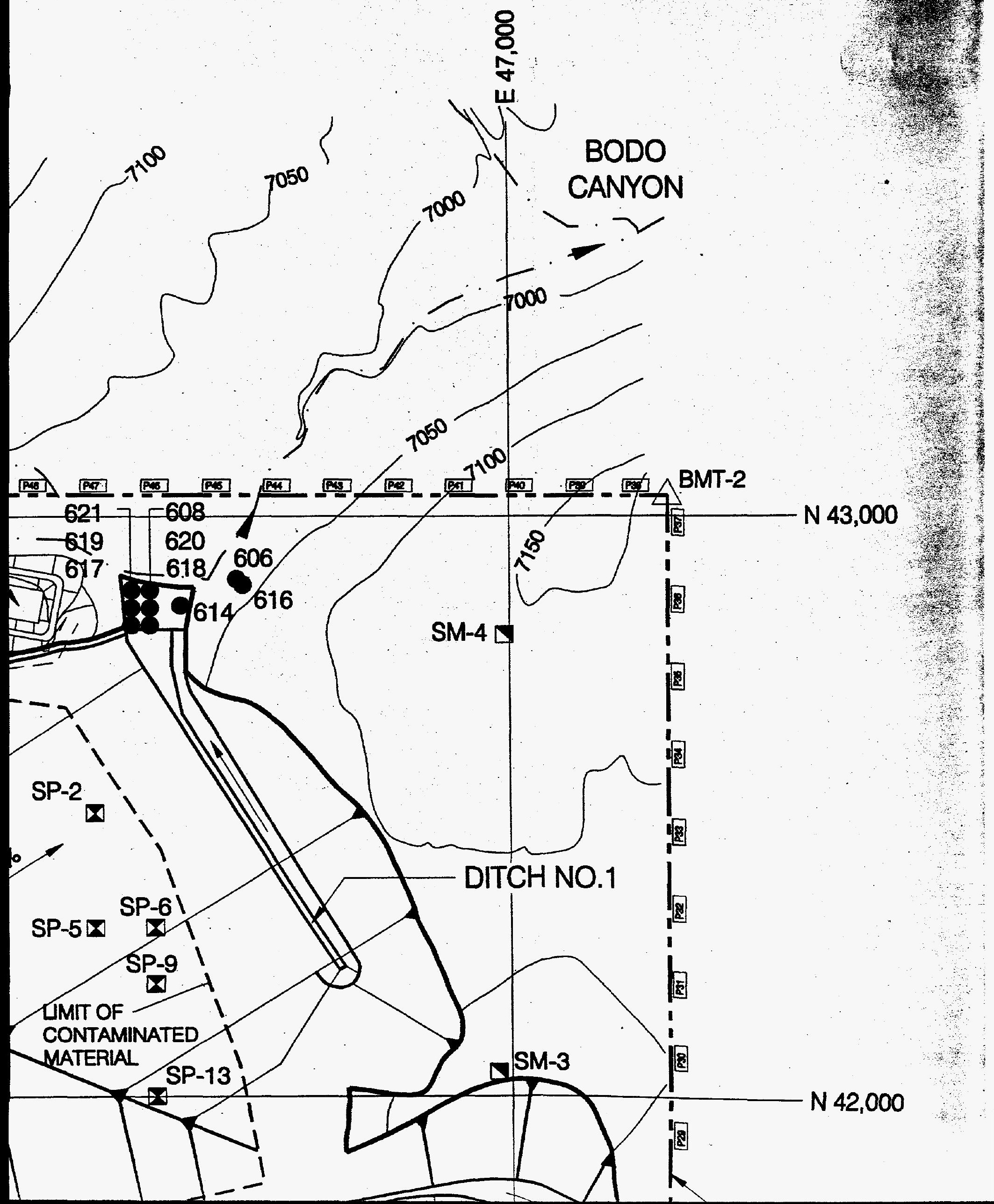


LOCATION COORDINATES FOR WELS, MONUMENTS, MARKERS AND SETTLEMENT PLATES

SURVEY MONUMENTS

\begin{tabular}{|c|c|c|c|}
\hline SYMBOL & NORTHING & EASTING & \\
\hline $8 M-1$ & N49892.34 & E44501.44 & \\
\hline $8 M-2$ & N41370.10 & $E 4587237$ & \\
\hline SM-8 & N42035.81 & E46864.05 & \\
\hline $5 M-4$ & N42804.37 & E46001.91 & \\
\hline \multicolumn{3}{|c|}{ BOUNDARY MONUMENTS } & \\
\hline SMMBOL & NORTHING & EASTING̈ & \\
\hline BMT-1 & $N 43,041.67$ & $E 44,180.57$ & \\
\hline BMT-2 & N43,041.67 & $E 47,285.57$ & \\
\hline BMT-3 & $N 41,341.67$ & $E 47,285.57$ & \\
\hline BMT-4 & $\mathrm{N} 41,341.76$ & $E 44,850.01$ & \\
\hline BMT-5 & N41,800.10 & $E 44,190.74$ & \\
\hline \multicolumn{3}{|c|}{ LOCATIONS OF MONITORING WELLS } & \\
\hline $\begin{array}{l}\text { WELLID } \\
\text { NUMBER }\end{array}$ & NORTHING & EASTING & \\
\hline DUROS-605 & N42083.8 & EA4216.4 & \\
\hline DUROS-608 & N42899.8 & E46538,4 & \\
\hline DUAOS-607 & N41375.0 & E45623.4 & \\
\hline DUAOS-608 & N42879.1 & E46374.2 & \\
\hline DURO3-811 & N41542.9 & E45994.8 & \\
\hline DUROS-612 & N41505.3 & E46165.7 & \\
\hline DUROs-614 & N42854.7 & E48445.6 & \\
\hline DUROS-616 & Ma28so.1 & E48548.9 & \\
\hline DUROS-817 & N42880.4 & E40859.8 & \\
\hline DUROS618 & N42850.6 & E46989.6 & \\
\hline DUROS-619 & Na2870.9 & EA6558.1 & \\
\hline DUROS-620 & Mes:s70.1 & $E 46371.3$ & \\
\hline DURO3-021 & M4287a.7 & E40505.2 & \\
\hline DURos-803 & Nov44.3 & E46064.6 & \\
\hline DUROs-exs & $M=017.7$ & E45808.3 & \\
\hline \multicolumn{3}{|c|}{ SETILEMENT PLATES } & \\
\hline STMBOL & NORTHING & EASTING & $\begin{array}{c}\text { ELEVATION } \\
12-6-90\end{array}$ \\
\hline$\frac{\text { SP-1 }}{\text { SP-2 }}$ & $\frac{N 42,600}{N 42,500}$ & $E 45,800$ & 7146.83 \\
\hline
\end{tabular}




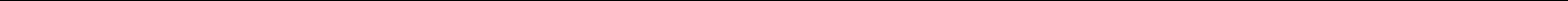


BODO CANYON DISPOSAL SITE BOUNDARY

$T-3$

\begin{tabular}{|c|c|c|c|c|}
\hline SYMBOL & NORTHING & EASTINC & 3 & $18 \quad-126$ \\
\hline SP-1 & $\mathrm{N} 42,000$ & $E A 5,800$ & 3 & Anso \\
\hline SP-2 & $\mathrm{N} 42,500$ & $E 46,300$ & $m$ & 4.5072 \\
\hline SP-3 & $N 42,300$ & $E 45,700$ & & $3-\quad 7151$ \\
\hline SP-4 & $N 42,300$ & $E 48,000$ & $\therefore \cdots$ & 867144 \\
\hline SP-5 & $N 42300$ & $E 46,300$ & $\therefore$ & 7003 \\
\hline 8P-6 & $N 42,300$ & $E 46,400$ & & 7078 \\
\hline SP-7 & $N 42,200$ & 545,000 & & 7122 \\
\hline SP-8 & $N 42,200$ & $E 45,300$ & & 7147 \\
\hline SP-9 & $N 42,200$ & $E 46,400$ & . & $\quad 7097$ \\
\hline SP-10 & $N 42,100$ & $E 46,000$ & & $\begin{array}{r}7146 \\
\end{array}$ \\
\hline SF-it & Plan,000 & $E A E_{1}, A G$ & & $28 \mathbf{7 4 2 5}$ \\
\hline SP-12 & $N 42,000$ & $E 45,700$ & & $\times 7144$ \\
\hline SP-13 & $N 42,000$ & $E 46,400$ & & $\begin{array}{r}7111 \\
\end{array}$ \\
\hline SP-14. & N41,000 & $E 46,000$ & & $\therefore 7112$ \\
\hline
\end{tabular}

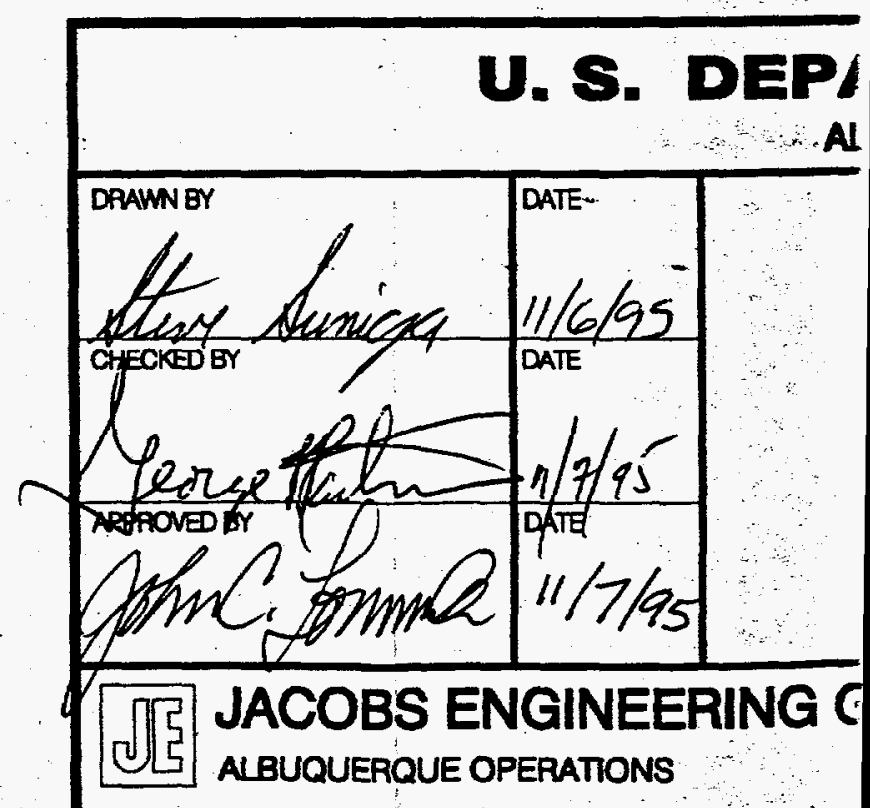




\begin{tabular}{|c|c|c|}
\hline ING & EASTING & $\begin{array}{l}\text { ELEVATION } \\
12-6-90\end{array}$ \\
\hline 10 & $E 45,800$ & 7146.83 \\
\hline 10 & $E 46,300$ & 7072.57 \\
\hline 10 & $E 45,700$ & 7151.79 \\
\hline 60 & $E 46,000$ & 7144.58 \\
\hline 00 & $E 46,300$ & 7033.95 \\
\hline 60 & $E 46,400$ & 7076.93 \\
\hline 00 & $E 45,000$ & 7122.30 \\
\hline Do. & $E 45,300$ & 7147.30 \\
\hline Do & $E 46,400$ & 7087.71 \\
\hline 30 & $E 46,000$ & 7146.88 \\
\hline 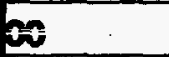 & EAE,A4G & 712565 \\
\hline $\mathbf{0}$ & $E 45,700$ & 7144.15 \\
\hline$\infty$ & $E 46,400$ & $\quad 7111.41$ \\
\hline$\infty$ & $E 46,000$ & 7112.43 \\
\hline
\end{tabular}
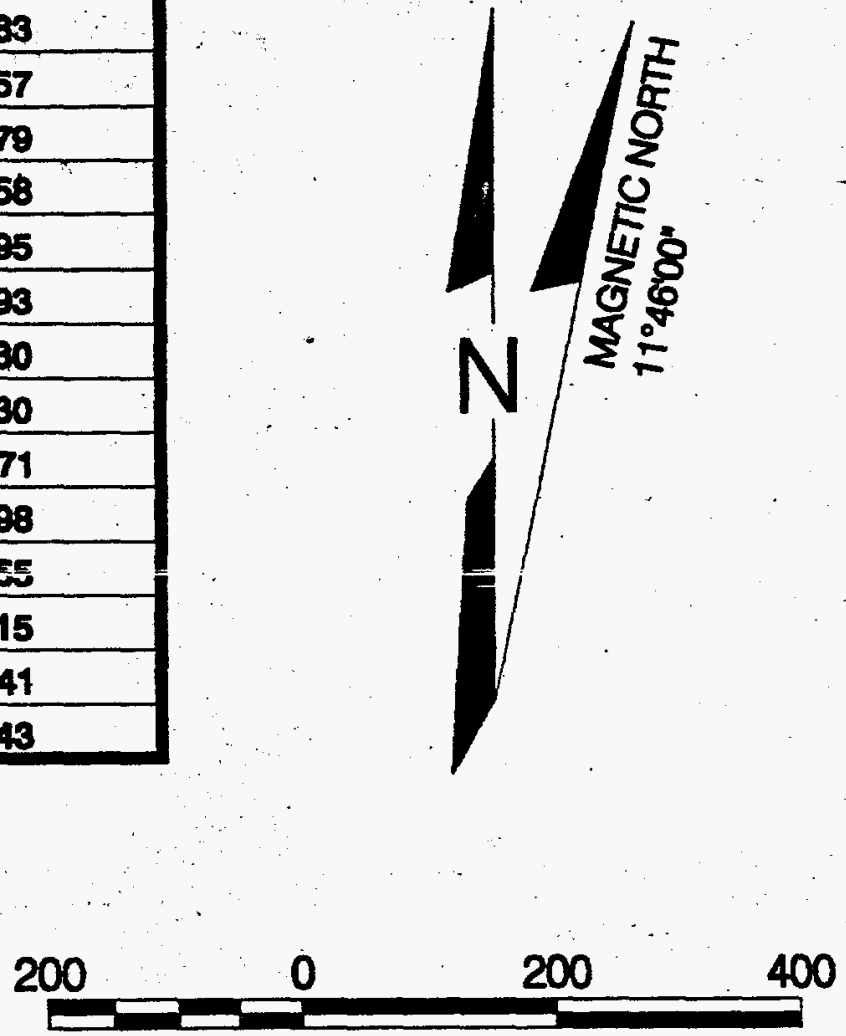

SCALE IN FEET

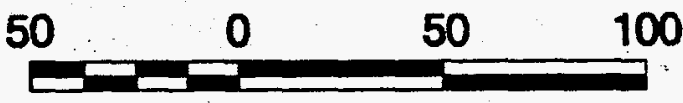

SCALE IN METERS

CONTOUR INTERVAL $=50 \mathrm{FT}$

NOTE: THIS BASE MAP COMPILED FROM DUR-PS-10-0330, DUR-PS-10-0331, AND DUR-PS-10-0337, PREPARED BY MK-FERGUSON.

\section{U. S. DEPARTMENT OF ENERGY \\ ALBUQUERQUE, NEW MEXICO}

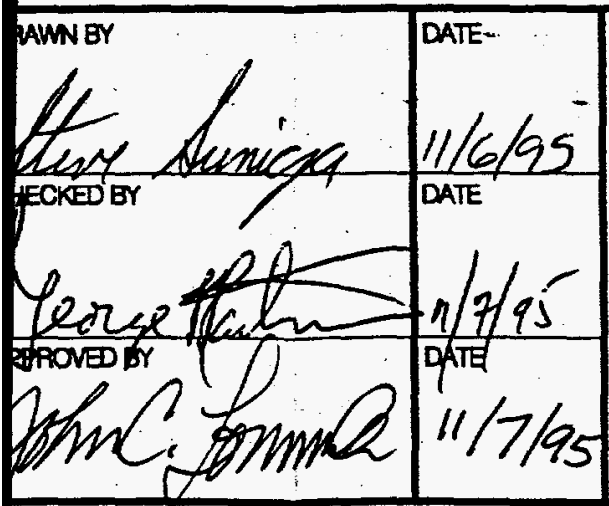

PLATE 1

LONG-TERM SURVEILLANCE PLAN

BODO CANYON DISPOSAL SITE

DURANGO, COLORADO

DISPOSAL SITE MAP

\section{JACOBS ENGINEERING GROUP \\ I5 ALBUQUERQUE OPERATIONS}

